Portland State University

PDXScholar

\title{
A Location Analysis of Vandalism to the Rock Art of the Columbia River Gorge National Scenic Area
}

Julia J. Wilt

Portland State University

Follow this and additional works at: https://pdxscholar.library.pdx.edu/open_access_etds

Part of the Geography Commons

Let us know how access to this document benefits you.

\section{Recommended Citation}

Wilt, Julia J., "A Location Analysis of Vandalism to the Rock Art of the Columbia River Gorge National Scenic Area" (1993). Dissertations and Theses. Paper 4661.

https://doi.org/10.15760/etd.6545

This Thesis is brought to you for free and open access. It has been accepted for inclusion in Dissertations and Theses by an authorized administrator of PDXScholar. Please contact us if we can make this document more accessible: pdxscholar@pdx.edu. 
AN ABSTRACT OF THE THESIS OF Julia J. Wilt for the Master of Science Degree in Geography presented May 26, 1993.

Title: A Locational Analysis of Vandalism to the Rock Art of the Columbia River Gorge National Scenic Area.

APPROVED BY THE MEMBERS OF THE THESIS COMMITTEE:
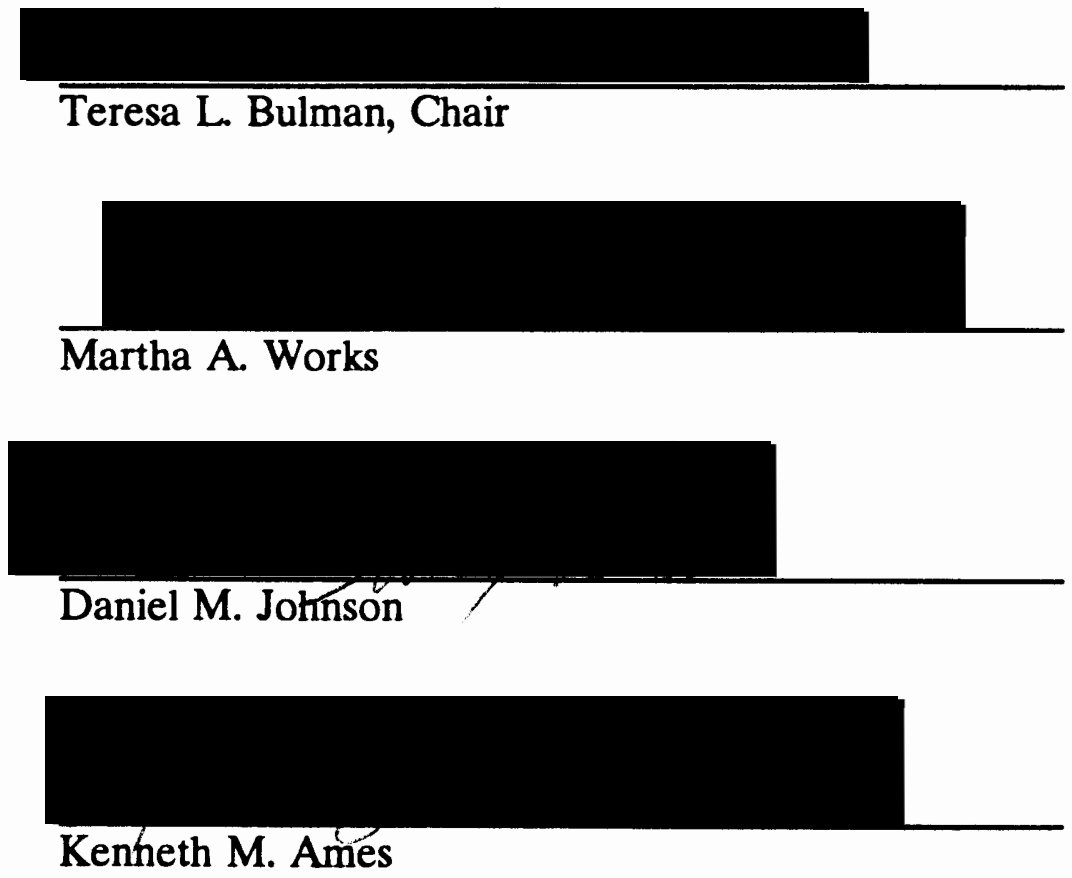

Archaeological sites in the New World are the fragile and non-renewable remains of cultures which flourished for thousands of years prior to European contact and displacement. Sites which escape the effects of erosion and development often fall victim to vandalism. Cultural resources, including rock art and other archaeological sites, are protected by state and federal laws which 
prohibit the removal or disturbance of the sites, whether from development or from vandalism. Vandalism is frequently seen as a problem for law enforcement rather than a problem for cultural resource management. Management plans which include cultural resource protection provisions and guidelines often focus on threats to cultural resources from development, and omit planning which targets vandalism.

The rock art sites of the Columbia River Gorge National Scenic Area ("Scenic Area") have been affected by developments such as The Dalles Dam and by the vandalism. In this study, the nature and degree of vandalism to the rock art sites in the Scenic Area is considered in the context of public awareness of, and access to, these sites. Rock art sites which are easily located and which have been the focus of public awareness are hypothesized to be the most severely vandalized.

To test this hypothesis, fifteen of the 44 rock art sites in the Scenic Area were selected for study, and were assessed for kind and degree of vandalism, and means and ease of access. The results of analysis yielded two statistically significant associations of variables which support the hypothesis: an association between vandalism and public awareness of sites, and an association between vandalism and the primary means of access.

The analysis suggests that public awareness is one of the most important issues which land managers must address when designing cultural resource protection plans. 


\section{A LOCATIONAL ANALYSIS OF VANDALISM TO THE ROCK ART OF THE COLUMBIA RIVER GORGE NATIONAL SCENIC AREA}

by

JULIA J. WILT

A thesis submitted in partial fulfillment of the requirements for the degree of

\section{MASTER OF SCIENCE in GEOGRAPHY}

Portland State University 1993 
TO THE OFFICE OF GRADUATE STUDIES:

The members of the Committee approve the thesis of Julia J. Wilt presented May 26, 1993.

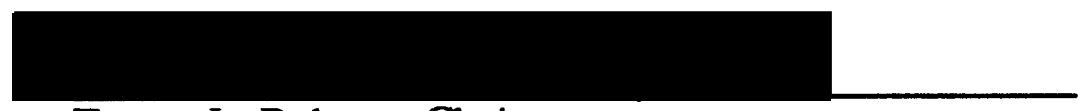

Teresa L. Bulman, Chair

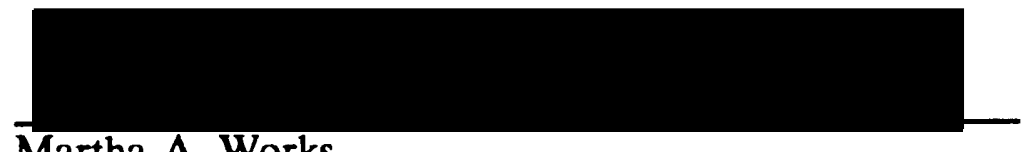

Martha A. Works
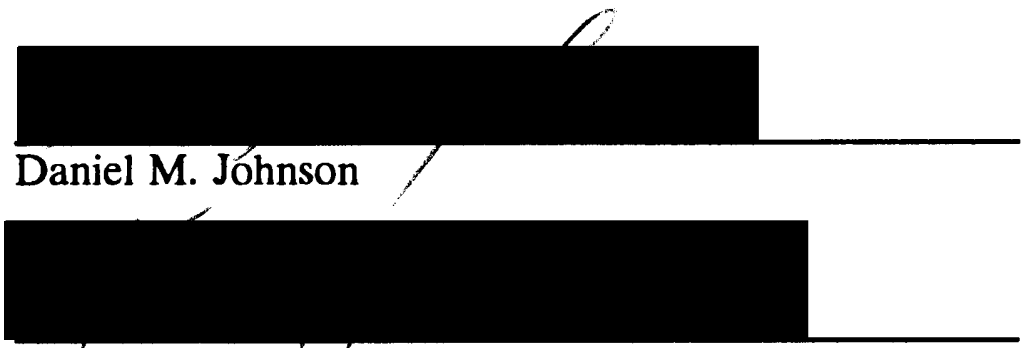

Kenneth M. Antes

\section{APPROVED:}

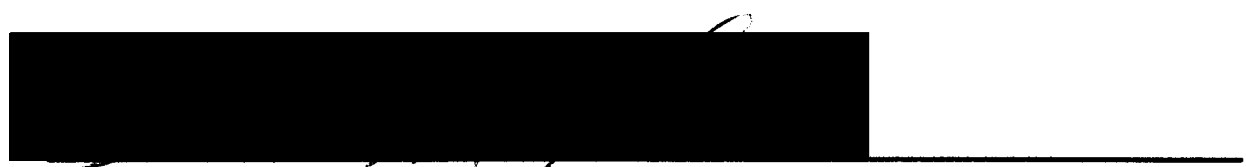

Daniel M. Johnson, Chair/Department of Geography

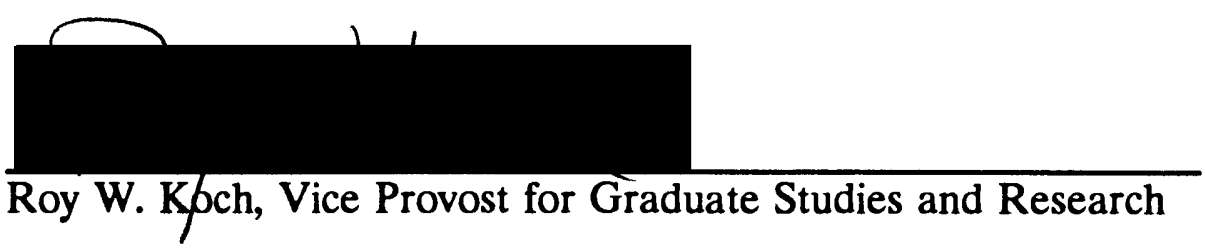




\section{ACKNOWLEDGEMENTS}

Many people provided information and assistance with this project.

Foremost among them are Dr. James Keyser, regional archaeologist in the Pacific Northwest for the Forest Service, who contributed film and processing; Rick McClure, Forest Service archaeologist in the Gifford-Pinchot National Forest, who furnished site records and other materials, as well as a copy of his own renowned master's thesis; Mike Boynton, Forest Service archaeologist in the Columbia River Gorge National Scenic Area, who spent a tremendous amount of time answering all my questions, cheerfully searching for documents, phone numbers, names, and other innumerable bits of information, as well as reviewing Chapter III and some of my maps; and Greg Bettis, who also donated time and documents, and who assisted in the location of some of the more elusive sites.

Others who contributed their time and expertise include Allen Bell at the Columbia River Gorge Commission; Rich Davis, park ranger at Horsethief Lake State Park; Dr. Robert Fountain of the Statistics Consulting Lab at Portland State University; Rob Whitlam and Sara Steel at the Office of Archaeology and Historic Preservation in Olympia, Washington; Alice Tratebas, Bureau of Land Management archaeologist at Whoopup Canyon, Wyoming; and Eric Carlson, who provided the drawing which illustrates the vandalism at Horsethief Lake State Park. 
Finally, I wish to thank members of the faculty, administration, and fellow graduate students at Portland State University: Carolyn Perry, whose friendship and technical expertise were crucial in the completion of this document; Manette Simpson, Amy Benson, and Tom Harvey, for their friendship, support, and counsel; and most importantly, my committee, particularly my advisor, Dr. Teresa Bulman. 
TABLE OF CONTENTS

PAGE

ACKNOWLEDGEMENTS $\ldots \ldots \ldots \ldots \ldots \ldots \ldots \ldots \ldots$ iii

LIST OF TABLES $\ldots \ldots \ldots \ldots \ldots \ldots \ldots \ldots \ldots \ldots \ldots \ldots \ldots \ldots$ vii

LIST OF FIGURES $\ldots \ldots \ldots \ldots \ldots \ldots \ldots \ldots \ldots$ viii

CHAPTER

I INTRODUCTION $\ldots \ldots \ldots \ldots \ldots \ldots \ldots \ldots \ldots \ldots \ldots$

II LITERATURE REVIEW $\ldots \ldots \ldots \ldots \ldots \ldots \ldots \ldots \ldots$

III LOCATION AND DESCRIPTION OF THE STUDY AREA . . . 19

Geology and Physiography of the Gorge ......... 21

Climate and Vegetation of the Scenic Area ....... 26

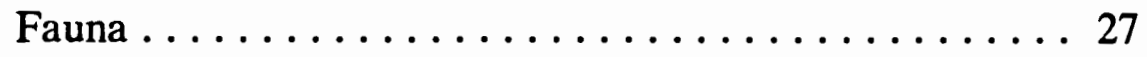

Prehistory . . . . . . . . . . . . . . . 29

Rock Art of the Gorge .............. 37

Euro-American Contact and Settlement .........41

IV LAND OWNERSHIP AND MANAGEMENT . . . . . 47

Current Status of the Rock Art as a Cultural Resource . . 54

V METHODOLOGY ................... 70

Data Collection ................. 73

Data Analysis . . . . . . . . . . . . 76 
PAGE

Data Limitations . . . . . . . . . . . . . . 81

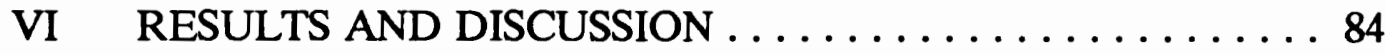

Management and Policy Implications . . . . . . . . 102

VII CONCLUSIONS $\ldots \ldots \ldots \ldots \ldots \ldots \ldots \ldots \ldots \ldots \ldots \ldots \ldots$

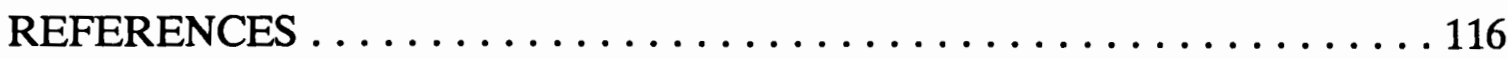
APPENDICES

A THE 15 ROCK ART SITES SELECTED FOR THE STUDY OF VANDALISM IN THE COLUMBIA RIVER GORGE NATIONAL SCENIC AREA AND THEIR RELATIONSHIP TO THE VARIABLES AFFECTING VANDALISM . . . . . . . . . . . . . . . . . . . . 124

B THE RESULTS OF THE STATISTICAL ANALYSIS . . . . . 127 


\section{LIST OF TABLES}

TABLE

PAGE

I Cultural Stages and Associated Sites in the Columbia River Gorge National Scenic Area . . . . . . . . . . . . . . . 30

II Description of the Resource Management Entities in the Columbia River Gorge National Scenic Area ........... 50

III Summary of the Cultural Resource Protection Provisions and Guidelines for the General Management Areas of the Columbia River Gorge National Scenic Area . . . . . . . . . . . . . 65

IV Descriptive, Locational, Access, and Awareness Variables of the 15 Rock Art Sites Selected for Study in the Columbia River Gorge National Scenic Area . . . . . . . . . . . . . . 77

V Statistically Significant Associations Between the Variables to the Vandalism of the 15 Rock Art Sites Selected for Study in the Columbia River Gorge National Scenic Area . . . . . . . 8 85

VI The Six Vandalized Rock Art Sites from the 15 Selected for Study and the Statistically Significant Variables Affecting Vandalism ..................... 86

VII Summary of Cultural Resource Management Recommendations for the Management Entities in the Columbia River Gorge National Scenic Area ..........................111 


\section{LIST OF FIGURES}

FIGURE

PAGE

1. The Columbia River Gorge National Scenic Area ......... 20

2. Representative Early, Middle, and Late Archaic sites in the Columbia River Gorge National Scenic Area . . . . . . . . . . 32

3. Tsagiglalal, or "She Who Watches", a petroglyph in the Columbia River Gorge National Scenic Area . . . . . . . . . . . . 39

4. Natural and cultural features in the eastern portion of the Columbia River Gorge National Scenic Area . . . . . . . . 40

5. Looter's pits, dug at the base of a rock art site in the Columbia River Gorge National Scenic Area . . . . . . . . . . 59

6. A red and white pictograph at Horsethief Lake State Park, Washington, A) before vandalization, and B) after vandalization $\ldots \ldots \ldots \ldots \ldots \ldots \ldots \ldots \ldots \ldots \ldots \ldots$

7. An example of vandalism which occurred in Horsethief Lake State Park, Washington, in the summer of $1992 \ldots . . .662$

8. The 156 prehistoric archaeological sites in the Columbia River Gorge National Scenic Area, by county . . . . . . . . . . . 64

9. The 44 non-inundated rock art sites in the Columbia River Gorge National Scenic Area .............. 71

10. Horsethief Lake State Park, Washington ............ 72

11. The 15 rock art sites selected for the study of vandalism to the rock art sites of the Columbia River Gorge National Scenic Area . . . . . . . . . . . . . . . 75

12. Off-road vehicles near a rock art site outside Wishram, Washington ................... 90 
13. Graffiti situated near a rock art site in the Columbia River Gorge National Scenic Area . . . . . . . . . . 91

14. Graffiti in the form of a recent, non-Indian petroglyph, situated near a prehistoric rock art site in the Columbia River Gorge National Scenic Area . . . . . . . 92

15. Graffiti at Horsethief Lake State Park, Washington ........ . 94

16. Rock-climber at a pictograph site in Horsethief Lake State Park, Washington .................. 96

17. Vandalized pictographs outside of Wishram, Washington ..... 97

18. Petroglyph panels salvaged during the construction of The Dalles Dam . . . . . . . . . . . . . . . . . . . 101

19. Sign at Horsethief Lake State Park, Washington, which cautions against the removal or disturbance of artifacts . . . . . . . . . . . . . . . . . . . . 104

20. The effects of pigeons on the petroglyph panels at The Dalles Dam in the Columbia River Gorge National Scenic Area . . . . . . . . . . . . . . . . . . . . . . . . . 109 


\section{CHAPTER I}

\section{INTRODUCTION}

Archaeological sites in the New World, including rock art, are the rare and endangered elements of the past cultural landscape, one that extends from the end of the Pleistocene to the present. The pressures of European-American settlement caused that landscape, and the people who created it, to be greatly diminished, and in a few cases obliterated, in a remarkably short period of time. Vandalism to remaining archaeological sites has become a serious threat to our knowledge of the past and to the cultural heritage of both North and South America, yet little is known about the patterns of vandalism. Which sites might be at risk, attributes that contribute to or inhibit vandalism, public knowledge of and access to archaeological sites, and how site ownership and management affect the likelihood of vandalism are all issues which need to be better understood in order to model effective resource management strategies.

This paper will examine factors which affect the vandalism to the rock art sites of the Columbia River Gorge National Scenic Area ("Scenic Area"). The relationship between the location of the sites and variables such as access to the sites, kind of vandalism, degree of damage, site ownership and management, and public awareness of the rock art sites will be explored. The nature and degree of vandalism to the rock art sites of the Scenic Area is hypothesized to be primarily the result of public 
awareness of, and access to, the sites. Access will be examined with reference to the ease with which sites may be located and visited, while awareness of the rock art will be considered in the context of tourist promotion, education; and cultural and economic issues. Rock art sites which are easily located and which have been the focus of public awareness are expected to be the most severely vandalized.

Rock art and other prehistoric and historic sites are cultural resources.

Cultural resources are

... the fragile and non-renewable remains of past human activity. These include sites, structures, artifacts, objects, ruins, works of art, architecture, and natural features that were of importance in human events, both historic and prehistoric. Each cultural resource represents a piece of the continuum of the events from the first inhabitants in the region to the people of today. The value of these resources lies in their potential for providing information about former lifeways and in their historical significance to the local or national community (Gorospe 1985, i).

The continuum referred to above extends from the arrival of the first Indians in the New World through to the present. This history spans many thousands of years, and little of it has been fully reconstructed. The preservation of archaeological sites and other cultural resources is vital to the complete understanding of the past, to the preservation of the remaining cultural traditions of the Indians of the Americas, and to preventing misconceptions about Indians and their ancestors.

The term "Indian" is itself a misconception. When Europeans arrived in the New World 500 years ago, they found that the continents of North and South America were occupied by a variety of indigenous peoples. Because these first explorers were seeking a route to the Asian continent in search of trade goods for 
the expanding markets of Europe, they did not at first realize that two very large continental land masses were impeding their passage, and assumed that they had indeed arrived in India or somewhere nearby. As a result, they referred to the native people they encountered as "Indians", a misnomer which has persisted into the present.

In fact, the native Indians of the New World are currently thought to be the descendants of people who migrated from Asia at a time when vast quantities of both surface and oceanic waters were consumed by immense continental glaciers. With so much water feeding the glaciers, sea levels dropped globally some 300 feet (Jennings 1989), exposing the more shallow continental shelves. One such exposure was the Bering Land Bridge, which extended from Siberia to Alaska, and it was across this land mass that the first "Indians" arrived. Exactly when this occurred remains the subject of debate, but the first migration probably took place no earlier than approximately 35,000 years B.P. (before the present), and more likely much later, around 15,000 B.P. (Butzer 1990).

In the ensuing millennia, the migrants expanded throughout North and South America, adapting to local environments, and exploiting local resources. As their numbers grew and their cultures evolved, they in turn began to impact the environment and develop unique cultural landscapes:

They created farming towns, following an independent trajectory of agricultural origins during what in Europe were the so-called Dark Ages. The farming frontier in most areas was pushed to its ecological limits, while on the west coast, alternative ways of life were developed that could support surprisingly large populations by fishing and intensified plant collecting. In the period when Gothic cathedrals were 
erected in medieval Europe, many thousands of native Americans built impressive towns in the Southwest and Mississippi Basin, sites now visited by tourists from both continents. ... It is upon this imprint that the more familiar Euro-American landscape was grafted, rather than created anew (Butzer 1990, 27-28).

The cultural florescence of New World Indians also created complex trade networks, some of which continued into the early historic period of the 1700 s. One of these trade centers was located near The Dalles, Oregon, and involved traders from throughout the Pacific Northwest, California, Canada, and the northern Great Plains (Aikens 1986; Jennings 1989).

Populations flourished along with trade. Estimates of the pre-Columbian population of North and South America vary widely among geographers and anthropologists. Earlier this century it was thought that the Americas were largely unpopulated, with no more than eight to fifteen million Indians inhabiting the New World prior to European contact. More recent estimates list figures of 43 to 65 million, indicating that the Americas were well populated when the first Europeans arrived (Denevan 1992).

But with the arrival of Europeans came exotic diseases, which decimated the Indians of both continents. Lovell $(1992,426)$ considers this "the greatest destruction of lives in history. ... European intrusion unleashed on Native American peoples abrupt and unprecedented collapse by exposing their immune systems to hitherto unknown forms of sickness." Populations fell dramatically in all regions, ranging from a $99 \%$ drop in Hispaniola just 50 years after Columbus arrived on its shores, to $74 \%$ in all of North America between 1492 and 1800 (Denevan 1992). 
Over the succeeding centuries, the European newcomers pressed inland, displacing the remaining natives from their homelands. From the Bering Sea to Tierra del Fuego, the natives lost their lands and their cultures, and many of the cultural landscapes they created were lost as well.

What is left of the long occupation of the New World by Native Americans exists today both in the oral and written histories of individuals and tribes, and in the physical evidence found in archaeological sites scattered across the modern landscape. Some of the most visible and accessible of these sites are rock art sites, which include pictographs (designs painted or drawn on stone) and petroglyphs (designs carved or etched into stone). Archaeological sites, including rock art, have suffered attrition over time, due in part to natural forces such as wind and water erosion, but due in larger part to human impacts. The Dalles Dam, for example, inundated over 400 petroglyphs in one of the largest concentrations of rock art in the Pacific Northwest, near what is now Horsethief Lake State Park in Washington. However, the sites which survive developments such as dams often fall victim to vandalism. The magnitude of the combined impact of development and vandalism is immense, and it is possible that by the year 2050, 98 percent of all archaeological remains in North America will have been destroyed (Knudson 1989).

Vandalism is defined by Webster's Ninth New Collegiate Dictionary as "willful or malignant destruction or defacement of public or private property" $(1989,1303)$. When applied to archaeological sites containing portable artifacts such as pottery, stone tools, or even burials, vandalism most often means the deliberate looting of 
such sites in order to procure artifacts for sale on a national and international black market. Davis et al. (1992) state that

Given the severity of archaeological theft today in Oregon and the Pacific Northwest, the popular term "vandalism"...does not adequately describe the kinds of resource crimes that are being committed. We suggest that, to much of the public, vandalism applied to archaeological sites simply means weekend surface artifact collecting or tracing over a rock painting with chalk. They see it as analogous to painting graffiti or carving on a public building, or worse, destroying the facilities inside. This kind of destructive behavior is a nuisance and expensive, but the damage is often reversible.

In reality, cultural resource "vandalism" is much more serious. Fragile cultural sites are being systematically destroyed every day by artifact thieves. This activity is irreversible, and the resource loss is immense. Archaeological site destruction is not only a crime against property, it is a crime against people; for it is the graves, campsites and sacred places of American Indian peoples that are being despoiled (203-204).

While vandalism of rock art sites can sometimes involve removing individual petroglyphs or pictographs for black market trade, it more often involves either inadvertent or deliberate damage. Inadvertent vandalism lacks the intent to destroy that is present in deliberate vandalism, and occurs in instances where rock art is outlined with chalk or other materials to make it more visible for photographs, or when paints are used to make rubbings from petroglyphs and residue is left behind. Deliberate vandalism appears to be the result of an intent to damage or obliterate the rock art. Examples of deliberate vandalism include graffiti applied over a rock art image, rock art damaged by attempts to remove it, and gunshot damage.

The relationship between access, awareness, and vandalism has not been well studied. However, the position of rock art sites in the landscape relative to locational attributes such as site ownership and management, proximity to roads, paths, and 
other forms of access, and public awareness of the existence and location of the rock art sites, suggests that vandalism to the rock art of the Scenic Area is tied to public awareness of, and access to, the rock art sites. Access involves the ease of locating and visiting these sites, while awareness, both of the existence and location of the rock art, is created by education, tourism promotion, and cultural and economic issues. Thus, rock art sites within the Scenic Area which are easily located and which have been the focus of public awareness are expected to be the most severely vandalized. 


\section{CHAPTER II}

\section{LITERATURE REVIEW}

Literature on vandalism appears in a wide variety of printed formats, from newspapers to professional books and journals. Whether popular or professional in nature, this body of literature focuses almost exclusively on vandalism which occurs in urban settings. The vandalization of mass transit systems, city parks, schools, and other public facilities is well represented in the literature (Gottfredson 1985; National Conference on Mass Transit Crime and Vandalism 1981; Winter 1992). Other publications examine vandalism perpetrated by animal-rights groups on laboratories which engage in experiments involving animals, and the application of graffiti over both public and private properties in urban settings (Bell et al. 1992; Blumenstyk 1992; Brewer et al. 1992; Sun 1990; and Van D’Elden 1992).

Although both urban and rural vandalism have been perpetrated by both men and women, young and old, most urban vandalism is carried out by young males against the built environment (Van Vliet 1992). This type of vandalism has been described as "a type of 'nihilistic violence', directed at material things representing a superior order or an authority of a developed culture. . . The perpetrator sees meaning in marking symbols of [his] power over the physical environment" (Roos 1992, 74-75). Brewer et al. (1992) also view some types of urban graffiti as expressions of power and rebellion by a subculture whose values conflict with the 
values of the dominant culture.

In contrast to the volume of work available on urban vandalism, the vandalism to archaeological resources is less well studied and the literature less abundant. What reports exist appear in popular formats such as newspapers and magazines, including National Geographic (Arden 1989), Science, Archaeology (Knudson 1989), American Forests (Harris 1991), and National Parks (Wilkinson 1991).

The motives for vandalizing most archaeological sites are well known, and are cited in virtually every publication regarding cultural resource vandalism. Two kinds of vandalism are recognized: recreational collecting and for-profit looting (Davis et al. 1992; Society for American Archaeology 1990). Recreational collecting is considered to be less damaging than profit-oriented looting, and usually consists of families or individuals who remove artifacts from the ground surface for their home collections. Many who engage in this activity began doing so on their own or their neighbor's privately-owned land, and extended their activities to public lands when the opportunity arose (for example, during camping trips or hunting or fishing expeditions). Such activities are usually regarded as examples of inadvertent vandalism, because there is no intent to damage or destroy the site, and it is often assumed that most collectors are unaware of the damage that their activities cause.

Profit-oriented looting, on the other hand, is considered to be an act of deliberate vandalism. This kind of looting is carried out in order to acquire artifacts for sale (Davis et al. 1992; Landers 1991; Meyer 1973). It usually involves subsurface excavation to locate and retrieve artifacts, often with the use of heavy 
machinery such as backhoes and bulldozers, and occurs on public and private lands.

Although a profit motive for such activities has always been a hallmark of archaeological vandalism, some writers (Landers 1991; Meyer 1973) cite an auction of Native American items by Parke-Bernet in 1971 as an event which sharply increased the demand for artifacts:

Before the sale, Parke-Bernet had estimated that the 310 items in the collection would fetch between $\$ 40,000$ and $\$ 67,000$. As it turned out, however, the proceeds came to more than $\$ 161,000$.

A Navajo blanket that had sold at Parke-Bernet for $\$ 100$ in 1963 brought $\$ 1,000$. A tomahawk nearly three feet long brought $\$ 1,400$. An Indian ceremonial hide shirt went for $\$ 4,500$. . . In the years since, strong interest in Indian artifacts has been manifested not only in the United States but in Japan, Germany and elsewhere. . . . The result of all this increased demand for Indian artifacts has been the increased mining of archaeological sites for profit (Landers 1991, 36-37).

Davis et al. (1992) cite the theft from USDA Forest Service land in Oregon of 500 obsidian projectile points, 250 of which were sold for $\$ 6,500$ to a government agent in a sting operation which ultimately resulted in the first felony conviction in Oregon under the Archaeological Resource Protection Act ("ARPA").

Professional literature which describes or analyzes vandalism to cultural resources is rare. Several comments describing the threat to cultural resources from vandals appeared in the early 1970 s in American Antiquity, the journal of the Society for American Archaeologists: Clewlow et al. (1971) document looting of archaeological sites in the Great Basin region of the American Southwest, and call for increased public education and involvement to aid in preventing further destruction; McGimsey (1971) also urges public involvement; and Beals (1971) 
proposes several steps towards curbing the illicit international trade in antiquities, including the use of heavy tariffs on the import of antiquities, an excise tax on the sale of antiquities in the United States, and closer monitoring of antiquities acquisitions by museums world-wide. Since that time, only a few papers have been published on this topic, and these deal largely with related issues, such as treatment of Indian burials and grave goods, and the legal and professional ramifications of laws such as ARPA. The Journal of Field Archaeology, published by the Association for Field Archaeology, includes a section titled "The Antiquities Market" in almost every issue. "The Antiquities Market" deals primarily with the international theft of artifacts and antiquities from archaeological sites, private collections, and museums. A separate section in this journal, "Preservation and Rescue", examines cultural resource management issues in the United States and abroad, and includes updates on national and international preservation laws. Although this kind of information is helpful in providing a broader understanding of the motivations for archaeological site vandalism world-wide, it does not provide in-depth analyses of the specific nature of site vandalism, nor does it identify high-risk sites relative to access and awareness.

Closer to home, Current Archaeological Happenings in Oregon (CAHO) frequently refers to the looting and vandalism of archaeological sites in Oregon. This newsletter, published by the Association of Oregon Archaeologists, contains reports written predominantly by archaeologists working for government agencies such as the USDA Forest Service and the Bureau of Land Management. These accounts are confined to the looting and vandalism that take place on public lands administered 
by these agencies, and while containing valuable descriptive material, are largely anecdotal in nature.

The same is true for the larger government publications issued by agencies such as the Bureau of Land Management, the USDA Forest Service, and the General Accounting Office (General Accounting Office, 1987; Lyneis et al. 1980; Williams 1978). Most of this literature is written by agency archaeologists, and their research usually consists of descriptive inventories and anecdotal histories of the effects of vandalism on all types of archaeological sites within the public lands managed by the agency. Most references are to the Southwest region of the United States, due to the relatively high density of archaeological sites in this area and to the relatively large volume of land which is owned and managed by the federal government.

The focus of many reports (Blackburn 1992; Higgins 1992; Pilles 1989) is on management techniques to prevent and ameliorate the effects of vandalism to cultural resources. Pilles (1989) suggests multiple approaches, including increased law enforcement, removal of graffiti from rock art sites, use of professional tour companies to escort and monitor visitors within archaeological sites, and the participation of local school children in recording and mapping archaeological sites. Higgins (1992) proposes three management techniques for preserving rock art: repairing the damage to the site, including the removal of graffiti; protection of the sites, which can include erecting physical barriers to prevent access, in addition to increased law enforcement; and public education of the value of the resource, including guided public viewing of the vandalized sites, and media presentations and 
exhibits. Education is further emphasized by Blackburn (1992), who recommends community involvement with professional archaeologists, encouraging volunteers to work on archaeological surveys and excavations.

Three separate studies by Williams (1978), Nickens et al. (1981), and Downer (1992) have attempted to analyze some of the relationships between site location, ease of access, and vandalism. These authors expanded the scope of their descriptive inventories to include a limited locational analysis of sites which were found to be vandalized on public lands in the Southwest.

In his 1978 study for the USDA Forest Service, Vandalism to Cultural Resources of the Rocky Mountain West, Williams' main objective was to collect information which would "identify the characteristics of cultural resource vandalism in dispersed recreation areas, and to compare these characteristics with those for non-cultural resource vandalism" (Williams 1978,4 ). Williams used a questionnaire to survey resource managers in nine states, including archaeologists, representing the Bureau of Land Management, the USDA Forest Service, the Bureau of Reclamation, the National Park Service, and the Colorado Division of Parks and Outdoor Recreation. The questionnaire was designed to elicit overall impressions from land managers concerning trends in vandalism, rather than to obtain specific data about specific sites. None of the respondents were required to visit sites or to review archival materials which could document site vandalism. Williams found that access to and awareness of cultural resource sites were tied to site vandalism: increased tourism and visitation to recreation areas, use of 4-wheel drive vehicles to gain access, 
and the knowledge and awareness of sites by people living in the vicinity (who frequently surface collect from sites, and possibly pothunt ${ }^{1}$ as well) combine to increase the likelihood of site vandalism. Further, his survey indicates that while most of the vandalism to archaeological sites in general takes the form of looting or surface collecting, vandalism to rock art sites tended to be "wantonly destructive" (129). Rock art commonly was found to be damaged by removal of images, painting and chalking over the images, and gunshot damage inflicted by people using the rock art for target practice. Visibility, evidence of previous vandalism, and location in an area of frequent visitor use were attributes thought to encourage rock art vandalism, according to respondents to the questionnaire.

In A Survey of Vandalism to Archaeological Resources in Southwestern Colorado, Nickens et al. (1981) examined several factors thought to affect vandalism of archaeological sites within the study area, the Bureau of Land Management's Sacred Mountain Planning Unit. These include "1) the density, distribution, and visibility of archaeological resources in the project area; and 2) the relative ease by which access may be gained to sites where digging and/or surface collection may be undertaken" (129). Site type, attitudes and values towards pothunting, legal actions undertaken to curb pothunting, the effect of the burgeoning antiquities market, and the long history of site vandalism in the area were also considered. Using two separate site samples from the project area, Nickens et al. determined that site type and access

\footnotetext{
1 "Pothunt" and "pothunting" are terms used by archaeologists and cultural resource managers to describe the illegal acquisition of artifacts, not just pots, whether from surface collecting or from excavation.
} 
were both significant factors in site vandalism: $41 \%$ of masonry sites such as pueblos, cliff dwellings, and kivas were found to be vandalized, compared with $21 \%$ of nonmasonry sites. Forty-seven percent of rock art sites were vandalized, all by graffiti. Access was evaluated in terms of 1 ) distance from the site to the nearest road; 2 ) type of nearest road (paved, gravel, dirt, etc.); and 3) distance to nearest town. Although sites situated near roads of almost every type proved to be more frequently vandalized, the overall findings regarding access indicate that masonry sites "located over 20 miles from the nearest town and within 100 meters of a dirt road would appear to be the most vulnerable to vandalism " (59).

In addition, Nickens et al. interviewed 20 non-random "informants" who were known to engage in artifact collection activities on public and private lands. The interview questionnaire encompassed topics such as frequency of collection activities, knowledge of local archaeology and history, perception of archaeologists, and attitudes towards government and public lands. Also included were questions concerning the ease of access and knowledge of site locations. Data obtained by the questionnaire indicate that most of the informants were local people familiar with site locations, who did not drive long distances to get to sites. Nickens et al. concluded that the primary factors which affected the vandalism of archaeological sites in the study area were 1) the ease with which the sites could be accessed, and 2) the type, age, distribution, and visibility of the sites. The authors also cited several subsidiary factors, including the market for illegally obtained artifacts, the long history of pothunting in the region, and the attitudes of local artifact collectors towards cultural 
resources.

Downer's 1992 article, more limited in scope than either Williams or Nickens et al., explored the relationship between access and isolation to the vandalism of ten archaeological sites on the Navajo Reservation in the Four Corners area of the southwestern United States. The sites consisted of structures such as pueblos and cliff dwellings, and were rated on a scale of 1 to 5 in terms of accessibility and isolation. Downer found that sites which were easily to moderately difficult to access, and which were moderately to extremely isolated, tended to experience more vandalism than did sites which were difficult to access (no matter how isolated). The roads used to access the vandalized sites were also isolated. Downer suggested that isolation of both the site and the means of access is required by looters in order to escape detection and possible prosecution for their activities.

Vandalism of rock art sites has been discussed by a limited number of authors. Descriptive articles which provide a sense of the magnitude of the damage to certain sites are common in popular and amateur publications, especially those in Australia, a country with an abundance of aboriginal rock art. Other publications deal specifically with methods of restoring damaged rock art, or offer management suggestions for the prevention of further damage (Cartwright 1989; Gale and Jacobs 1987; Rosenfeld 1988; Sullivan n.d.).

Gale (1985) specifically dealt with the inadvertent aspects of visitor damage to rock art at three rock art sites in two national parks in Australia in 1982. The aim of this project was to observe and assess the behavior of visitors at the rock art sites 
in order to determine which sites were the most likely to experience destructive tourist behavior, and to aid in the development of future management plans to protect the rock art. Visitor pressure has increased dramatically in these parks due to the development of roads, motels, and the tourist industry in general. Gale stated that while deliberate acts of vandalism are relatively rare, inadvertent damage, mostly the result of visitors touching the rock art, is quite common. Although overall access to and awareness of the rock art was depicted as having increased dramatically in a relatively short time, Gale examined access in the context of individual rock art sites situated within a larger complex containing several such sites, and found that rock art sites which were more difficult to access within a complex received one third to one quarter less visitors than those reached more easily, and thus experienced less damage from touching. Gale also discovered that simple signs, reading "Please Do Not Touch The Rock Art" were "spectacular" in their effects: visitors did indeed make a concerted effort not to touch the rock art after such signs were installed. From these observations, Gale determined that parks containing aboriginal rock art should plan carefully to control visitor access so that large numbers of people can view the rock art without inadvertently damaging it.

Although sparse and often lacking research goals or analysis, the available literature concerning vandalism to archaeological sites in general, and rock art sites in particular, contributes a general understanding of the extent and degree of the damage inflicted by both casual collectors and profit-oriented looters. The motivations of archaeological vandals are understood both as the result of personal 
curiosity and as a recreational habit, and as the consequence of the potentially high profits derived from the sale of artifacts and antiquities world-wide. Less well understood is the correlation between access, awareness, and vandalism to rock art sites. These sites are more often damaged inadvertently by incautious visitors, or deliberately by graffiti and other forms of defacement, rather than by profit-oriented looters.

The rock art sites of the Columbia River Gorge National Scenic Area provide a unique opportunity to examine rock art vandalism and to suggest management alternatives to such vandalism. The Columbia River Gorge is a unique and dynamic region, and its natural and cultural histories extend many thousands of years. Because the natural and cultural resources of the Scenic Area have suffered attrition over time, largely from human intervention, the Columbia River Gorge National Scenic Area Act was passed in 1986 to provide comprehensive resource management of the area.

Research which would illuminate the relationship between location, access, public awareness, and the vandalism of rock art and other archaeological sites has been called for by cultural resource managers, particularly those in the Southwest. McAllister (1988) states that "... we can expect that efforts to substantially reduce the looting and vandalism of archaeological resources will be of limited effectiveness until further research is accomplished. The problem will not be solved until it is more completely understood" (61). 


\section{CHAPTER III}

\section{LOCATION AND DESCRIPTION OF THE STUDY AREA}

The Columbia River Gorge National Scenic Area consists of approximately 1,184.3 square kilometers along the Columbia River in Washington and Oregon, bounded by the Sandy River on the west and the Deschutes River on the east (Fig. 1). The Scenic Area (also referred to as "the Gorge") includes the gorge of the Columbia River, and encompasses parts of Clark, Skamania, and Klickitat counties in Washington, and portions of Multnomah, Hood River, and Wasco counties in Oregon. The Scenic Area has been the nexus of subsistence, habitation, transportation, recreation, and economic activity since humans first inhabited the region over 10,000 years ago. As a nearly sea-level passage through the Cascade mountain range, the Columbia River Gorge within the Scenic Area has functioned as a conduit for transportation, facilitating settlement and economic exploitation. The process began before European contact, with the movement of native peoples between coastal and inland regions. Later, the Gorge served as one of the last and most perilous segments of the Oregon Trail, as thousands of hopeful settlers entrusted their lives and their possessions to the rafts, canoes, and ferries that traversed the dangerous rapids of the Columbia as it breached the Cascade Range. Today, those rapids and others are submerged under the waters of the Bonneville and The Dalles dams, while barges carrying 


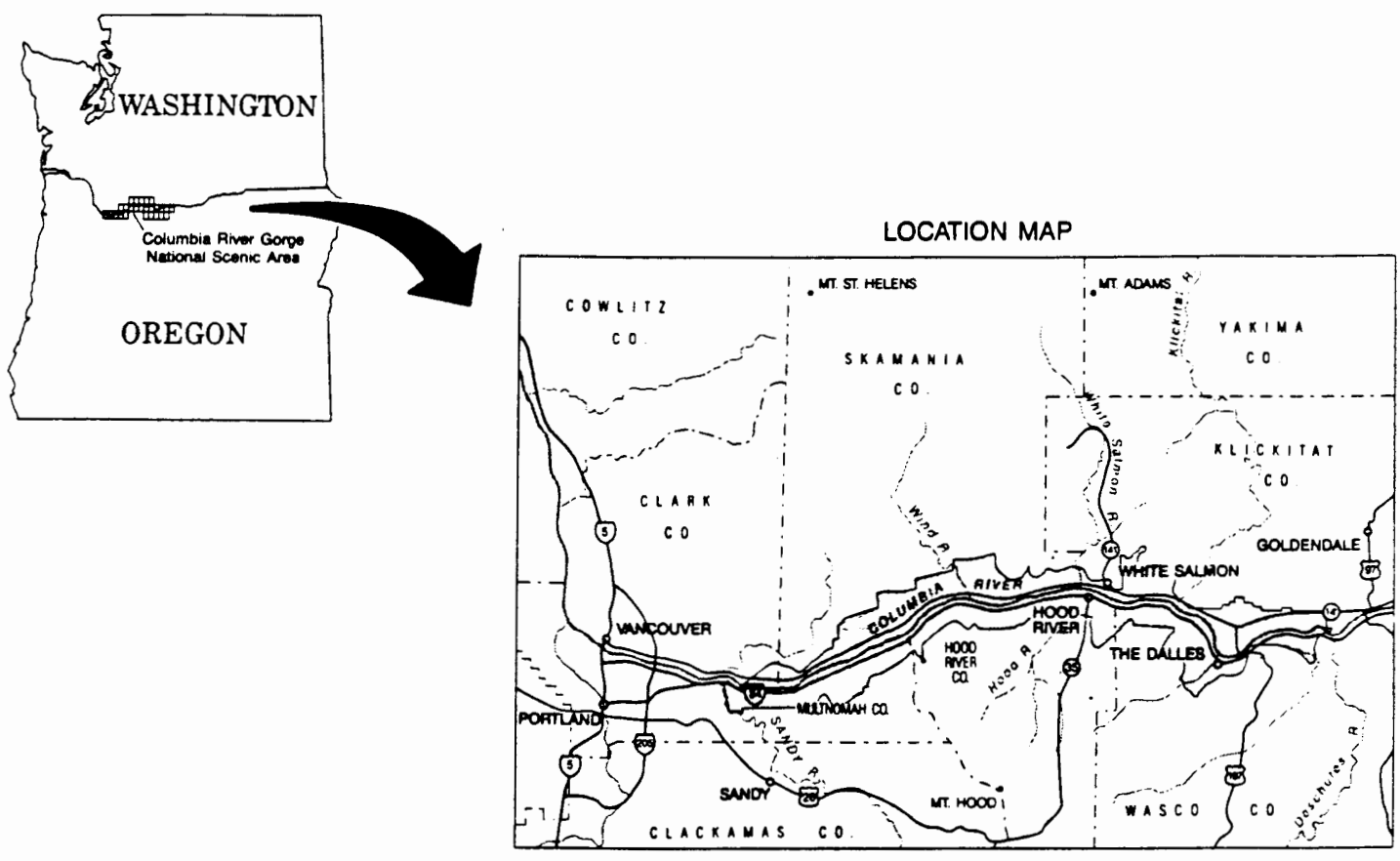

MANAGEMENT AREAS

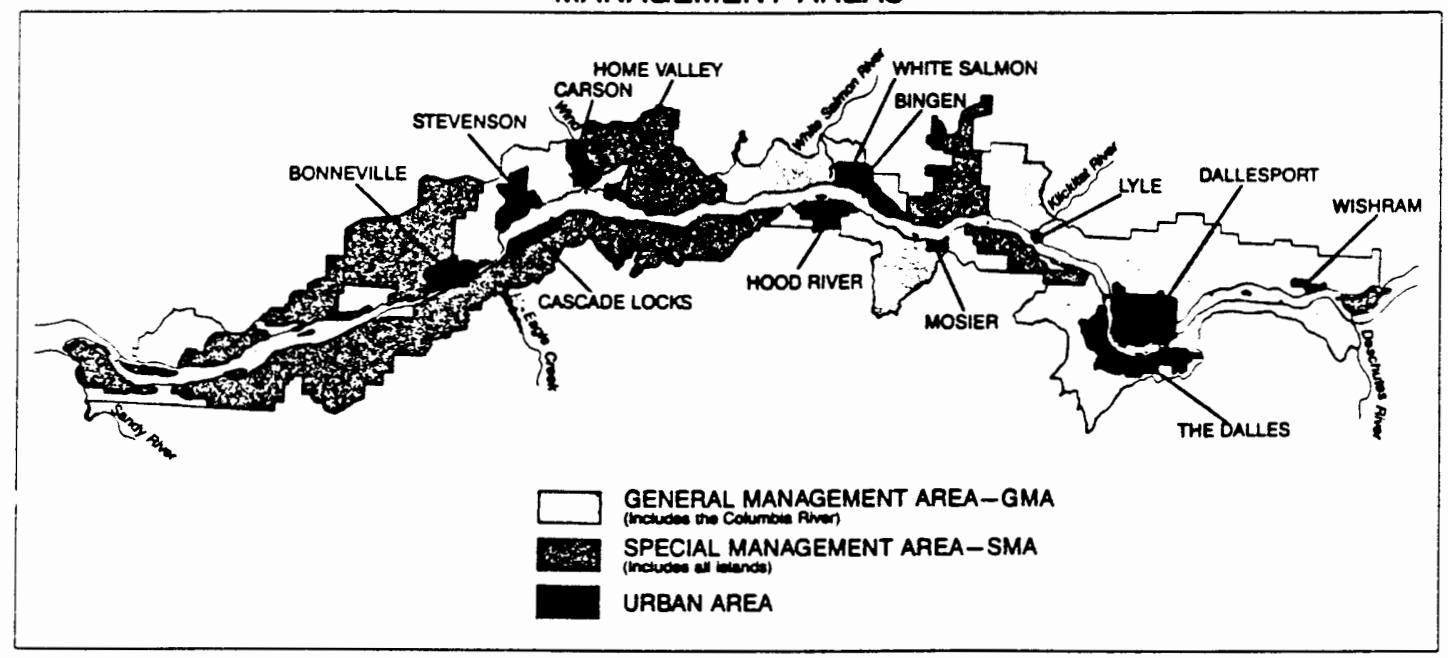

Figure 1. The Columbia River Gorge National Scenic Area. From the Management Plan for the Columbia River Gorge National Scenic Area (1992). 
agricultural and forest products sail the now-placid waters. Railroads transport goods and people on both shores of the Columbia through the Gorge, while U.S. Highway 14 on the Washington side and Interstate 84 on the Oregon side are used to transport people and commodities.

From its volcanic inception during the Miocene epoch and continuing to the present, the landscape of the Gorge within the Scenic Area has changed dramatically, first by powerful natural forces and more recently by human interventions almost equally powerful in their effects. The location of aboriginal rock art sites is explained in part by the geologic formation of the Gorge.

\section{GEOLOGY AND PHYSIOGRAPHY OF THE GORGE}

The geologic foundations of the Gorge are primarily the result of numerous episodes of volcanic activity, beginning some 58 million years ago and continuing sporadically up to the present. Most of this activity occurred in the late Miocene, when massive basalt flows covered much of eastern Washington and Oregon. The lava from these flows originated in central and eastern Washington and Oregon, and flowed westward down the Columbia River valley to the sea (Allen 1984). These flows, known today as the Yakima Basalt of the Columbia River Basalt Group, formed the major cliffs of the Gorge (Reese 1988).

Following the deposition of the Yakima Basalt, the Cascades were uparched between the Willamette Valley and the Hood River Valley. As the mountains were rising, the Columbia River was down-cutting through the range, 
creating a deep, V-shaped valley. Later, during the Plio-Pleistocene, volcanic activity resumed in the Cascades, producing lava flows which filled the tributaries of the Columbia and which displaced the river to the north, near its present position. The strato volcano peaks of Mt. Hood, Mt. St. Helens, and Mt. Adams also began to rise some 700,000 years ago, a process which continues into the present (Reese 1988). The up-arching of the Cascades and the creation of the strato volcanoes formed the climatic division of the region into the moist western and dry eastern portions (Allen 1984). In the Gorge, this climate change occurs around Hood River, coinciding with the abrupt transition from the more steepsided, mesic, and densely vegetated river gorge which cuts through the Cascades, to the dryer and more rolling grassy hills which surround the river to the east. Although a great deal of volcanic activity took place prior to the Pleistocene, it was the geological events of the Pleistocene itself which shaped the Gorge into its present configurations. The most important of these events were the Bretz (or Missoula) floods. As many as 40 of these floods (Allen 1984) occurred from 15,000 to 12,800 B.P., when ice dams created by a lobe of the Cordilleran ice sheet impounded the waters of glacial Lake Missoula in northwest Montana. Pressure from the impounded waters would periodically cause the dam to fail, sending an estimated 208,500 cubic kilometers of water down the channel of the Columbia River and through the Gorge, an amount roughly equivalent to half the volume of Lake Michigan. The flood waters rushed across eastern Washington and Oregon and through the Gorge at approximately 39.6 cubic 
kilometers per hour, for at least 40 hours during each flood event (Allen 1984). The enormous force and volume of the floods scoured away the soils of the Gorge and altered the river valley from its previous V-shape to its present U-shape. In so doing, the floods also sheared away parts of the ridges on the south side of the Columbia River Gorge, "creating triangular slopes between the tributary valleys. . . and left the streams hanging high on the walls to form the waterfalls and cliffs which now contribute so much to its scenic grandeur" (Allen et al. 1986, 159).

Landslides followed the Bretz floods. These were the result not only of the over-steepening of the Gorge walls during the floods, but also of the inclination of the land and of the stratigraphy of the bedrock. The Yakima Basalt of the Gorge caps the older Eagle Creek formation, made up largely of Miocene ash and mudflows, which can become saturated when water percolates through the porous Yakima Basalt. As it becomes saturated, the Eagle Creek stratum becomes increasingly unstable and slippery. The few degrees' tilt of the land toward the southeast and the undercutting of the north shore by the Columbia increase the instability of the area in the vicinity of the Cascade Locks. Both excessive rainfall and earthquakes have initiated landslides under these conditions, the largest of which took place in an area just north of Bonneville beginning in the late Pleistocene. Here a series of four landslides, known as the Cascade Landslides, covered a total of approximately 35.9 square kilometers on the Washington side of the river. The most recent of these, the Bonneville Landslide, has been dated to around 730 B.P., and covers some 14.1 square kilometers. Debris from this slide 
fell across the Columbia and pushed up the Oregon shore, completely blocking the river and displacing the channel a mile to the south.

The blockage resulted in the ponding of the Columbia to a depth of 60.6 to 91 meters, until it was overtopped and eroded. One of the results of the erosion of the landslide debris was the creation of the "Cascades of the Columbia", a series of steep rapids which were not readily navigable, forcing travelers to portage around them. Although these rapids are now submerged behind the Bonneville Dam, other remnants of the Bonneville Landslide are still visible today, including Hamilton, Ives, and Pierce islands.

The landscape of the Scenic Area east of Hood River and the Cascade mountains is more open, with a wider river canyon ranging from three to eight kilometers across. The hills which rise above each side of the river here are uneven in height, with those on the Washington side much higher than those on the Oregon side. This is due to the effects of the Columbia River anticline, which has raised the old basalt flows on the north to elevations as high as 900 meters. The Oregon side, as part of the northern-dipping Deschutes-Umatilla Plateau, seldom achieves elevations above 300 meters (Baldwin 1981; Wilke et al. 1983). In this eastern portion of the Scenic Area, the Columbia River Basalts are overlain in places by The Dalles formation, a layer of conglomerate and tuffaceous sedimentary rock deposited in the Miocene and Pliocene (Baldwin 1981). Because The Dalles formation is more easily eroded than the underlying basalts, its topography is associated with the gently rolling and sloping landforms of the 
eastern Scenic Area. Where it is not covered by The Dalles formation, the Columbia River Basalt, by contrast, provides increased vertical relief, with exposed walls of dark gray, fine-grained columnar cliffs and walls. The columnar walls, particularly those which face the Columbia River, were frequently utilized in the creation of aboriginal rock art.

A geological feature which contributed to the prehistoric settlement and subsistence in the Scenic Area was a small upwarp in the basin of the Columbia. This created a series of falls and rapids which early French-Canadian fur traders called "The Dalles" (literally meaning "flagstones", referring to the large flat basalt intrusions in the channel of the Columbia). The Dalles of the Columbia included Celilo Falls and Fivemile Rapids, while the entire area was sometimes referred to as The Long Narrows or the Great Falls of the Columbia. The whole feature was approximately 19.4 kilometers long, beginning a few kilometers upstream from the present-day city of The Dalles, and had an 24.5 meter drop at low water (Hitchman 1985). Before being inundated by The Dalles Dam in 1957, The Dalles was the site of the most popular aboriginal fisheries on the Columbia, sustaining a large population. During the period of Euro-American expansion into the region, the falls and rapids were also serious navigation hazards which forced river travelers to shore for a lengthy portage, a portage which the Indians of the area had also experienced. 


\section{CLIMATE AND VEGETATION OF THE SCENIC AREA}

The Columbia River Gorge National Scenic Area encompasses two diverse types of climate: a marine climate west of the Cascades and a continental climate east of the mountains.

A marine climate is the result of the proximity to and influence of the sea. Its atmosphere is distinguished by a high moisture content, with small diurnal and annual temperature ranges. Continental climates are typical of large inland areas, with a drier air mass, irregular precipitation, and large diurnal and annual temperature ranges. The Cascade mountains are the division between these two climate types in the Gorge. Marine air brought east by the prevailing westerly winds rises over the mountains, where it expands, cools, and loses most of its moisture in the form of precipitation. When this air mass reaches the eastern slopes, it compresses and warms as it descends, yielding little precipitation. The effect of the Cascades on the climate of the Scenic Area is revealed in the annual rainfall totals from west to east: 192 centimeters at Cascades Locks; 76 centimeters at Hood River; and 35 centimeters at The Dalles (Lynott 1966).

The abrupt transition from a marine to a continental climate also determines the location of vegetation communities. Mesic conifer forests are present in the western Gorge, composed primarily of western hemlock (Tsuga heterophylla), western red cedar (Thuja plicata), and Douglas fir (Pseudotsuga menziesii). The understory consists of vine maple (Acer circinatum), red huckleberry (Vaccinium parvifolium), salal (Gaultheria shallon), and Oregon grape 
(Berberis aquifolium) (Detling 1966; Reese 1986). East of the Cascades, ponderosa pine forests and grasslands predominate. Grassland vegetation, which is most prevalent between the mouth of the Deschutes River and The Dalles, includes species such as big sagebrush (Artemisia tridentata), bluebunch wheatgrass (Agropyron spicatum), needle grasses (Stipa comata and S. thurberiana), and cheatgrass (Bromus tectorum). Most of these are characteristic of the prairie vegetation found on the Columbia Plateau, and some, such as sagebrush, have greatly expanded their range and density due to the impacts of grazing and agriculture. The grasslands gradually give way to ponderosa pine stands (Pinus ponderosa) between The Dalles and the eastern slopes of the Cascades. Other tree species in this community include grand fir (Tsuga heterophylla), western larch (Larix Occidentalis), western white pine (Pinus monticola), and incense-cedar (Librocedrus decurrlins) (Reese 1986).

\section{FAUNA}

One of the most frequently cited sources of information concerning wildlife in the Columbia River Gorge is Vernon Bailey's 1936 The Mammals and Lifezones of Oregon, published by the U.S. Department of Agriculture. He included mule deer (Odocoileus hemionus macrotis), black-tailed deer ( $O$. virginianus), Roosevelt elk (Cervus canadensis roosevelti), mountain sheep (Ovis canadensis californiana), and mountain goat (Oreamnos americanus americanus) among the herbivores which inhabited the Gorge. Predators included cougar 
(Felis concolor oregonensis), bobcat (Lynx rufus), coyote (Canis latrans) and timber wolf (Canis lupus). Black bears (Ursus americanus) were also present, as well as smaller mammals such as squirrels, rabbits, fox, weasel, and beaver. Migratory waterfowl, including several species of ducks and geese, were also common in the Gorge. Bailey's work is now over 50 years old and it is highly probable that today at least some species listed above are either reduced in numbers or absent altogether from the Scenic Area, the result of increased human populations and development. However, no further wildlife inventories are currently available. The species which have received the most media attention and which are currently the most threatened by human activities not only in the Gorge, but in the entire Columbia-Snake river system, are the anadromous fish populations, particularly salmon. There are five salmon species native to the Columbia River: pink (Oncorhynchus gorbuscha), sockeye (O. nerka), chum (O. keta), coho (O. kisutch), and chinook (O. tschawytscha). Salmon runs once numbered approximately 14 million in the Columbia Basin during the early 1800 s, while today only around 2.5 million salmon and steelhead migrate up the Columbia River and its tributaries. The commercial catch has declined correspondingly, from about 43 million pounds in the 1880 s to 1.2 million pounds in the 1980 s (U.S. Department of the Interior, Fish and Wildlife Service 1991). The precipitous depletion of the salmon runs can be attributed to a number of causes, including overfishing and loss of habitat from overgrazing, logging, and farming. The single biggest contributing factor, however, is the numerous dams on the Columbia and its tributaries, which have eliminated 
some $56 \%$ of the spawning habitat on the Columbia (U.S. Department of the Interior, Fish and Wildlife Service 1991). The Endangered Species Act was invoked by the decline in salmon runs in 1992: the Snake River sockeye was listed as endangered, while the spring, summer, and fall runs of chinook have been listed as threatened.

\section{PREHISTORY}

No comprehensive cultural chronology has been developed for the Columbia River Gorge, or for the Pacific Northwest region as a whole. In addition, the prehistoric record of the Gorge is poor for several reasons: 1) the Bonneville Landslides obliterated the archaeological sites in the area; 2) there was biased sampling of archaeological sites due to mitigation efforts during the construction of the Bonneville and The Dalles dams; 3 ) there is an overall lack of archaeological research in the Gorge; and 4) there are effects from development, especially the inundation of numerous sites in the pools formed by the two dams. Minor (1988) offers a broad, general chronology with references to the sites located in the Scenic Area and elsewhere in the Pacific Northwest. His continuum, which is adapted below (Table I), extends from the Paleo-Indian stage, prior to 10,000 B.P., through the Early, Middle, and Late Archaic stages, which includes the beginning of European contact and expansion into the region. Figure 2 identifies some of the representative sites from the Early, Middle, and Late Archaic periods. 
CULTURAL STAGES AND ASSOCIATED SITES IN THE COLUMBIA RIVER GORGE NATIONAL SCENIC AREA

Cultural stage

Paleo-Indian

Early Archaic

Middle Archaic
Approximate duration

? - 10,000 B.P.

10,000 - 7,500 B.P.

7,500 - 3,000 B.P.

\section{Description}

Diagnostic artifacts include fluted and unfluted lanceolate projectile points.

Outside of the Pacific Northwest, these points are sometimes found in association with the remains of extinct megafauna such as mastodons.

Information concerning this period is very scarce.

Smaller dart points, used to hunt smaller animals, are typical of this stage, while a few mortars and other plant processing implements are sometimes found as well. An increased reliance on plant resources and smaller game may be indicative of environmental changes which contributed to the extinction of North American megafauna.

Stemmed triangular dart points from this period are thought to have been used with atlatls. Housepit remains found elsewhere in the Pacific

Northwest indicate the beginning of the shift from nomadism to sedentism.

Very little material has been recovered from this stage in the Scenic Area.
Sites in the Scenic Area

none

Fivemile Rapids, Bob's Point, Indian Wells I.

Fivemile Rapids, Bob's Point, Congdon, Home Valley Park. 


\section{TABLE I}

CULTURAL STAGES AND ASSOCIATED SITES IN THE COLUMBIA RIVER GORGE NATIONAL SCENIC AREA

(continued)

Cultural stage

Late Archaic
Approximate duration

3,000 - 200 B.P.

\section{Description}

Considered the most culturally and technologically complex stage. Houses and villages appear. Increasing reliance on salmon and other anadromous fish. Food preservation techniques and the abundance of fish and plant resources lead to increased population. Rock art created during this stage.
Sites in the Scenic Area

Wakemap Mound, Petroglyph Canyon, Miller Island, and several in the Cascades area. 


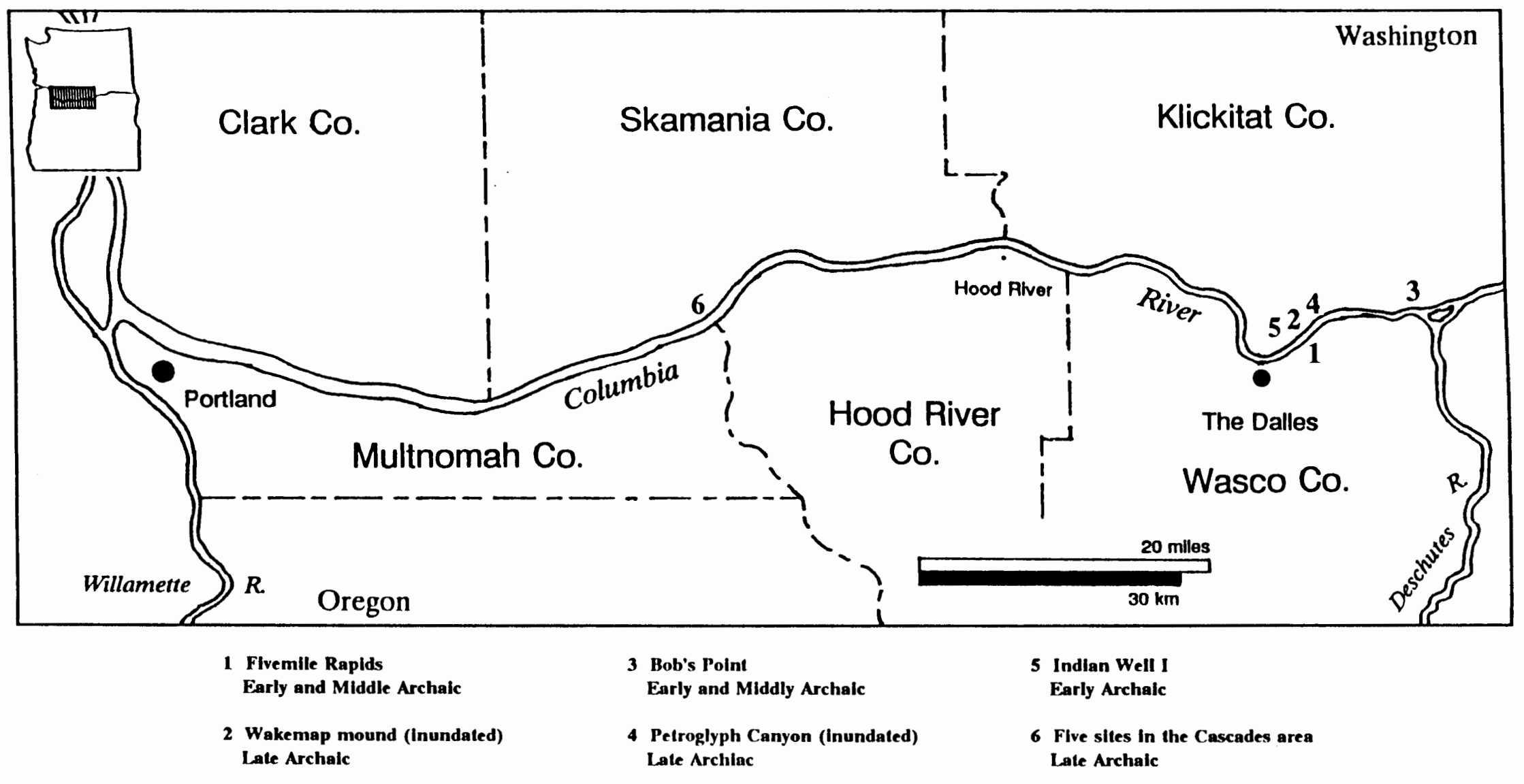

Figure 2. Representative Early, Middle, and Late Archaic sites in the Columbia River Gorge National Scenic Area. Base map from Beckham et al. (1988). 
The Paleo-Indian tradition is poorly represented throughout the Pacific Northwest, and no sites from this era are known in the Gorge. The lack of such sites in the Gorge may be due to the effects of the Bretz floods. The Paleo-Indian stage is associated with the retreat of the Pleistocene glaciers, the resultant climate change, and the hunting of big game, including now-extinct megafauna.

The Early Archaic stage, which continued from approximately 10,000 to 7,500 B.P., is characterized by adaptation to climate change. This is inferred by the presence of such artifacts as mortars and other grinding implements, suggesting the increased utilization of plant resources as a result of the extinction of large megafauna at the end of the Pleistocene. Also present in Early Archaic sites are dart points for use with atlatls, which, with the increased presence of small mammal remains, indicates a broader subsistence base than that of the preceding Paleo-Indian stage.

The most noteworthy Early Archaic site in the Scenic Area is the Fivemile Rapids site, excavated by Luther S. Cressman of the University of Oregon in 1952 and 1956. This site, located near The Dalles on the Oregon shore, contains deposits which indicate that it was discontinuously occupied from almost 10,000 B.P. to initial European contact in the late 1700s. The presence of small mammal bones and large quantities of salmon vertebrae from the oldest stratum at this site suggests that the people who first lived here were beginning a transition to the broader-based subsistence pattern associated with the Early and Middle Archaic. In addition to the Fivemile Rapids site, the Indian Well I site and the Bob's Point 
sites on the Washington shore have also been dated to the Early Archaic. Less information has been recovered from these sites, particularly at Bob's Point, which is largely inundated by the pool formed by The Dalles Dam. The remainder of the site has been severely damaged by looting.

The Middle Archaic, which lasted from roughly 7,500 to 3,000 B.P., occurred during the climatic shift known as the Altithermal, when a warmer and drier climate than that of the present became established. Both the Fivemile Rapids site and the Bob's Point sites contain components which date to this period. Although both of these sites contained fish bones from their Early Archaic strata, most of the faunal remains recovered from the Middle Archaic strata consist of large mammal bones. These sites do not appear to have been continuously occupied during the Middle Archaic. It is unknown whether the apparent subsistence focus on mammals and the intermittent occupation of the sites are related, and if these events occurred in response to the climatic effects of the Altithermal. Little information has been recovered from the Gorge corresponding to the Middle Archaic, partly due to the effects of looting on the Washington shore (Minor 1988). However, at some point during the Middle Archaic, housepits began to appear in the archaeological record of the Pacific Northwest, indicating a possible shift from what Binford (1980) has termed "residential mobility" to "logistical mobility". This means that, rather than living in temporary camps and moving all the inhabitants from place to place in order to acquire resources, the group would live in sedentary or semi-sedentary homes. 
Resources would then be procured locally by the entire group, or regionally by small parties sent on hunting or gathering expeditions.

The Late Archaic stage, 3,000-200 B.P., is marked by this shift towards sedentism. Housepits occur more frequently, becoming common by the later part of this period. Earlier housepit sites in the Pacific Northwest occur in small clusters, with villages forming later in time. In the Gorge, two morphologically distinct housepit remains have been recorded: the relatively small oval and circular housepits with shallowly excavated floors, which are associated with the mat lodges of the Sahaptin-speaking culture groups of the Columbia Plateau, and larger square housepits, often with more deeply excavated floors, which are associated with the coastal Chinook-speaking peoples. The lower reaches and mouth of the Columbia River appear to have been inhabited almost exclusively by the Chinookans, while the area near the confluence of the Deschutes and Columbia rivers seems to have been occupied by Sahaptin groups. Very little is known at this time about the spatial and cultural relationships between the Chinookans and the Sahaptins within the Gorge.

The development of food storage was an essential component of sedentism in the Pacific Northwest and along the Columbia. Salmon, biscuitroot, and camas were the principal staples of the local diet in the Gorge. These were reliable, easily procured resources which were acquired seasonally, and their storage assured both large and small groups of subsistence throughout the winter.

Salmon preservation was observed by Lewis and Clark in the autumn of 
1805 just upriver from The Dalles:

...about their Lodges I observe great numbers of Stacks of pounded Salmon butifully preserved in the following manner, i.e., after Suffiently Dried it is pounded between two Stones fine, and put into a species of basket neetly made of grass and rushes of better than two feet long and one foot Diamiter, which basket is lined with the Skin of Salmon Stretched and dried for the purpose, in this it is pressed down as hard as is possible, when full they Secure the open part with the fish Skins... then on a Dry Situation they Set those baskets the Corded part up, their common Custom is to Set 7 as close as they can stand and 5 on the top of them... those 12 baskets of from 90 to 100 [pounds] each [basket] form a Stack. thus preserved those fish may be kept Sound and Sweet Several years, as those people inform me, Great quantities as they inform us are Sold to the white people who visit the mouth of this river as well as to the nativs below (Moulton 1988, 325).

With the establishment of sedentism and food storage, local populations within the Gorge expanded and their cultural traditions flourished. During the Late Archaic, the bow and arrow were in common use by about 2,000 B.P. Villages were established, and the artistic traditions which were later documented by ethnographers reached their widest expression. The area in and around The Dalles, primarily on the north side of the river, became the center of an extensive trade network. Lewis and Clark noted that the local people traded their preserved salmon downstream to European trappers and explorers at the mouth of the Columbia as well as to other native people. In fact, the native fishery at Celilo Falls and Fivemile Rapids, possibly the single most productive fishery on the Columbia, was the site of seasonal trade fairs during the salmon harvests, attracting many different groups from the entire Pacific Northwest and as far away as the Great Plains. At least 3,000 people were observed at one such fair in early 
historic times (Aikens 1986), and many more may have attended in the late prehistoric period, before the decimation of these native populations by European-introduced diseases.

Information concerning the Late Archaic period in the Gorge comes primarily from the salvage and mitigation efforts associated with the construction of the Bonneville and The Dalles dams. Sites which were excavated at The Dalles Dam include the Fivemile Rapids site, as well as Wakemap Mound, a village and midden site near present-day Horsethief Lake State Park in Washington. Housepit remains from a Sahaptin mat lodge village in the oldest stratum of the mound were dated to approximately 1,090 B.P., with continuous occupation until at least 560 B.P. A second, less well-defined village was superimposed over the older village, and has been dated to about 200 B.P. The artifacts recovered from Wakemap Mound included many heavily and elaborately decorated items such as pipes, unfired clay figures, pendants, and stone bowls and mortars.

\section{ROCK ART OF THE GORGE}

In conjunction with the florescence of regional artistic traditions during the Late Archaic was the creation of the rock art of the Dalles-Deschutes area. McClure's 1984 thesis suggests that while some rock art may date to as early as 3,500 B.P., the majority was probably produced after 1,250 B.P. Although the stylistic motifs of the rock art combine elements of both Chinook and Sahaptin artistic traditions, reflecting the intermingling of these two groups in the Gorge, 
the dominant stylistic influence comes from the Sahaptin groups of the Columbia Plateau. This includes the use of rayed arc and rayed circle pictographs, often in two or more colors, and the occurrence of common motifs such as mountain sheep. Coastal influences from Chinook-speaking people involve the use of curvilinear and often highly stylized figures of animals (zoomorphs) and people or spirits (anthropomorphs). The Tsagiglalal image (Fig. 3) is an example of this style.

Most of the rock art in the Columbia River Gorge National Scenic Area is located near the confluence of the Deschutes and Columbia rivers, on the Washington shore from Miller Island to the now-submerged Fivemile Rapids. One of the largest concentrations of rock art in the Pacific Northwest occurred in Petroglyph Canyon, just above the head of Fivemile Rapids (Fig. 4). It is unclear from the descriptions of this site prior to inundation exactly how many separate petroglyphs occurred here, although McClure (1978) estimated no fewer than 450. Much smaller concentrations of rock art above the water line are present in and near Horsethief Lake State Park in Washington. McClure (1984) noted that most of the recording and documenting of the rock art in and around The Dalles has been accomplished by amateurs rather than by professional archaeologists. The lack of interest on the part of archaeologists may be attributed in part to the difficulty in dating rock art, as well as to the difficulty in relating it to items of material culture such as projectile points, house types, and other features and artifacts which much more concretely reveal how humans living in the past 


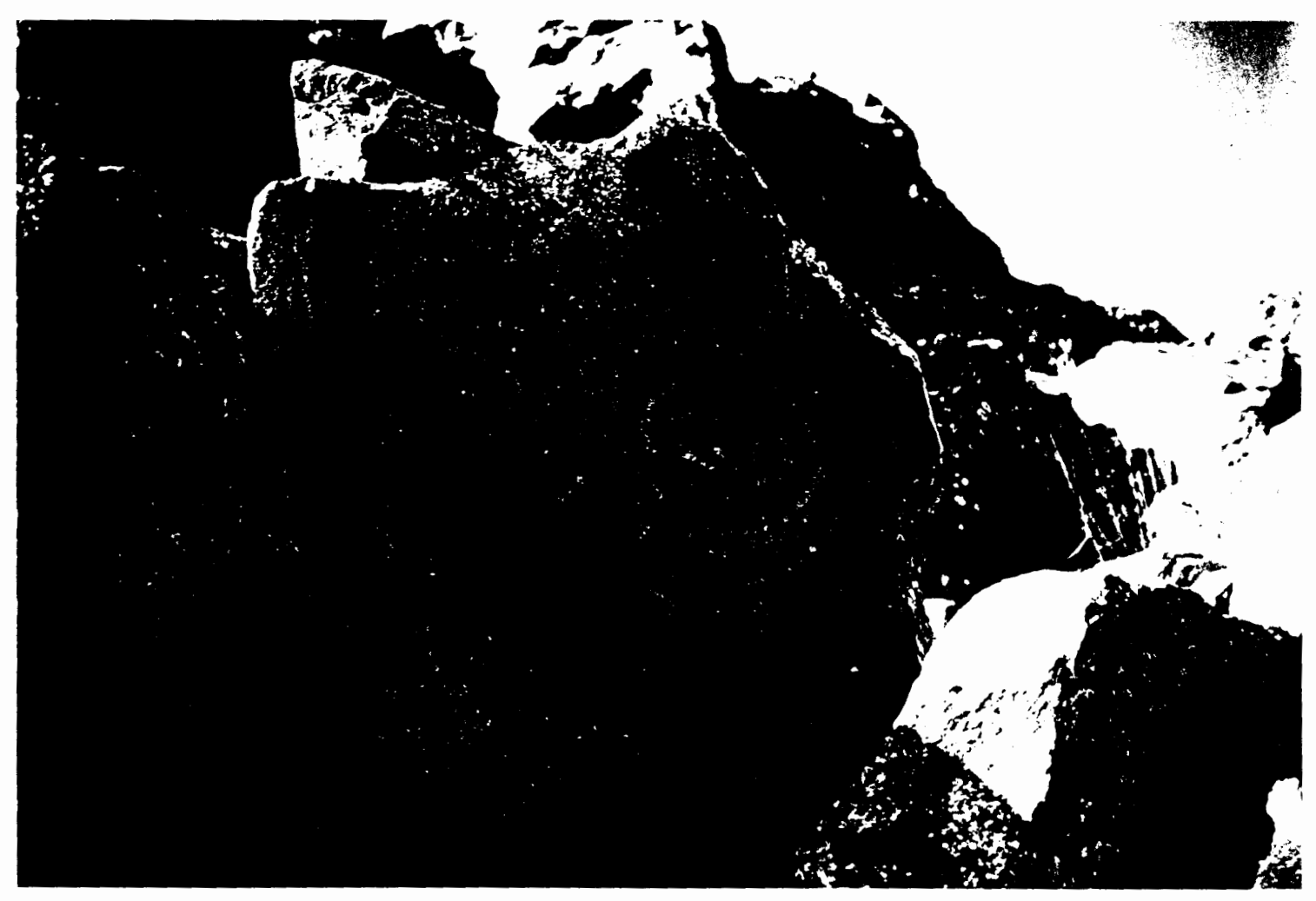

Figure 3. Tsagiglalal, or "She Who Watches", a petroglyph in the Columbia River Gorge National Scenic Area. 


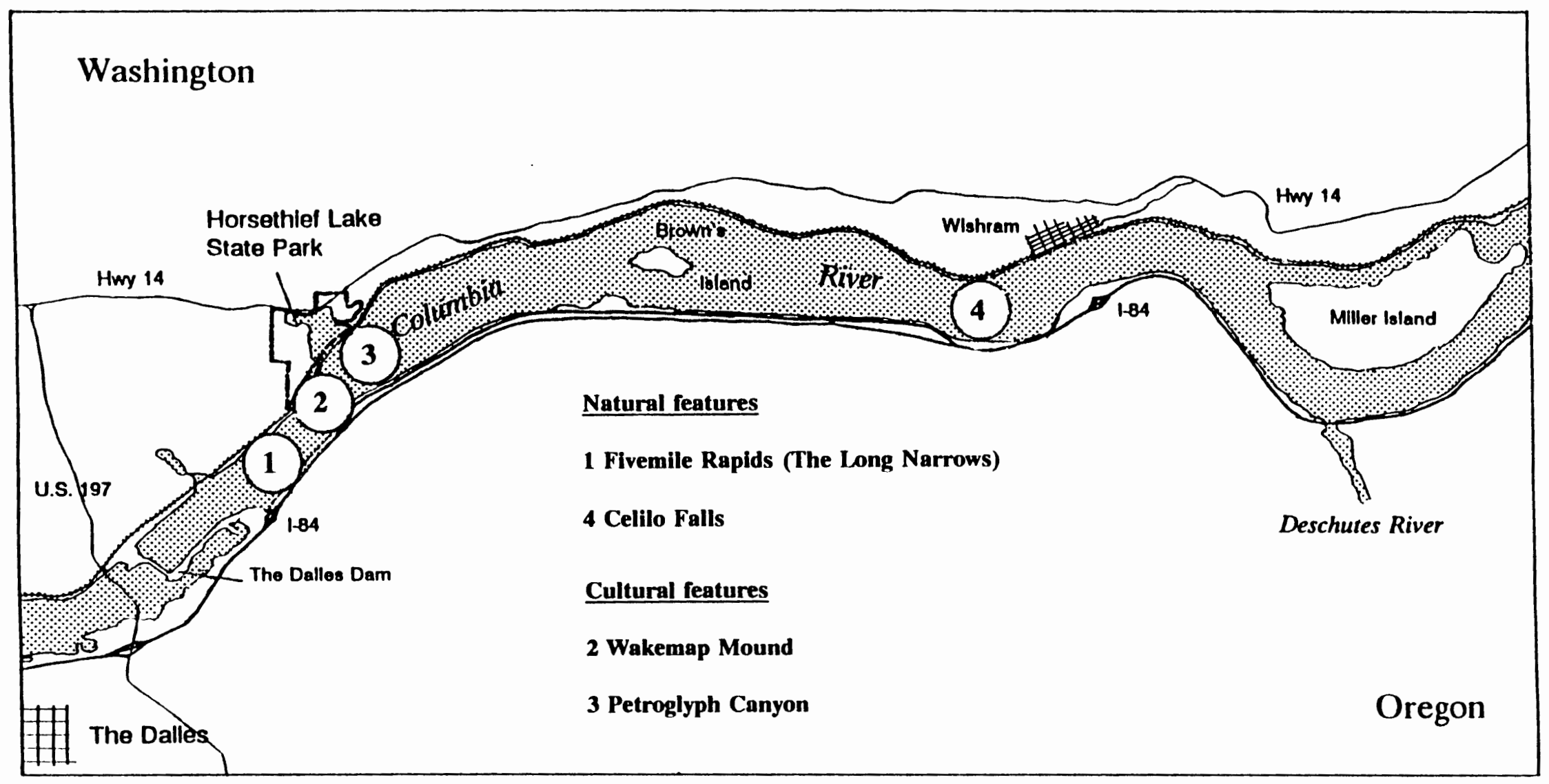

Figure 4. Natural and cultural features in the eastern portion of the Columbia River Gorge National Scenic Area. Base map compliled from USGS 7.5 quads. 
structured their lives. Rock art, as with all types of artistic expression, represents symbolically the non-material aspects of peoples' lives, such as ideology. Interpreting the function of an abstract image such as a petroglyph is therefore much more difficult than determining the function of an arrowhead or a stone bowl, which may explain why rock art was often overlooked by professional archaeologists.

\section{EURO-AMERICAN CONTACT AND SETTLEMENT}

Following the Late Archaic cultural florescence was the period of initial contact with Euro-American explorers and the expansion of Euro-Americans onto native lands. The process of European settlement and development profoundly affected the native populations residing in the Gorge, and precipitated changes in land use which would permanently alter the physical and cultural landscapes of this region, a process described in depth by Wilke et al. (1983) and Beckham (1988).

Lewis and Clark were the first documented group of Europeans to navigate the Columbia River in its inland passages. Coastal explorations had begun some years earlier, in the late 1700 s, but none sailed upriver beyond the Cascades. By the time Lewis and Clark arrived, however, the effects of these earlier explorers were already being felt among the native peoples of the coast and the lower Columbia. Epidemics caused by European diseases such as smallpox, influenza, and measles, decimated the tribes, which had no resistance to the exotic illnesses. 
Lewis and Clark noted the remnants of a large native village near present-day

Portland, and were told by one survivor that the smallpox had destroyed the village approximately 30 years earlier, and that this same epidemic had also destroyed the Clatsop nation (Wilke et al. 1983). Horatio Hale, another explorer in the area, described in 1846 the results of subsequent epidemics along the Columbia River between Multnomah Island and Celilo Falls:

At the period of the visit of Lewis and Clark, this was the most densely populated part of the whole Columbian region, and it so continued until the fatal year 1823, when the ague-fever, before unknown west of the Rocky Mountains, broke out, and carried off four-fifths of the population in a single summer. Whole villages were swept away, leaving not a single inhabitant. The living could not bury the dead, and the traders were obliged to undertake this office, to prevent a new pestilence from completing the desolation of the country. The region below the Cascades, which is as far as the influence of the tide is felt, suffered most from this scourge. The population, which before was estimated at upwards of ten thousand, does not now exceed five hundred (Wilke et al. 1983, 91).

Before another ten years had passed, the Yakima and Klickitat tribes which resided upriver near The Dalles were also nearly extinguished by repeated epidemics of smallpox.

As with other parts of the country, the depopulation of native tribes by introduced diseases facilitated the settlement and expansion of the Columbia River Gorge. Armed conflicts were largely avoided until 1856, when Indians attacked Fort Cascades and settlements on the north side of the river in the Gorge. The attacks were carried out by the survivors of repeated epidemics, who had also suffered Euro-American seizures of their lands and the failure of the treaties (Beckham 1988). The uprising did not last, but did increase pressure on 
the Indians to relocate to the Yakima and Warm Springs reservations.

The Donation Land Act of 1850 and the opening of the Oregon Trail immediately prior to the Land Act accelerated the rate of settlement, drawing settlers from the other side of the country, many of whom utilized the Gorge as a transportation conduit through the Cascades. According to Beckham (1988, 130, 154),

The [Donation Land Act] proved a significant factor in dispossessing Upper Chinookans on both margins of the Columbia from The Dalles to the Washougal River, especially along the north bank. . . . On the Oregon shore the Donation Land Act was of less significance. The pace of settlement moved slower on the south bank. The heavy shade, steep terrain, and attractive acreages in the upper Willamette, Umpqua, and Rogue valleys drew away many potential filers. The donation claims numbered only a dozen and were primarily at the mouth of Hood River and in the vicinity of The Dalles.

Treaty negotiations with the resident Indian tribes of the Columbia River Gorge began in the 1850 s, when the Oregon Territory was divided into northern and southern portions, with the Columbia River as the dividing line. The superintendent of Indian Affairs in Oregon, John Palmer, advocated treaties which would ensure what Beckham refers to as the "forced acculturation" of the Indians $(1988,130)$, removing them from their traditional lands and relocating them to reservations where they were to learn to live the "white man's" way. On the north side of the Oregon Territory, Issac I. Stevens was the superintendent of Indian affairs. Stevens employed the services of George Gibbs, a Harvard Law School graduate, in the design of Indian treaties. Gibbs was "convinced that Indian survival depended on their right to fish at usual and accustomed grounds and 
stations, included that language in the treaties which Stevens negotiated in 18541855" (Beckham 1988, 131). Following the ratification of these treaties, increased pressure was brought to bear on the various tribes to relocate to the Yakima and Warm Springs reservations, away from the "usual and accustomed" fishing stations. This pressure culminated in the Supplemental Treaty in 1865, which required the Warm Springs Indians to forego their off-reservation hunting and fishing rights on the Columbia River.

With the removal of the majority of the Indians to reservations, and with the creation of rail lines which linked the Gorge to Portland and to the Columbia Plateau, Euro-American settlement accelerated rapidly. The rail lines, and later the revival of river transportation, served not only to move people but commodities as well. The Columbia Plateau became an agricultural region specializing in wheat, and sent its harvest down the Columbia to Portland and on to the ocean-going ships on the coast.

Due to the enormous and consistent salmon runs and the invention of the canning process, the Columbia River became the home to a burgeoning commercial salmon industry between the 1860 s and the 1920s. The use of fishwheels and of Chinese labor enabled this industry to expand rapidly. Fishwheels could recover a massive amount of fish in a short time; in 1881, one such fishwheel took 10,000 salmon in a 24 -hour period, and 30 tons of sturgeon on a separate occasion (Beckham 1988). Canneries along the river needed a large volume of labor for processing such large amounts of fish, and found it in newly- 
arrived Chinese immigrants. With about 79 fishwheels deployed on the Columbia within the Scenic Area, overfishing was the inevitable result, and the salmon catch began to decline in the late 1890 s. As a result, fishwheels were banned in Oregon in 1926, and in 1935 in Washington (Beckham 1988).

Principal industries within the Scenic Area today include logging and lumbering, specialized agriculture such as orchards and berry cultivation, and tourism. Timber activities have been increasingly curtailed by environmental concerns and changes in local and world economies. Since 1958, commercial fishing between the Bonneville Dam and the McNary Dam has been the exclusive province of Indian treaty fishermen. Tourism, however, is currently expanding, and it is possible that tourism and recreation will be developed and promoted as a leading source of revenue. Windsurfing has already become an enormously popular activity in the Scenic Area, and may account for most of the total revenue generated by tourism and recreation activities in the Gorge. Windsurfers are also considered to be the primary cause of seasonal overcrowding at Scenic Area campgrounds (Morse and Anderson 1988). An analysis of visitor activities from 1982 to 1986 showed increased traffic levels on all major Gorge highways, while popular Gorge attractions such as Multnomah Falls and the Maryhill Museum also experienced a slow but steady increase in visitors during that time (Morse and Anderson 1988). The same analysis indicated that the main reason for visiting the Gorge was sightseeing, while the second most common reason was to visit unspecified historic sites. 
The largest community in the Scenic Area is The Dalles, Oregon, with a 1990 population of 11,060 . Smaller communities on the Oregon side include Hood River, with a population of 4,632, and towns such as Mosier, with a population of 244. In Washington, towns vary in size from 6,114 at White Salmon to 645 at Bingen.

The diverse natural, cultural, and scenic resources in the Gorge have been managed by individuals as well as by state and federal governments during the last century. The rapid pace of development and the growing population eventually led to the passage of the Columbia River Gorge National Scenic Area Act in 1986, which provides a uniform management plan throughout this region. 


\section{CHAPTER IV}

\section{LAND OWNERSHIP AND MANAGEMENT}

Of the many federal, state, and private owners and managers of land in the Gorge, the federal presence is the most extensive and apparent. From the Lewis and Clark expedition in $1805-1806$, to the creation and implementation of the Scenic Area Act in 1986, federal land use and economic development have been major forces in the region. In terms of the effect upon the landscape of the Gorge, the largest federal impact has been the construction of the dams at Bonneville and at The Dalles by the U.S. Army Corps of Engineers. The Bonneville Dam was designed to provide hydroelectric power to the growing urban center in Portland, and was completed in 1937. Today, the Bonneville Dam has two powerhouses whose combined output is over one million kilowatts. This electricity is marketed in the Pacific Northwest and parts of California. The dam complex includes two navigation locks, fish hatcheries, fish ladders, and a visitor center. The Bonneville Lock and Dam Project was placed on the National Register of Historic Places in June of 1986 as an historic district.

The Dalles Dam was also built to provide hydropower, with recreation and improved navigation on the Columbia as by-products of its construction. The dam was completed in 1957 , and has a 22 -generator powerhouse which provides almost two million kilowatts of electricity. Other facilities include two fish ladders, one 
navigation lock, a tour train, and a park and visitor center.

Another federal agency which plays a major role in the development and management of the Scenic Area is the USDA Forest Service ("Forest Service"). Since its inception in 1906, the Forest Service has managed the two national forests in the Scenic Area, known today as the Gifford-Pinchot National Forest in Washington and the Mt. Hood National Forest in Oregon. Besides administering the many duties associated with forest management, the Forest Service also oversees the construction and upkeep of numerous tourist facilities, including the facilities at Multnomah Falls, which was built by the city of Portland and donated to the Forest Service (and is the most popular of all tourist destinations in the Gorge), the Eagle Creek trails and campground, and numerous other picnic areas, campgrounds, trails, and ranger stations. With the Forest Service as the largest federal land manager in the Columbia River Gorge, it was inevitable that it be designated one of the major players in the development of the management plan for the Scenic Area.

Washington and Oregon are also key land owners and managers in the Scenic Area. Like the Forest Service, the states are responsible for the development and maintenance of parks and other recreation facilities, as well as the highways, bridges, and attendant rights-of-way. The more popular parks include Crown Point, Rooster Rock, Lewis and Clark, Memaloose, Deschutes, and Horsethief Lake.

Local (city and county) land ownership and management takes place 
primarily within Urban Areas designated by the Columbia River Gorge

Commission, which excludes them from the Management Plan for the Columbia River Gorge National Scenic Area.

Finally, over 50,000 people live within the boundaries of the Scenic Area, and many of them own property. There are also numerous businesses and utilities which operate in the Gorge, and they too affect and are affected by Scenic Area legislation.

These often competing agencies and individuals (summarized in Table II) have been brought together under one management plan as a result of the Columbia River Gorge National Scenic Area Act, which was signed into law in 1986. The purpose of the Act is

To establish a national scenic area to protect and provide for the enhancement of the scenic, cultural, recreational, and natural resources of the Columbia River Gorge; and

To protect and support the economy of the Columbia River Gorge area by encouraging growth to occur in existing urban areas and by allowing future economic development in a manner that is consistent with paragraph 1 [above] (Management Plan for the Columbia River Gorge National Scenic Area 1992, 2).

The Management Plan also describes the three types of land and water within the Scenic Area:

Thirteen cities and towns designated as Urban Areas: North Bonneville, Stevenson, Carson, Home Valley, White Salmon, Bingen, Lyle, Dallesport, and Wishram on the Washington side of the river and Cascade Locks, Hood River, Mosier and The Dalles on the Oregon side. The Urban Areas encompass about 28,511 acres. They are exempt from the Management Plan, but are eligible to receive federal funds authorized to implement it. The Urban Areas 


\section{DESCRIPTION OF THE RESOURCE MANAGEMENT ENTITIES IN THE COLUMBIA RIVER GORGE NATIONAL SCENIC AREA}

\section{Manager}

\section{The Gorge Commission}

Composed of 12 voting members appointed by the two state govenors and the six counties. Also included is one non-voting member from the Forest Service, appointed by the Secretary of Agriculture.

\section{The Forest Service}

\section{Function}

Responsible for the development of the Management Plan for the General Management Areas within the Scenic Area. Oversees the General Management Areas and other nonfederal lands. Other duties include ensuring compliance with the Management Plan, revising the Management Plan, changing Urban Area boundaries, and hearing the appeals of county decisions.

Manages the two national forests within the Scenic Area: the Gifford Pinchot in Washington and the Mt. Hood in Oregon.

Acquires additional federal lands within the Scenic Area through purchase, exchange, donation, or condemnation. Management of these federal lands, of the White Salmon and Klickitat Wild and Scenic Rivers, and of the two national forests is carried out by the National Scenic Area Forest Service administrative unit in Hood River, Oregon.

Provides technical support for state and local governments on non-federal lands.

Administers the distribution of of the $\$ 32.8$ million authorized by Section 16 of the Scenic Area Act. These funds are earmarked for continuing land acquisitions, and economic and recreation programs.

Monitors county Management Plan implementation actions in the Special Management Areas (SMAs).

Monitors the scenic, cultural, recreation, and natural resources of the Scenic Area. 


\section{TABLE II}

\section{DESCRIPTION OF THE RESOURCE MANAGEMENT ENTITIES IN THE COLUMBIA RIVER GORGE NATIONAL SCENIC AREA \\ (continued)}

Manager

\section{Washington and Oregon}

The six counties: Clark, Skamania, and Klickitat in Washington; Multnomah, Hood River, and Wasco in Oregon

\section{Function}

State agencies were involved in collecting data for the natural and cultural inventories. This data was used in drafting the Management Plan.

Appoint members to the Gorge Commission.

State land use laws and state laws designed to protect natural and cultural resources remain in effect.

The State Historic Preservation Office (SHPO) is given the opportunity to review all cultural resource surveys, evaluations, assessments, and mitigation plans for proposed development in the Scenic Area.

Appoint members to the Gorge Commission.

Are responsible for the implementation of the Management Plan by adopting local land use ordinances consistent with the provisions of the Plan. These ordinances must be approved by the Gorge Commission.

Review proposed land uses on lands not administered by the Forest Service to determine if these uses are consistent with the regulations and provisions of the Management Plan.

Make the final decision which determines whether a proposed land use complies with the cultural resource goals, policies, and guidelines of the Managment Plan, as well as complies with Indian treaty rights. 
TABLE II

\section{DESCRIPTION OF THE RESOURCE MANAGEMENT ENTITES IN THE COLUMBIA RIVER GORGE NATIONAL SCENIC AREA}

(continued)

\section{Manager}

Indian governments: the $\mathrm{Nez}$ Perce Tribe, the Confederated Tribes of the Yakima Nation, The Confederated Tribes of the Warm Springs of Oregon, and the Confederated Tribes of the Umatilla Reservation.

\section{Function}

Consultants in the development of the Management Plan.

Must be notified of proposed developments on public land, and on or adjacent to the Columbia River and any tributaries that support anadromous fish. Such developments must avoid impacting treaty rights.

Must be consulted when cultural resource surveys, evaluations, assessments, and mitigation plans are conducted when the cultural resources in question are prehistoric or otherwise associated with Native Americans. 
will be the primary focus for future growth and economic development.

The Special Management Areas includes 115,100 acres of the region's most sensitive lands, concentrated primarily in the western half of the Scenic Area. The U.S. Forest Service was directed to prepare land use designations and guidelines for the SMA. It was given authority to purchase lands, or interests in lands, in the SMA, and the opportunity to exchange federal lands elsewhere for privately held forest lands within SMA boundaries.

The remainder of the Scenic Area makes up the General Management Areas, which totals 149,004 acres and includes the Columbia River. The Gorge Commission was authorized to plan for the GMA. These lands blanket most of the eastern Gorge and are scattered in the central west end of the Gorge. They are predominantly devoted to agricultural and forestry uses, but also contain scattered areas of existing residential development (3).

The overall management plan for the Scenic Area was recently completed in September 1992, and considers the two states and six counties within the Scenic Area as a single region. The Forest Service and the Gorge Commission, which is composed of representatives from the two states and the counties, were responsible for drafting the plan. The counties will be required to implement the plan in land use ordinances.

While the Scenic Area management plan does not supersede state and federal laws and regulations, it does supplant the management plans of all the other agencies and individuals within the Scenic Area. This is the first time in the history of the Gorge that a single plan has been developed to manage the natural and cultural resources of the area, whether they are owned by the states, local governments, the federal government, or private citizens and businesses. 


\section{CURRENT STATUS OF THE ROCK ART AS A CULTURAL RESOURCE}

The status of the rock art in the Columbia River Gorge rests largely on land ownership and management. Numerous state and federal laws have been developed to protect archaeological sites on public land, and a few offer protection to sites on private land. But the implementation of these laws, as well as the internal policies of the various land managers, can vary widely. Laws affecting the preservation of cultural resources have evolved slowly. In the early 1900s, only one law, the 1906 Antiquities Act, was in effect at the federal level (and none at the state level) to protect archeological sites. This law prohibits the destruction or excavation of historic or prehistoric sites on federal land without government permission. It does not require federal agencies to inventory the cultural resources under their jurisdictions, nor does it require the funding of mitigation efforts for sites which are threatened by development. Gorospe (1985) notes that this law was designed primarily for the protection of archaeological sites which were thought to be of outstanding national interest, and which had been declared national monuments, such as the cliff dwellings at Mesa Verde, Colorado.

The Historic Sites Act was enacted in 1935. It is aimed primarily at preserving historic sites for public benefit, but also offers some protection to prehistoric sites. The goal of this law is to acquire the property on which sites are located, and restore and maintain the sites as necessary in order to preserve them for the public. This also applies to sites jeopardized by federal construction projects. Funding for any required mitigation is to come from either the federal 
agency responsible for the construction or from Congressional appropriations.

Nineteen thirty-five was also the year in which Oregon first passed legislation protecting cultural resources. Oregon state law ORS 358.905 - ORS 358.955 parallels the federal law, requiring a permit to excavate or otherwise disturb historic or prehistoric remains located on state land. No direct penalties are imposed for breaking these laws, but any artifacts illegally recovered become the property of the government.

Further federal protection of cultural resources came with passage of the National Historic Preservation Act (NHPA) in 1966, the National Environmental Policy Act (NEPA) of 1969, the Archeological and Historic Preservation Act (AHPA) of 1974, and the Archeological Resources Protection Act (ARPA), passed in 1979 and amended in 1988. These first three require that steps be taken to protect archaeological resources from the effects of development, while ARPA specifically targets the threat to sites from vandalism, imposing significant criminal penalties for

the vandalism, alteration, or destruction of historic and prehistoric sites on Federal and Indian lands, as well as for the sale, purchase, exchange, transport, or receipt of any archaeological resource if that resource was excavated or removed from public lands or Indian lands or in violation of State or local law (Carnett 1991, 2).

NEPA, NHPA, and AHPA provide protection for archaeological resources which are threatened by federally-funded construction projects or activities. These may occur on state, federal, or privately owned lands, and include projects such as the construction of interstate highways, reservoirs, and pipelines. In addition, these 
laws require federal agencies to maintain accurate and current inventories of known cultural resources, and information on the nature, extent, and significance of these resources (Minor 1988).

Washington state provides legal protection of archaeological sites on private land as well as state land. Title $27 \mathrm{RCW}$, Chapter 27.53, Archaeological Sites and Resources, paragraph .060 , states that

On the private and public lands of this state it shall be unlawful for any person, firm, corporation, or any agency. .. to knowingly remove, alter, dig into, or excavate. . . or to damage, deface, or destroy any historic or prehistoric archaeological resource or site, or remove any archaeological object from such site. . . or any glyptic or painted record of any tribe or peoples, or historic graves. ...

Indian burials, whether on public or private land, are accorded similar protection under a separate statute.

Current Oregon state law, ORS 358.905 - ORS 358.955, prohibits the excavation, injury, destruction, or alteration of an archaeological site on state land without a permit. It further prohibits the sale or purchase of artifacts taken from public land, or from private land without the written permission of the landowner. Similar to Washington state law, Indian burials in Oregon are covered under a separate statute, and are extended similar protection.

Unlike Washington, however, in Oregon it is still legal for a landowner, or someone with permission from the landowner, to excavate artifacts and sell them. This illustrates an important issue in archaeological preservation: that most sites on private land in this country have no legal protection from looting and vandalism. Knudson $(1991,72)$ explains that "in the United States, archaeological 
resources are traditionally assumed to accompany the title to land surface rights". According to Carnett (1991, 6-7), only 14 states extend legal protection to cultural resources which occur on private land: "Unlike European nations, the United States has not embraced the concept of a national cultural heritage law that protects significant resources within the boundaries of private ownership of land". Since most archaeological sites in this country are located on private land, they are largely unprotected against surface collection, excavation, or vandalism.

The cultural resource protection laws cited above have been drafted to prevent the kind of looting which occurred during the construction of The Dalles Dam in the 1950s. In spite of the archaeological richness of the sites at the dam, which included Wakemap Mound, a good deal of valuable information was lost because of looting. Work at the dam sites began in 1953 and continued intermittently through 1957 . Due to a chronic lack of funding with which to hire experienced archaeologists, amateur relic collectors (also known as "pothunters") were allowed to participate in the excavations in order to provide much-needed labor. However, the collectors far outnumbered the archaeologists, and demanded to keep the artifacts they found. At this same time, the realization that the archaeological sites located in the pool area behind the dam would soon be under water spurred feverish pothunting activity. A sort of looting free-for-all ensued at Wakemap and other sites. According to Minor (1988), at least one D-8 bulldozer with a 4.5-meter blade was used by looters to cut swaths through a cremation site. In another instance hydraulic mining equipment was utilized to wash artifacts from 
the cultural deposits in the soils at the dam site. This kind of wholesale looting continued until the archaeological sites were drowned by the impounded Columbia River.

In fact, collecting artifacts from private and public lands has been a favorite recreational activity along the Columbia in the Dalles-Deschutes area since the turn of the century. Duncan's report (1979) found that local residents living near Horsethief Lake State Park have been surface collecting since the early 1900s, and that newspapers in Lyle and The Dalles from this time period "describe the area as 'a rich hunting ground for artifacts' " (38). Recreational surface collecting continued through the 1950 s, at which time collectors began to excavate in large numbers, culminating in the activities described above. Today, vandalism of rock art and illegal excavations and collections still occur in and around Horsethief Park and elsewhere within the Scenic Area. Many looters are now professional pothunters rather than people enjoying a recreational activity, and receive high prices for their artifacts on an illegal international market. Pothunters often seek out rock art to guide their excavations, acting under the assumption that where there is rock art, there are bound to be artifacts. As a result, it is not uncommon to find looter's pits at the base of the basalt cliffs at rock art sites (Fig. 5).

In spite of a surfeit of federal and state laws which protect cultural resources, archaeological sites in the Scenic Area are impacted almost daily from the activities of both professional looters and those seeking to recover an attractive artifact to take home. Implementation of the laws often rests on 


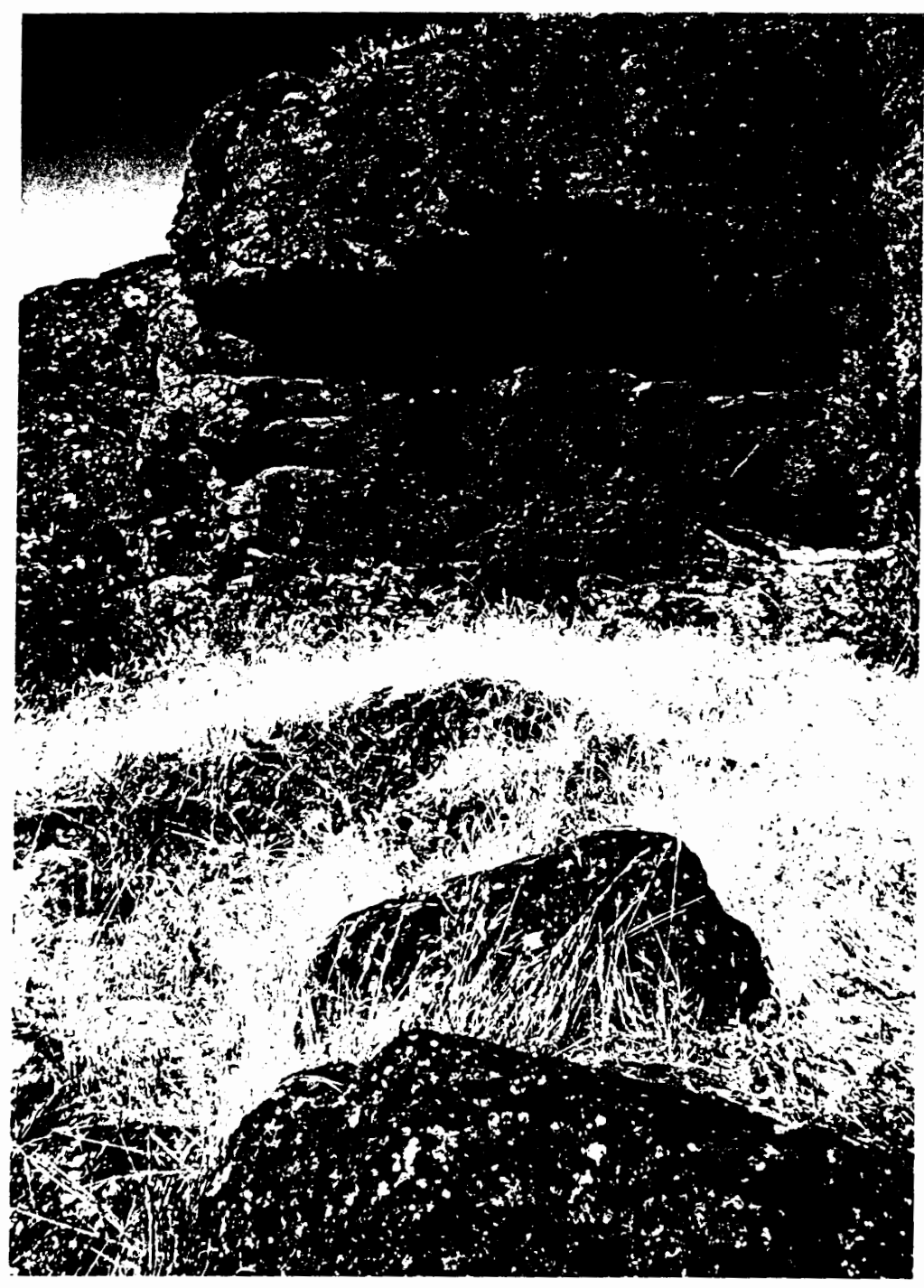

Figure 5. Looter's pits, dug at the base of a rock art site in the Columbia River Gorge National Scenic Area. 
underfunded and overburdened law enforcement officials who are further hampered by the inaccessibility of the sites. In the case of the sites at Horsethief Lake State Park, enforcement and protection have languished in large part because of the conflicts between the U.S. Army Corps of Engineers (the "Corps"), which owns the park property, and Washington State Parks, which leases it from the Corps. Recommendations from park personnel and professional archaeologists regarding the protection of the many sites on the property have not been implemented due to lack of funding and bureaucratic inaction (Freed 1989).

The result of the failure to enforce the cultural resource protection laws is continuing vandalism over time. This has recently become most apparent to the rock art in Horsethief Park, where acts of vandalism increased substantially in the spring and summer of 1992 (Figs. 6 and 7). However, the damage was sufficient to attract the attention of the major players in the park's management: The Gorge Commission, the Corps, Washington State Parks, and the Yakima and Warm Spring tribes. As of October 26, 1992, the public will no longer be allowed unrestricted access to the rock art at the park.

The closure of the rock art site at the park highlights the contrast between the two different types of cultural resource management: regulatory management, which regulates development and its impacts on cultural resources, and prohibitive management, which targets non-development impacts such as vandalism. Prohibitive management is primarily a function of law enforcement, implemented by park rangers, county sheriffs, and other law enforcement personnel, while 


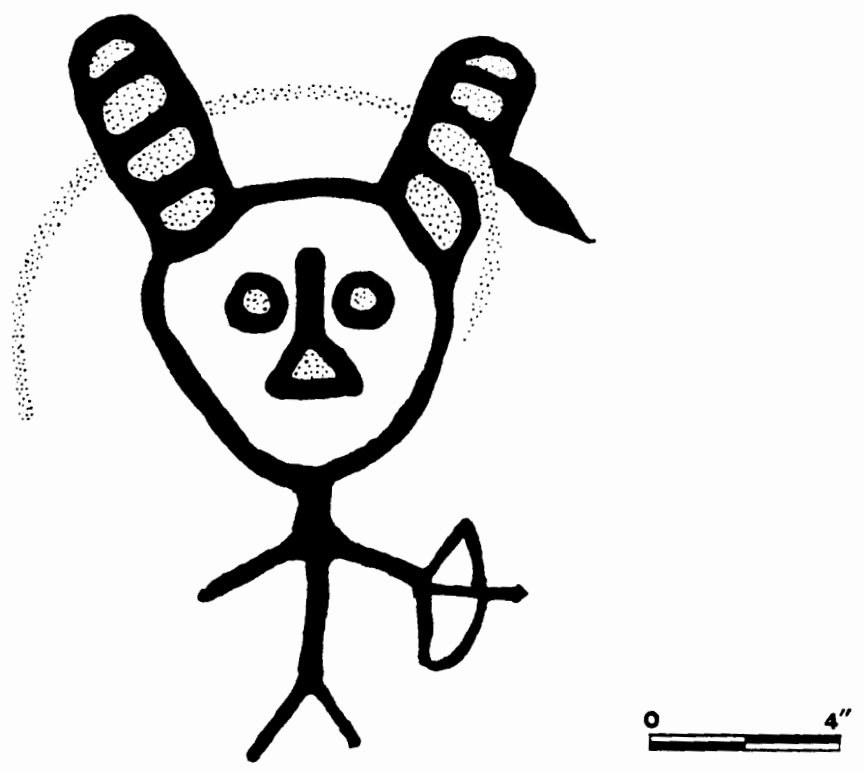

A. Pictograph at Horsethief Lake State Park, Washington, before vandalization.

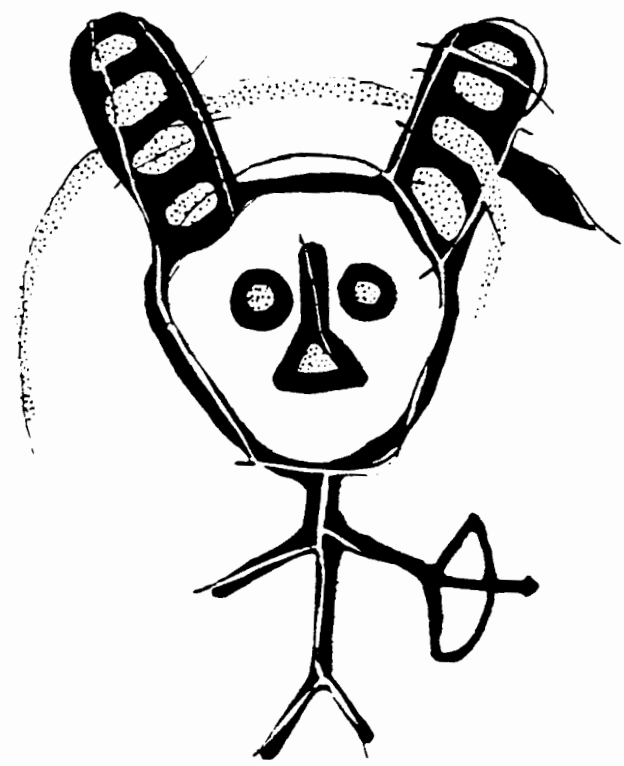

B. Pictograph after vandalization during the summer of 1992.

Figure 6. A red and white pictograph at Horsethief Lake State Park, Washington, A) before vandalization, and B) after vandalizaton. Illustrations by Eric Carlson. 


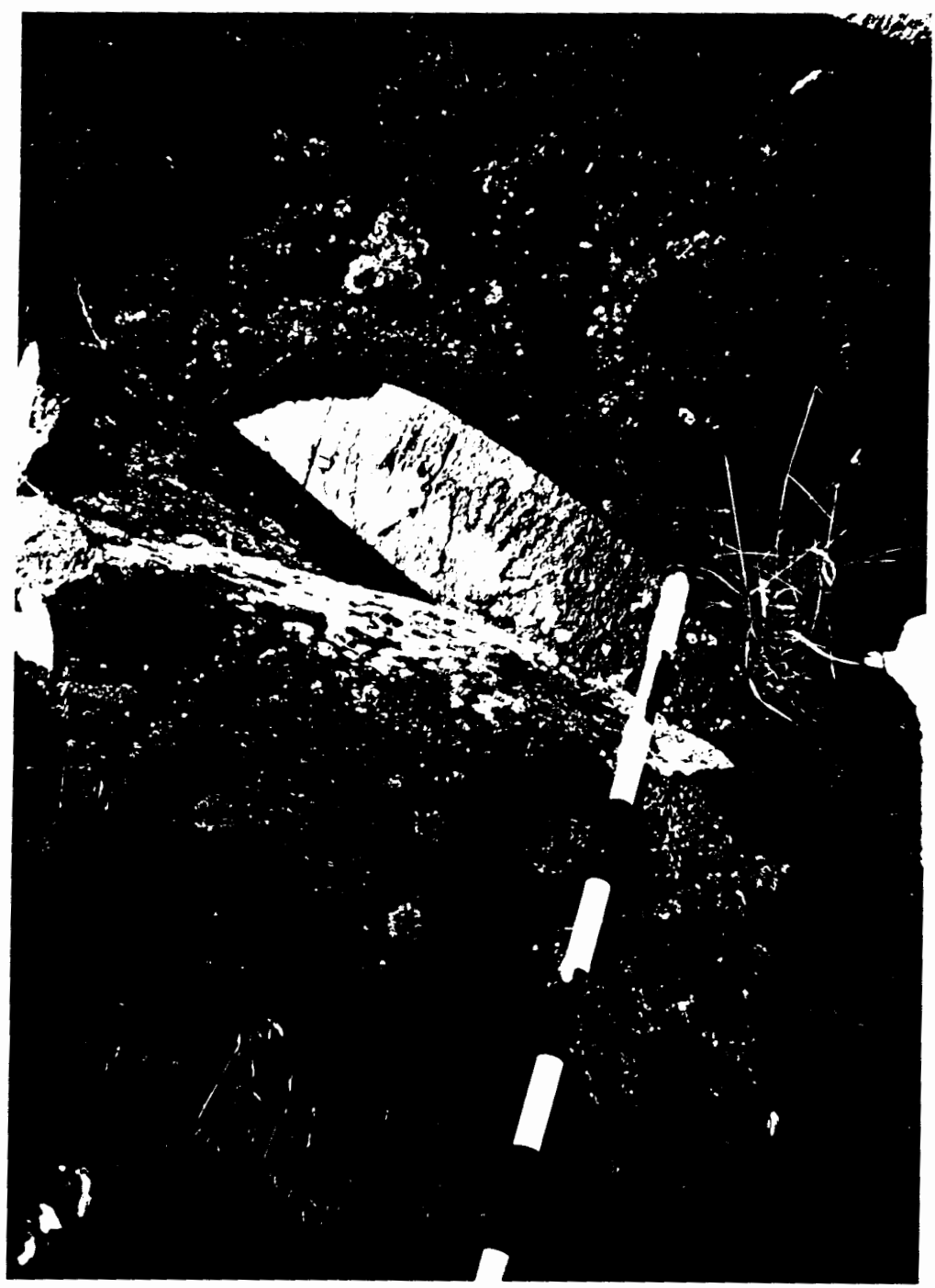

Figure 7. An example of vandalism which occured in Horsethief Lake State Park, Washington, in the summer of 1992. 
regulatory management is designed and implemented by planners, archaeologists, and other resource managers. Although the two types of management were designed to protect the same resource, they exist largely as separate entities. Failure to incorporate both types of management into a resource management plan often leads to crisis management of archaeological sites which are vandalized, as is the case with the rock art at Horsethief State Park.

Within the Scenic Area as a whole are approximately 156 known prehistoric archeological sites (Fig. 8). (Because less than 10 percent of the Scenic Area has been inventoried for cultural resources, these 156 sites represent a small fraction of the sites which are thought to exist in this area.) There are some 44 non-inundated rock art sites, 23 in General Management Areas (GMAs), 13 in Special Management Areas (SMAs), and seven in Urban Areas (UAs).

The Management Plan for the Columbia River Gorge National Scenic Area (1992) contains regulations for cultural resources in the GMAs and SMAs. (Cultural resource provisions and guidelines are summarized in Table III.) GMA goals are to 1) protect and enhance cultural resources, and 2) ensure that proposed uses do not have an adverse effect on significant cultural resources. GMA policies have been patterned after 36 CFR 800 of the National Historic Preservation Act (NHPA), calling for consultations with tribal governments during cultural resource surveys, evaluations, assessments, and mitigation plans involving prehistoric sites. The Gorge Commission is to create a Cultural Advisory Committee (CAC) to oversee the above processes, provide technical assistance, 


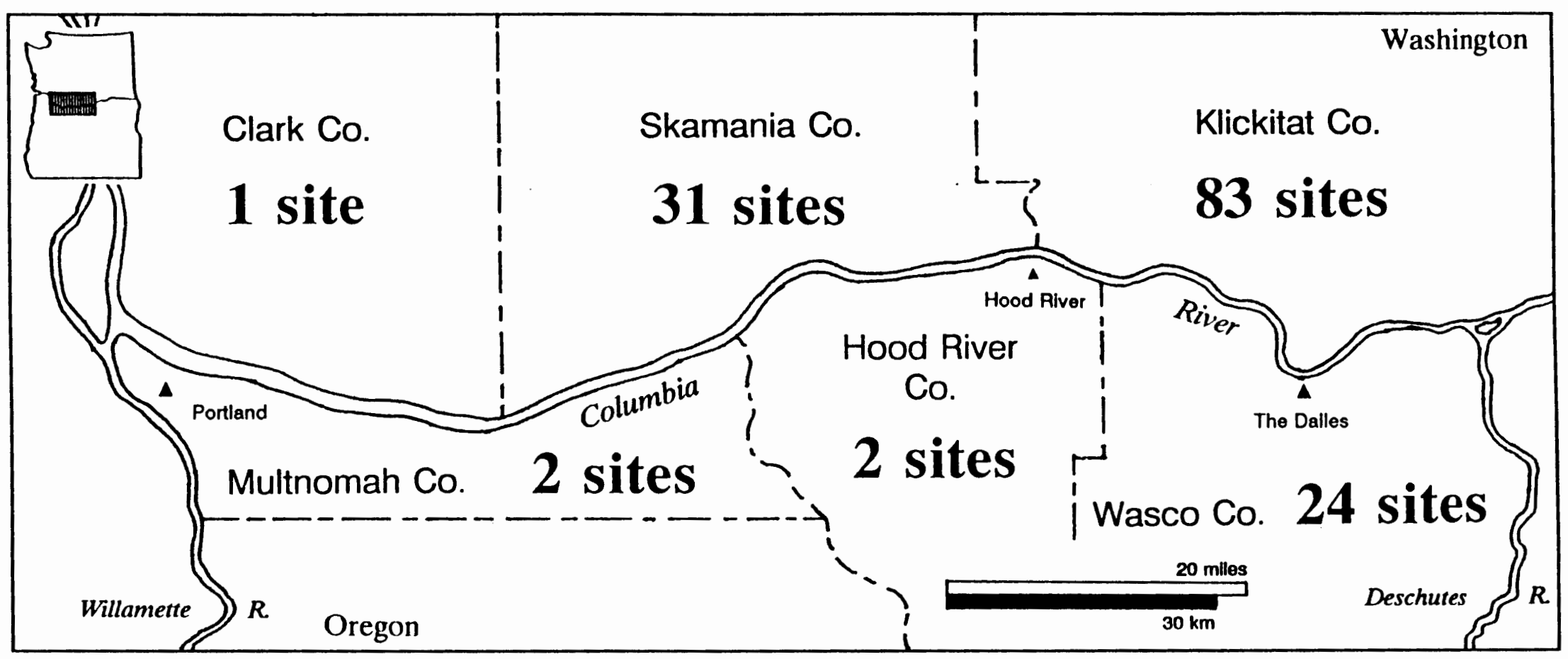

Figure 8. The 156 prehistoric archaeological sites in the Columbia River Gorge National Scenic Area, by county. Base map from Beckham et al. (1988). 
TABLE III

\section{SUMMARY OF THE CULTURAL RESOURCE PROTECTION PROVISIONS AND GUIDELINES FOR THE GENERAL MANAGEMENT AREAS OF THE COLUMBIA RIVER GORGE NATIONAL SCENIC AREA}

\section{Provisions}

Are applicable to development on public and private lands in the General Management Areas (GMAs), and to non-federal development in the Special Management Areas (SMAs).

Are based on Section 106 of the National Historic Preservation Act of 1966. They also conform to state and federal cultural resource protection laws.

The protection of cultural resources involves:

1) requiring cultural resource surveys before new developments are approved, unless the proposed development would have little or no impact on cultural resources;

2) Evaluating the significance of any cultural resources discovered during the surveys.

3) Assessing and documenting the effects of the proposed development on cultural resources.

4) Drafting mitigation plans to avoid impacting the cultural resources.

\section{Guidelines}

Cultural resource surveys are to include a surface survey and subsurface testing. Use of archival research, maps, description of the study area, methodology, inventory of any cultural resources located during the survey, and preliminary assessment of impacts are described and explained for inclusion in the survey report. Local governments must notify Indian tribal governments when a cultural resource survey is required.

Evaluation of the significance of cultural resources located during a survey is based on federal guidelines embodied in NHPA, and on Washington and Oregon State Historic Preservation Office (SHPO) guidelines. Indian tribal governments are to be consulted as needed.

Criteria for the assessment of the effect of a potential development on cultural resources follows 36 CFR 800 of NHPA. Assessments will determine whether the proposed development will have 1) no effect, 2) no adverse effect, or 3) an adverse effect. Adverse effects are defined as those that "diminish the integrity of the cultural resources when they alter or destroy characteristics of the resources that make them significant" (The Gorge Commission 1992, I-63). Assessments will take into consideration the concerns of Indian tribal governments. 
TABLE III

\section{SUMMARY OF THE CULTURAL RESOURCE PROTECTION PROVISIONS AND GUIDELINES \\ FOR THE GENERAL MANAGEMENT AREAS OF THE COLUMBIA RIVER GORGE \\ NATIONAL SCENIC AREA \\ (continued)}

\section{$\underline{\text { Provisions }}$}

Consultation with "tribal governments, social and cultural groups, and interested persons" (The Gorge Commission 1992) is required in conjunction with all provisions.

A Cultural Advisory Committee (CAC) will be established to monitor the implementation of the cultural resource protection regulations and provide technical assistance to local governments and landowners. In the event of disagreements between a project applicant's evaluation of the significance of cultural resources and the Indian tribal government's evaluation, the $\mathrm{CAC}$ will issue a recommendation to the local government with its own evaluation of significance.

\section{Guidelines}

Mitigation plans are to reduce an adverse impact to no impact or no adverse impact. Avoidance of cultural resources is the preferred means of mitigation. Alternative means are to be employed only if avoidance is not practicable. Alternatives can include burial under fill, removal to a safer place, and excavation. Plans for mitigation must be carried out in consultation with Indian tribal governments. 
and arbitrate conflicts that may arise. Detailed instructions covering almost every conceivable aspect of the protection of cultural resources which may occur on GMA lands slated for proposed development are provided, and include: determining when a cultural resource reconnaissance survey is necessary on GMA lands; determining who may conduct the reconnaissance; evaluating the results of the reconnaissance; determining which local, state, and tribal agencies are to be involved; determining the significance of cultural resources discovered during the reconnaissance; deciding who has final decision-making authority; assessing the effects of proposed development on cultural resources; developing mitigation plans for significant cultural resources which occur in areas of proposed development; implementing procedures for the discovery of human remains; and implementing procedures to be followed in the event of discovery of cultural resources during development. These exhaustive regulations address threats to cultural resources which arise from proposed development, but do not address issues of ongoing impacts which are not related to development, such as vandalism.

SMA lands have their own set of policies and guidelines for project review, based upon the same NHPA regulations as the GMAs. The stated goal for cultural resources on SMA lands is to "protect and enhance cultural resources" (p. I-69). The major difference between SMA and GMA regulations is the involvement of the Forest Service, in consultation with Indian tribal governments. The Forest Service is responsible for assessing potential effects to cultural 
resources located on national forest land, and privately owned forest land, and must also review mitigation plans which are developed for these sites. Other federal land managers, such as the Corps, must follow the same guidelines for assessing potential effects to cultural resources located on their lands. Sites which occur on privately owned land within the SMAs will be managed according to the GMA guidelines. These guidelines provide additional protection for sites on privately owned land in Oregon, where state law does not prohibit the excavation or disturbance of archaeological sites (other than burials) with landowner permission.

In a chapter describing the role of the Forest Service in the Scenic Area, the Management Plan states that:

The Management Plan goal is to protect cultural resources from potential adverse effects. Site-specific inventory and analysis, consultation with Indian tribes, and design of mitigation measures are required to implement this goal. Expanded and strengthened law enforcement efforts will also be developed to reduce or minimize theft and vandalism of cultural resources (IV-19).

An annual monitoring program will also examine the "effectiveness of law enforcement efforts for preventing vandalism of cultural resource sites" (IV-19).

The passage of the Scenic Area Act, and the management plan developed to implement the Act, are the most recent attempts in the long history of the Columbia River Gorge to manage its disparate resources. The management plan also, for the first time, limits the nature and degree of development which may occur in this region, and is applicable over two states, six counties, numerous federal agencies, and private landowners. Preservation of cultural as well as 
natural, scenic, and recreation resources, is a high priority of this legislation. The Management Plan for the Scenic Area addresses the prevention and mitigation of the effects of development on cultural resources with stringent policies and guidelines. Vandalism, however, is treated as an issue in law enforcement. 


\section{CHAPTER V}

\section{METHODOLOGY}

This study is directed by the hypothesis that rock art sites within the Scenic Area which are easily located and which have been the focus of public awareness are expected to be the most severely vandalized. The methodology used to test this hypothesis involves a statistical test of association of the 15 sites in this study with a series of locational, descriptive, and managerial attributes involving issues of access, ownership, and public awareness of the sites.

Selection of the 15 rock art sites for study in this project was based on the concentration of rock art in Klickitat County, documented by McClure in a 1978 survey and compilation of rock art sites in the state of Washington. Forty-four rock art sites are located in the Scenic Area, and the majority of these occur a few miles upstream from The Dalles Dam in Klickitat County (Fig.9), an area McClure (1984) describes as having the highest concentration of rock art in the state. Because public awareness of the rock art is a variable thought to affect vandalism, the inclusion of sites which are well-known to the public is necessary in order to test the hypothesis. Some of the most renowned rock art in the Scenic Area occurs in sites located in Horsethief Lake State Park in Washington (Fig. $10)$, and these sites were included in this study.

The rock art located at the west end of Horsethief Lake State Park has 


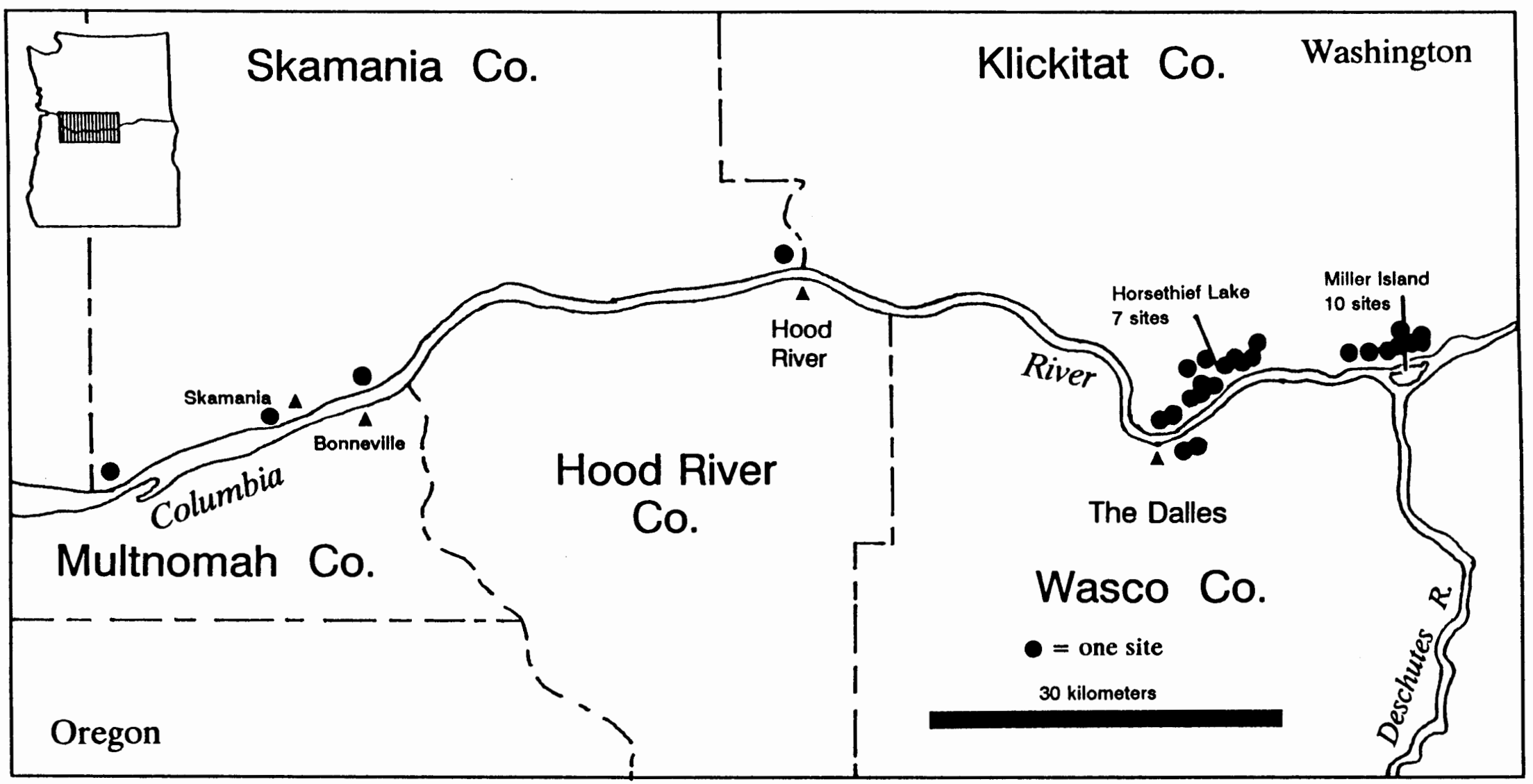

Figure 9. The 44 non-inundated rock art sites in the Columbia River Gorge National Scenic Area. Base map from Beckham et al. (1988). 


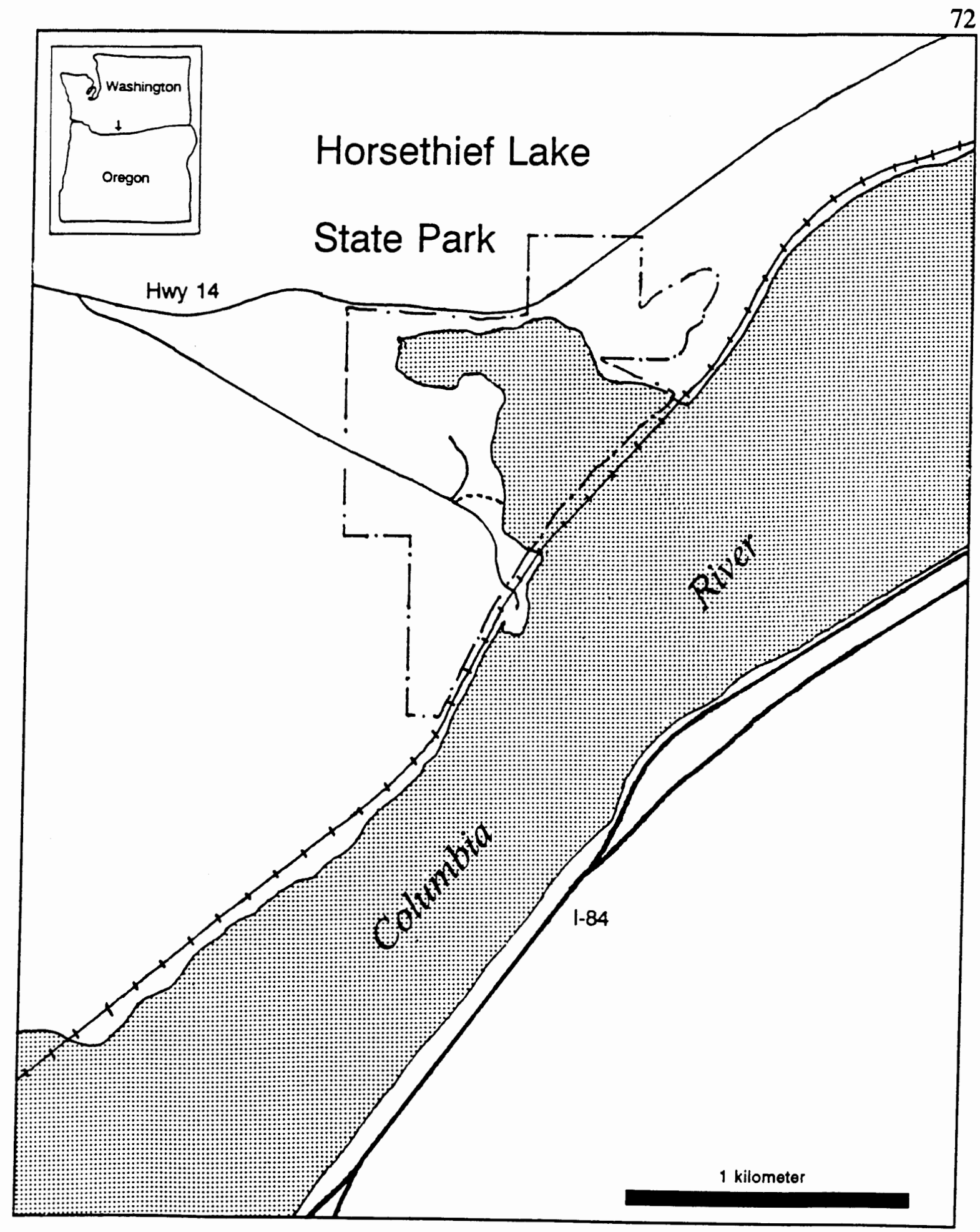

Figure 10. Horsethief Lake State Park, Washington. Base map from USGS 7.5 quads. 
been the focus of public attention for many years. Edward S. Curtis photographed some of the rock art in what is now the park, including the Tsagiglalal image (Fig.3), which was included in Volume 8 of his North American Indian series (cited in McClure 1984). Until the winter closure of the park in October 1992, no restrictions were placed on visitor access to the rock art. Although none of the other sites in this study have obtained the notoriety of the rock art at Horsethief Lake State Park, most of the remaining sites were selected for their ease of access in order to test the relationship between access and vandalism. Several sites which are difficult to locate were also included for comparison.

\section{DATA COLLECTION}

Data from this study were gathered from archival research and field investigations. The purpose of the archival research was to determine the number, type, location, and ownership of the recorded rock art sites within the Scenic Area. This was accomplished by acquiring the site records for all the recorded rock art sites in the area. The maintenance of archaeological site records is mandated by the National Historic Preservation Act of 1966, which requires states to prepare and implement state historic preservation plans. The State Historic Preservation Offices (SHPOs) of most states receive completed site inventory forms from archaeological consultants, individuals, universities, and other institutions. These forms vary in style, but most contain locational and other information related to each site. Site numbers are usually assigned to the 
recorded sites by the SHPO office upon receipt of the forms. The site numbering system used in many states, including Washington and Oregon, is adapted from the Smithsonian Institution River Basin Surveys Trinomial Site Designation System. This system utilizes the state's numerical position among the 50 states, followed by a county abbreviation, then a final number representing the site's numeration within the county. For example, the large concentration of rock art in Horsethief Lake State Park in Washington has a state site number of 45KL58: 45 representing the state of Washington, $\mathrm{KL}$ an abbreviation for Klickitat County, and 58 as the 58th site to be recorded in Klickitat County. These site numbers will be used in the tables used to illustrate the associations between the sites and the variables affecting vandalism.

Several state and federal agencies provided the site forms and other information pertaining to the recorded rock art sites of the Scenic Area. These sources indicate that 156 archaeological sites are recorded in the Scenic Area, of which 42 are non-inundated rock art sites. Two additional rock art sites were recorded in Klickitat County, Washington, by the author during the course of the field investigations for the present study, bringing the total number of recorded rock art sites to 44 .

Field work consisted of visiting and photographing 15 of the 44 sites (Fig. 11). Most of the sites were chosen for their ease of access, which was affected both by the issue of physical access and property rights. Although at least 10 of the 15 sites could be accessed fairly easily by boat from the Columbia River, all 


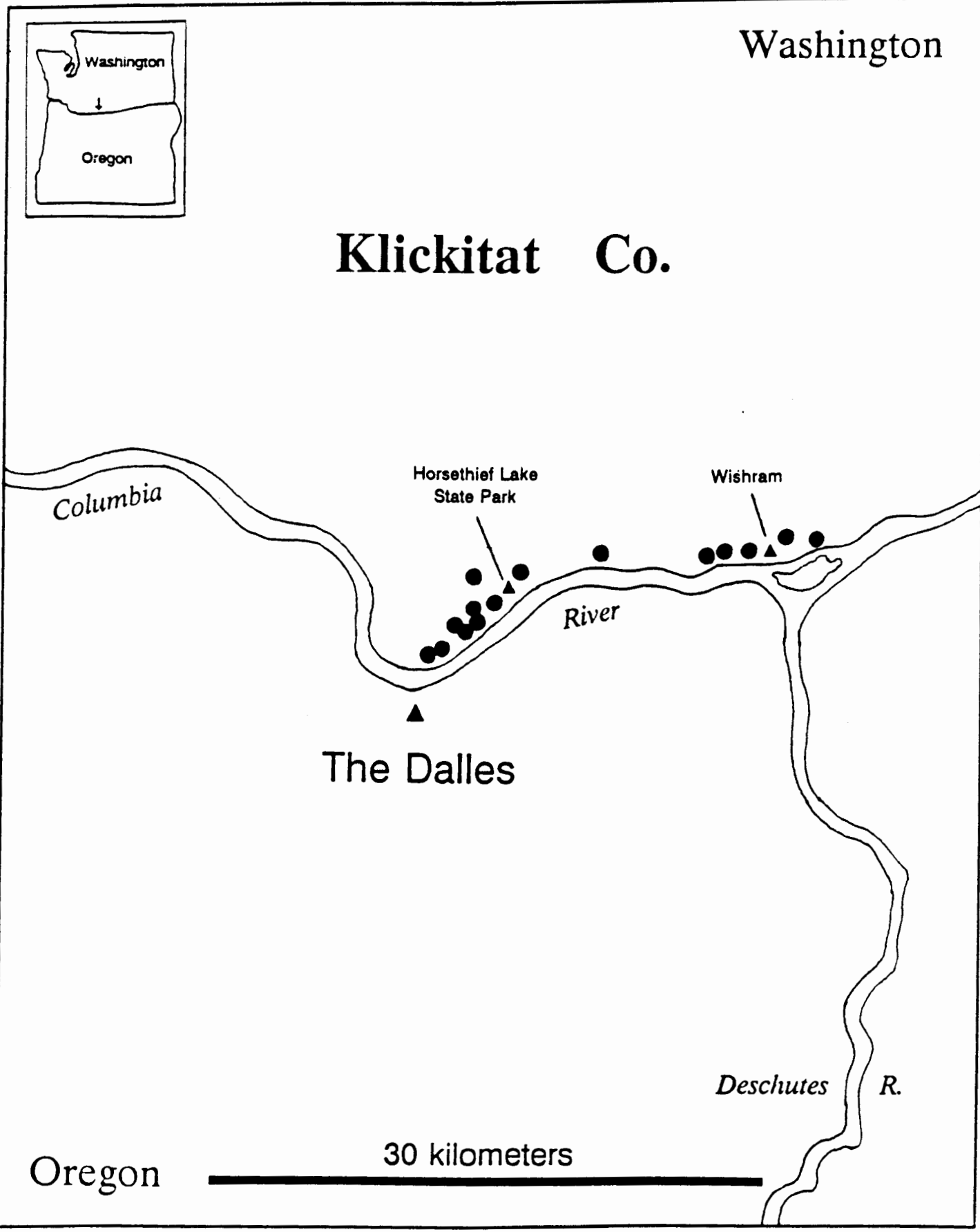

Figure 11. The 15 rock art sites selected for the study of vandalism to the rock art sites of the Columbia River Gorge National Scenic Area. Base map from Beckham et al. (1988). 
sites were found on foot with a 2.2 kilometer walk or less. Sites were located with the aid of the site forms and the use of USGS topographic maps. The approximate distance from the various means of access to the sites was obtained from these USGS maps, as were the distances to nearby communities, parking, boat launch facilities, and other variables.

The sites in Horsethief Lake State Park were accessed from footpaths, while the sites located ouside of the park bounderies were accessed from railroad tracks, gravel roads, and highways in Klickitat County. The sites were assessed for kind and degree of vandalism, as well as for signs of vandalism in the immediate vicinity, and means and ease of access. These variables (Table IV) were incorporated into a model to assess the relationship between access, public awareness of the rock art, and vandalism.

\section{DATA ANALYSIS}

The statistical analyses of the data in this study involved the use of Fisher's exact test of association, which analyzes the degree of association among categorical data, and a t-test used for the non-categorical data, such as distance. Fisher's exact test is a test of association similar to chi-squared tests, and involves the analysis of the number, or frequency, of subjects in various categories. The categorical data used in this study consist of the variables associated with vandalism, listed in Table IV, other than measurements of distance (which were analyzed with the t-test). Fisher's test is used to examine the null hypothesis that 
TABLE IV

\section{DESCRIPTIVE, LOCATIONAL, ACCESS, AND AWARENESS VARIBLES OF THE 15 ROCK ART SITES SELECTED FOR STUDY IN THE COLUMBIA RIVER GORGE NATIONAL SCENIC AREA}

\begin{tabular}{|c|c|c|}
\hline Variables & Numeric designation & Description \\
\hline Site ownership & $\begin{array}{l}1=\text { federal } \\
2=\text { private }\end{array}$ & $\begin{array}{l}\text { Sites on federal property are owned by the } \\
\text { U.S. Army Corps of Engineers. }\end{array}$ \\
\hline Site size & $\begin{array}{l}1=\text { small } \\
2=\text { medium } \\
3=\text { large }\end{array}$ & $\begin{array}{l}\text { Small sites are those which consist of one to } \\
\text { four separate rock art images. Medium sites } \\
\text { contain five to ten images, while large sites } \\
\text { have eleven or more images. }\end{array}$ \\
\hline Site type & $\begin{array}{l}1=\text { pictographs } \\
2=\text { petroglyphs } \\
3=\text { both }\end{array}$ & $\begin{array}{l}\text { Pictographs are images painted on stone. } \\
\text { Petroglyphs are images carved or etched into } \\
\text { stone. }\end{array}$ \\
\hline Primary means of access & $\begin{array}{l}1=\text { footpath } \\
2=\text { railroad tracks } \\
3=\text { gravel road } \\
4=\text { paved road } \\
5=\text { unpaved road } \\
6=\text { the Columbia River } \\
7=\text { a combination of means } \\
0=\text { none of the above }\end{array}$ & $\begin{array}{l}\text { These variables represent the easiest means of } \\
\text { access to the sites. "Primary" also indicates } \\
\text { the means used to access the sites for the } \\
\text { purposes of this study. }\end{array}$ \\
\hline
\end{tabular}


TABLE IV

DESCRIPTIVE, LOCATIONAL, ACCESS, AND AWARENESS VARIABLES

OF THE 15 ROCK ART SITES SELECTED FOR STUDY IN THE

COLUMBIA RIVER GORGE NATIONAL SCENIC AREA

(continued)

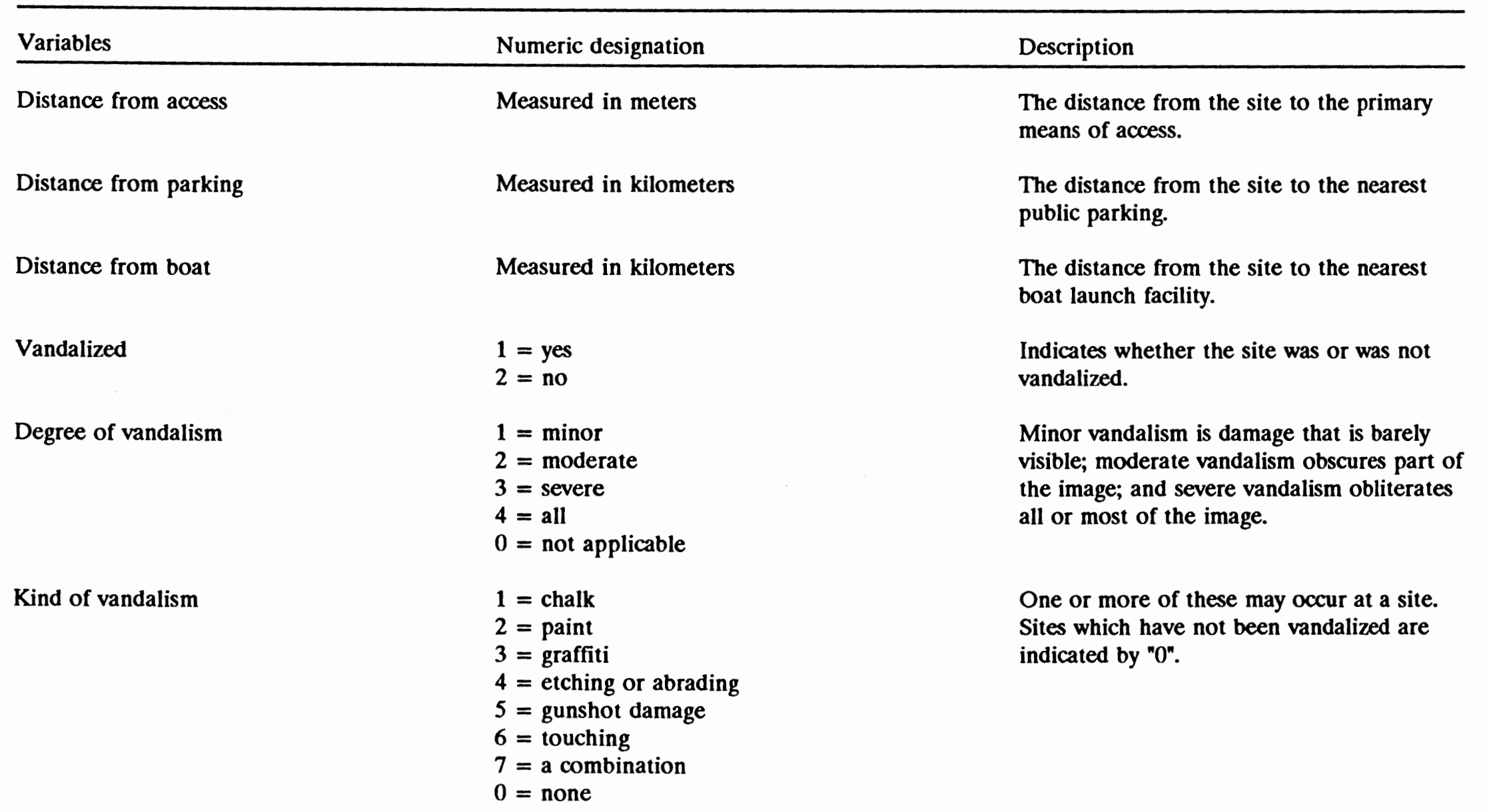


TABLE IV

DESCRIPTIVE, LOCATIONAL, ACCESS, AND AWARENESS VARIABLES

OF THE 15 ROCK ART SITES SELECTED FOR STUDY IN THE

COLUMBIA RIVER GORGE NATIONAL SCENIC AREA

(continued)

\begin{tabular}{lll}
\hline Variables & Numeric designation & Description \\
\hline Nature of vandalism & $\begin{array}{l}1=\text { inadvertant } \\
2=\text { deliberate } \\
3=\text { both } \\
0=\text { not applicable }\end{array}$ & $\begin{array}{l}\text { Inadvertant vandalism is defined as } \\
\text { unintentional damage to the rock art, and } \\
\text { commonly occurs from touching or using } \\
\text { chalk to outline an image for } \\
\text { photographing. }\end{array}$ \\
Distance to The Dalles & Measured in kilometers & $\begin{array}{l}\text { The distance from the site to the city of The } \\
\text { Dalles, Oregon. }\end{array}$ \\
Distance to The Dalles Dam & Measured in kilometers & $\begin{array}{l}\text { The distance from the site to The Dalles } \\
\text { Dam. }\end{array}$ \\
Distance to Wishram & Measured in kilometers & $\begin{array}{l}\text { The distance from the site to the town of } \\
\text { Wishram, Washington. }\end{array}$ \\
Distance to Horsethief Park & Measured in kilometers & $\begin{array}{l}\text { The distance from the site to Horsethief } \\
\text { Lake State Park, Washington. A zero } \\
\text { indicates that the site is within the park } \\
\text { boundaries. }\end{array}$
\end{tabular}


TABLE IV

DESCRIPTIVE, LOCATIONAL, ACCESS, AND AWARENESS VARIABLES

OF THE 15 ROCK ART SITES SELECTED FOR STUDY IN THE

COLUMBIA RIVER GORGE NATIONAL SCENIC AREA

(continued)

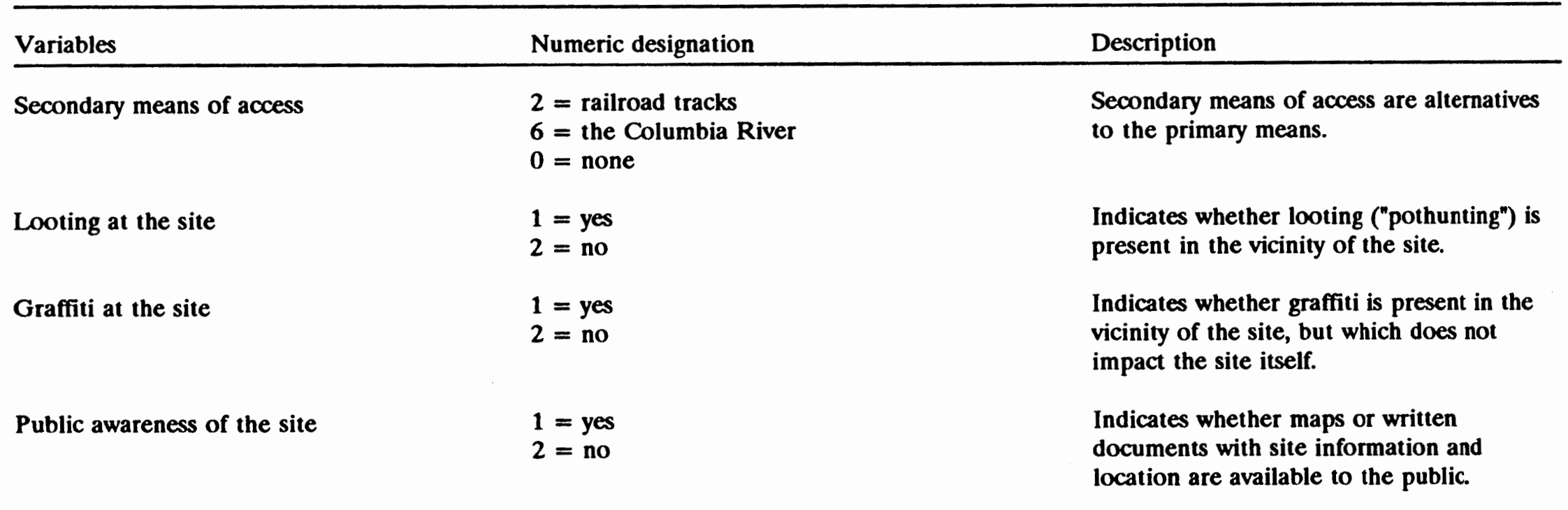


there is no association between vandalism and the categorical variables. This is accomplished by evaluating the observed frequencies of vandalized and unvandalized sites in categories affecting vandalism, and comparing this with the expected frequencies. Expected frequencies are those that would be observed, on the average, if the null hypothesis were true, that is, if vandalism and the factors affecting vandalism were unrelated. The null hypothesis is rejected if the observed frequencies deviate substantially from the expected frequencies. If the null hypothesis is rejected, an association exists between vandalism and the categorical variables which is not due to chance.

The t-test performed on the distance variables also involves the use of a null hypothesis, which in this study is that the distance (or proximity) of a rock art site to the nearest means of access, public parking, parks, and towns, is unrelated to the vandalism of that site. The null hypothesis is tested by comparing the mean distance from two groups of sites, vandalized and unvandalized, from variables such as access, roads, and towns. The null hypothesis is rejected if the difference between these two means is too large to have occured by chance.

\section{DATA LIMITATIONS}

One of the principal limitations imposed by the nature of this study is the restriction of information made available to the public concerning the location, nature, and extent of recorded archaeological sites. Washington state statute 42.17.300(1)(k), Section 304 of the National Historic Preservation Act, Section 
9(a) of the Archaeological Resources Protection Act, and Section 6(a)(1)(A) of the Scenic Area Act each prohibit the disclosure to the public of information which could lead to the location of archaeological sites. These regulations were imposed due to the risk of "... harm, theft, or destruction to resources or to the place where resources are located" (U.S. Department of the Interior 1988). Although permission was granted by the Washington State SHPO and Scenic Area officials to review site records, maps, and other documents for the purposes of this study, use of detailed maps and descriptions of the locations of the sites included in this study will be avoided to comply with relevant law and to prevent further access and vandalism.

Site accessibility was another limiting factor. One site, $45 \mathrm{KL} 224$, proved to be considerably more difficult to locate than indicated on the site form and map. It is not readily visible and is situated in one of the several small draws west of Horsethief Lake State Park which do not appear on the USGS maps due to the low height of their basalt cliffs. Another site is located on private property at the edge of a high bluff overlooking the Columbia River, and would not have been accessible without permission from the landowner to drive across her property from Washington State Highway 14. Other sites which also appeared to be easy to find from their position on the map could not be located, and were not included in this study.

The assessment of degree of damage inflicted from vandalism is an attempt to quantify what is essentially a subjective impression. The assessment is based on 
visual inspection only, and does not attempt to determine whether the rock art could or could not be repaired or restored.

Finally, the sample of 15 rock art sites, biased by accessibility from a small population of only 44 rock art sites in the Scenic Area, imposes limitations on the applicability of this model to all of the sites within the Scenic Area. The association analysis utilized to measure the relationship between vandalism, access, and public awareness can identify variables which are associated with the vandalism of the 15 sites. The presence of these variables may be indicators or predictors of site vandalism, but the small sample used in this study will not necessarily provide a predictive model for all sites in the Scenic Area or elsewhere. 


\section{CHAPTER VI}

\section{RESULTS AND DISCUSSION}

The results of the statistical analysis found six associations of variables which were statistically significant at the $5 \%$ level, and one slightly more tenuous association at the $10 \%$ level of significance. (These associations are summarized in Table V, while the sites and their relationship to all the variables appear in Appendix A, and the complete analysis performed on all variables appears in Appendix B.) Significant statistical associations were found between 1) vandalism and site size; 2) vandalism and public awareness; 3) the presence of graffiti in the vicinity of a site, and the size of the site; 4) the degree of vandalism and the presence of graffiti in the vicinity; 5) the nature of the vandalism and the presence of graffiti in the vicinity; 6) degree of vandalism and site size; and 7) vandalism and the primary means of access. This last association tested to a $10 \%$ level of significance, while the others tested at the $5 \%$ level. Six of the 15 sites in the study sample were found to be vandalized, and a chart of these sites and the characteristics associated with their vandalism appears in Table VI. Neither Fisher's exact test nor the t-test revealed any statistically significant associations related to the unvandalized sites.

The statistical association revealed by the analysis between vandalism and public awareness of the rock art sites supports the hypothesis of this thesis. Of 
TABLE V

STATISTICALLY SIGNIFICANT ASSOCIATIONS BETWEEN THE VARIABLES RELATED TO THE VANDALISM OF THE 15 ROCK ART SITES SELECTED FOR STUDY IN THE COLUMBIA RIVER GORGE NATIONAL SCENIC AREA

\section{Associated Variables}

Vandalism and site size.

Vandalism and public awareness of the sites.

The presence of graffiti in the vicinity of the site and site size.

Degree of vandalism and the presence of graffiti.

Nature of vandalism and the presence of graffiti.

Degree of vandalism and site size.

Vandalism and the primary means of access. (This association tested to a $10 \%$ level of significance. The other associations tested to a $5 \%$ level of significance.)

\section{Association}

More large sites were vandalized than would be expected if there were no relationship between vandalism and site size. Fewer small sites were vandalized than would be expected if there were no relationship between vandalism and site size.

More sites than expected were vandalized when the public was aware of those sites.

More large sites than expected had graffiti present in the vicinity.

More sites than expected with graffiti present in the vicinity had minor, moderate, and severe degrees of vandalism.

There were fewer sites than expected with graffiti present in the vicinity in which the vandalism at the site was inadvertent.

There were more large sites than expected with minor, moderate, and severe degrees of vandalism.

More sites than expected were vandalized when the primary means of access was a footpath. 
TABLE VI

THE SIX VANDALIZED ROCK ART SITES FROM THE 15 SELECTED FOR STUDY AND THE STATISTICALLY SIGNIFICANT VARIABLES AFFECTING VANDALISM

\begin{tabular}{|c|c|c|c|c|c|c|c|c|c|c|c|c|c|}
\hline site & large & medium & smail & $\begin{array}{l}\text { public } \\
\text { awareness }\end{array}$ & $\begin{array}{l}\text { graffiti } \\
\text { present }\end{array}$ & $\begin{array}{l}\text { inadvertent } \\
\text { vandalism }\end{array}$ & $\begin{array}{l}\text { delib. } \\
\text { vand. }\end{array}$ & both & $\begin{array}{l}\text { minor } \\
\text { vand. }\end{array}$ & $\begin{array}{l}\text { mod. } \\
\text { vand. }\end{array}$ & $\begin{array}{l}\text { severe } \\
\text { vand. }\end{array}$ & $\begin{array}{l}\text { all } \\
\text { vand. }\end{array}$ & $\begin{array}{l}\text { foot- } \\
\text { path }\end{array}$ \\
\hline $45 \mathrm{KL} 58$ & $\mathrm{X}$ & & & $\mathbf{X}$ & $\mathrm{X}$ & & & $\mathbf{X}$ & & & & $\mathrm{X}$ & $\mathbf{X}$ \\
\hline $45 \mathrm{KL} 78$ & & $\mathbf{X}$ & & $\mathbf{X}$ & & $\mathbf{X}$ & & & & $X$ & & & $\mathbf{X}$ \\
\hline $45 \mathrm{KL} 60$ & $\mathrm{X}$ & & & $\mathbf{X}$ & $\mathbf{X}$ & & $\mathbf{X}$ & & & & & $\mathbf{X}$ & \\
\hline 45KL96 & & $\mathbf{X}$ & & & & $\mathbf{X}$ & & & $\mathbf{X}$ & & & & \\
\hline
\end{tabular}


the six vandalized sites, three are the focus of public awareness as defined in this study: published maps or verbal instructions on how to reach the rock art 1) are, or 2) are not available. Two of these sites are located in Horsethief Lake State Park, and have been featured in newspaper articles (Moore 1992; Robertson 1990; Rubin 1989); U.S. Army Corps of Engineers pamphlets (1988); maps of the Scenic Area (Forest Service n.d.); journals (Dreyfuss 1983); and books about the rock art of the Columbia Plateau (Keyser 1992). These sources contain descriptions, photos, or maps that describe the sites, their locations, and in some cases give directions to the sites. A third site has been shown in photographs from which location can be discerned (Hill and Hill 1974), and is visible from a paved road nearby. None of the other three vandalized sites are the focus of public awareness.

The relationship between ease of access and vandalism is less clearly defined. Two of the six vandalized sites have footpaths as their primary means of access, and although this was more than would be expected if there were no relationship between primary means of access and site vandalism, the level of significance is just $10 \%$. These sites are relatively easy to access: the footpaths lead directly to the sites from the nearest parking, located 500 meters and 300 meters away. Though the analysis found no other statistically significant relationship between access-related variables, including distances, it did indicate that the mean distance from the primary means of access to vandalized sites is $\mathbf{3 7}$ meters, while the mean distance to unvandalized sites is 51 meters. The mean 
distance to the nearest parking from vandalized sites is just over 400 meters, while the mean distance from unvandalized sites is almost 700 meters. While these figures did not test to a $10 \%$ level of significance, they do indicate that the unvandalized sites are located further from both means of access and the nearest parking, which may make them less readily accessed. In contrast, four of the vandalized sites are located 10 meters or less from their primary means of access, and a fifth is located 50 meters from the means of access. These same sites are also located half a kilometer or less from the nearest parking. (The sixth, anomalous site is the elusive $45 \mathrm{KL} 224$, described in Chapter V. This site is located 150 meters from the railroad tracks which are its primary means of access, and 1.6 kilometers from the nearest parking.) Means of access and distance from access and parking may influence site vandalism by making the more distant sites less readily accessible, and therefore less prone to visitation and the threat of vandalism.

Two other factors were found to be statistically related to the vandalism of the rock art sites in this study: site size, and the presence of graffiti in the vicinity of the site. The statistical analysis found that more large sites were vandalized than expected, while fewer small sites were vandalized. Three of the six vandalized sites are large sites, two are medium in size, and only one is a small site. The nature of the large sites makes it difficult to interpret the association between site size and vandalism. It is possible that their increased visibility and areal extent makes them easier to locate, and that consequently more people 
discover them, increasing their chances for vandalism. However, the large sites in this study are also located in areas that make them more accessible to the public: one is in Horsethief Lake State Park, one is just outside of Wishram in an area utilized by off-the-road vehicles (Fig. 12), and one is visible from a paved road. The location of these sites may play as great a role in their vandalism as does their size.

The presence of graffiti in the vicinity of a site was associated with several variables, including site size, degree of vandalism, and the nature of the vandalism. The analysis found that more large sites than expected had graffiti present in the vicinity. Three of the five sites with graffiti present are large, vandalized sites. The other two sites with graffiti present are small, unvandalized sites. The large sites all had minor, moderate, and severe degrees of vandalism, including inadvertent and deliberate vandalism. Graffiti was not present at any sites with inadvertent vandalism alone. The graffiti at one of the small unvandalized sites is minimal, consisting of a carved name (Fig. 13). The graffiti at the other small site consists of a newly-carved, contemporary petroglyph, almost certainly non-Indian in origin (Fig. 14), and was initialed by its creator. This unique example of graffiti was the only one of its kind observed during the field work for this study, and there is no mention of other contemporary rock art in the literature of the Scenic Area. Both the recent petroglyph and the carved initials are situated away from the rock art images of the sites themselves, but near enough to be associated. These small unvandalized sites are not as easily located as most of the vandalized 


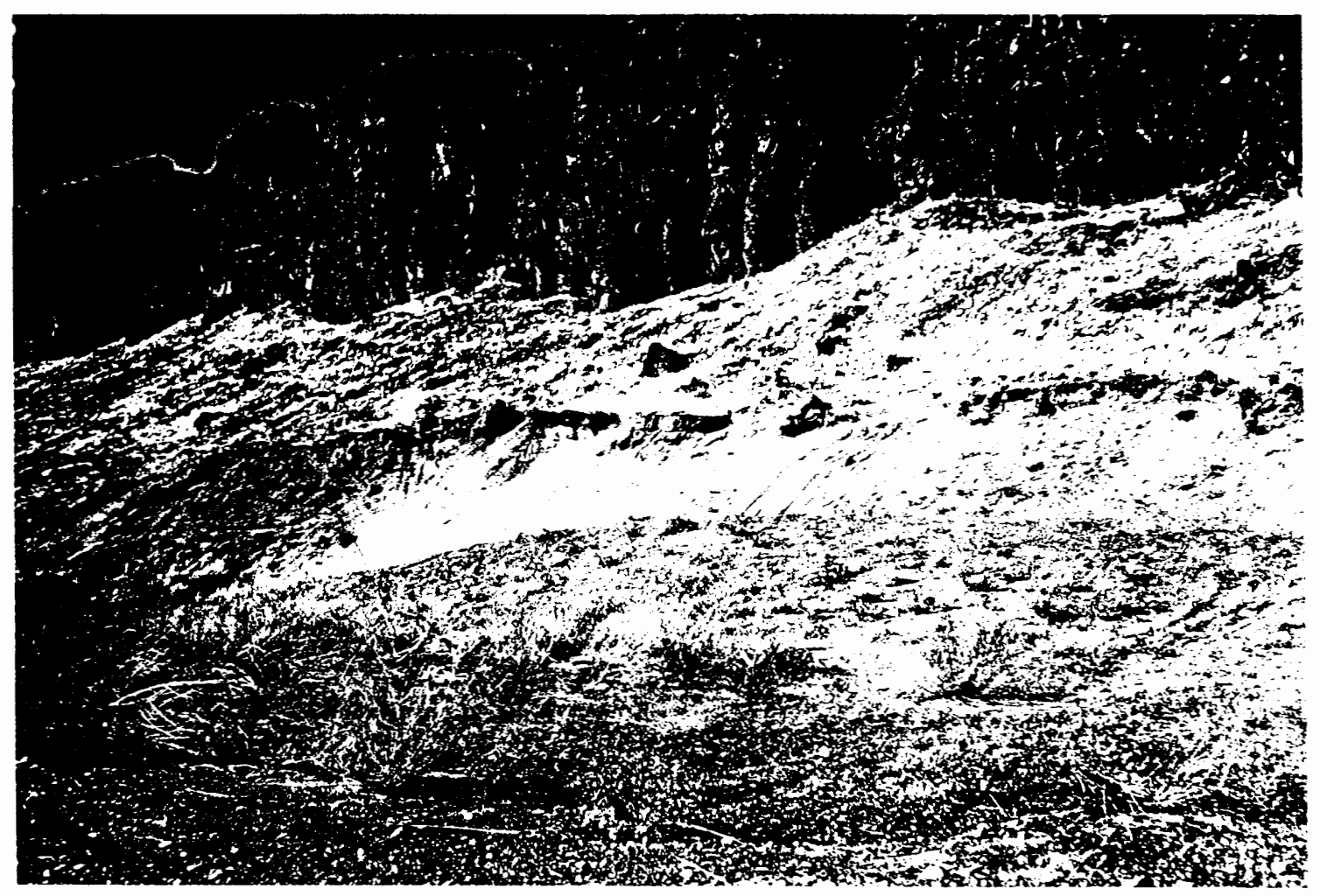

Figure 12. Off-road vehicles near a rock art site outside of Wishram, Washington. 


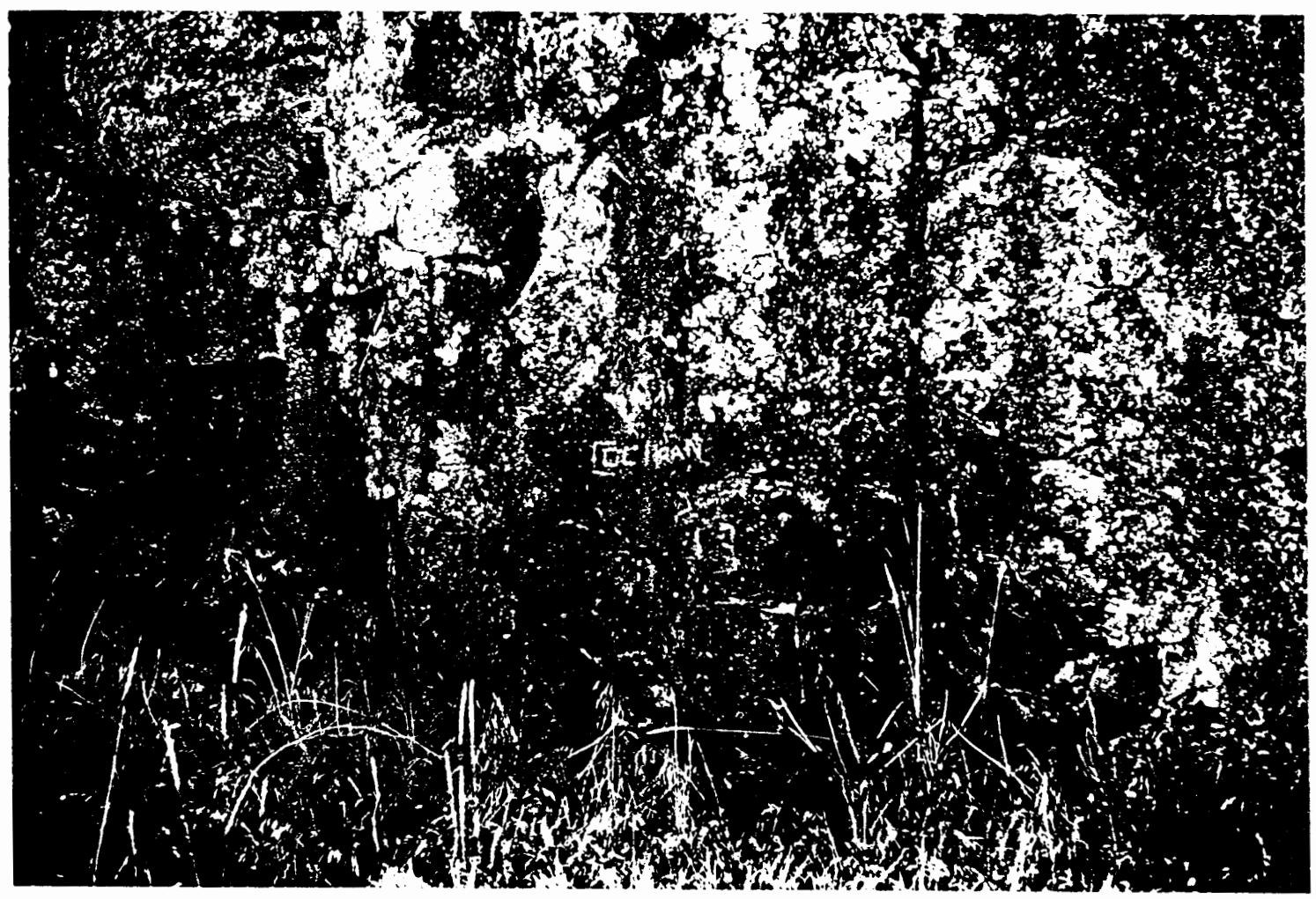

Figure 13. Graffiti situated near a rock art site in the Columbia River Gorge National Scenic Area. 


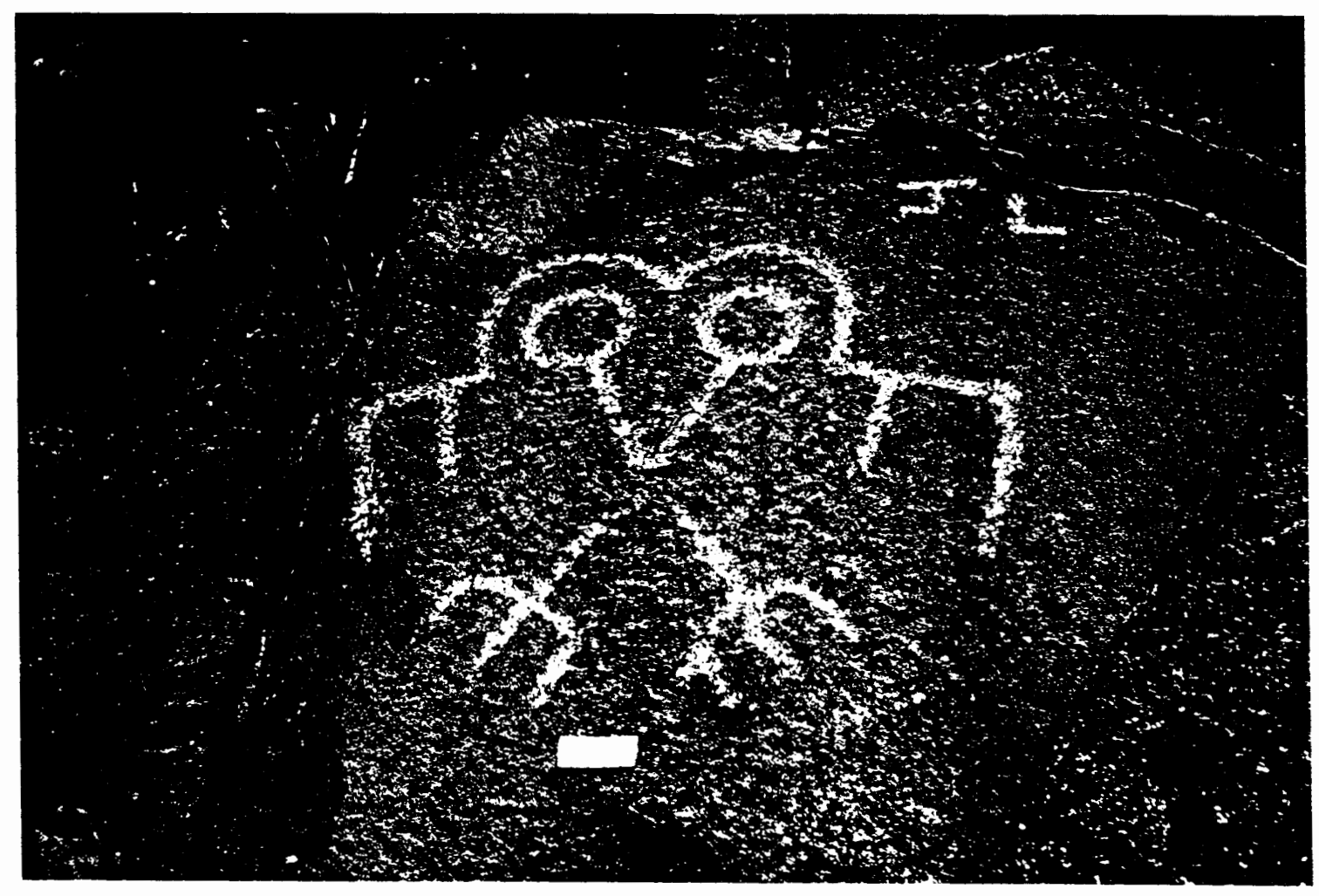

Figure 14. Graffiti in the form of a recent, non-Indian petroglyph, situated near a prehistoric rock art site in the Columbia River Gorge National Scenic Area. 
sites.

Unlike the small sites, the graffiti at the large, vandalized sites is situated within the boundaries of the sites, in proximity to rock art images, and adjacent to vandalized areas. There is also more of it, distributed over a larger area, and probably occurring over time since the presence of graffiti at rock art sites is thought to attract additional graffiti (Gale and Jacobs 1987; Higgins 1992; Silver 1989). This is evident at Horsethief Lake State Park, where graffiti dating to 1950 is present near several pictographs (Fig. 15), with additional undated graffiti appearing intermittently over the years throughout the site until the park was closed after a rash of prolific vandalism in the summer of 1992.

Although the results are not conclusive, the statistical analysis indicates that the hypothesis for this study is at least partially upheld by the association between site vandalism and public awareness of the site, and the ease of access to a site and site vandalism. Even though almost all the sites may be considered relatively accessible, the vandalized sites, for the most part, are among the easiest to access. Half were large-sized sites, which had graffiti present in their vicinity, and were the focus of public awareness. Interestingly, the presence of graffiti in the vicinity of a site, which was not considered to be a predictor of site vandalism, was found to be associated with the large sites, all of which are vandalized, and with deliberate rather than inadvertent vandalism. If graffiti in the vicinity of a site acts as an attractant which encourages additional graffiti, it might ultimately attract graffiti which directly impacts the site itself. Increased vandalism could therefore 


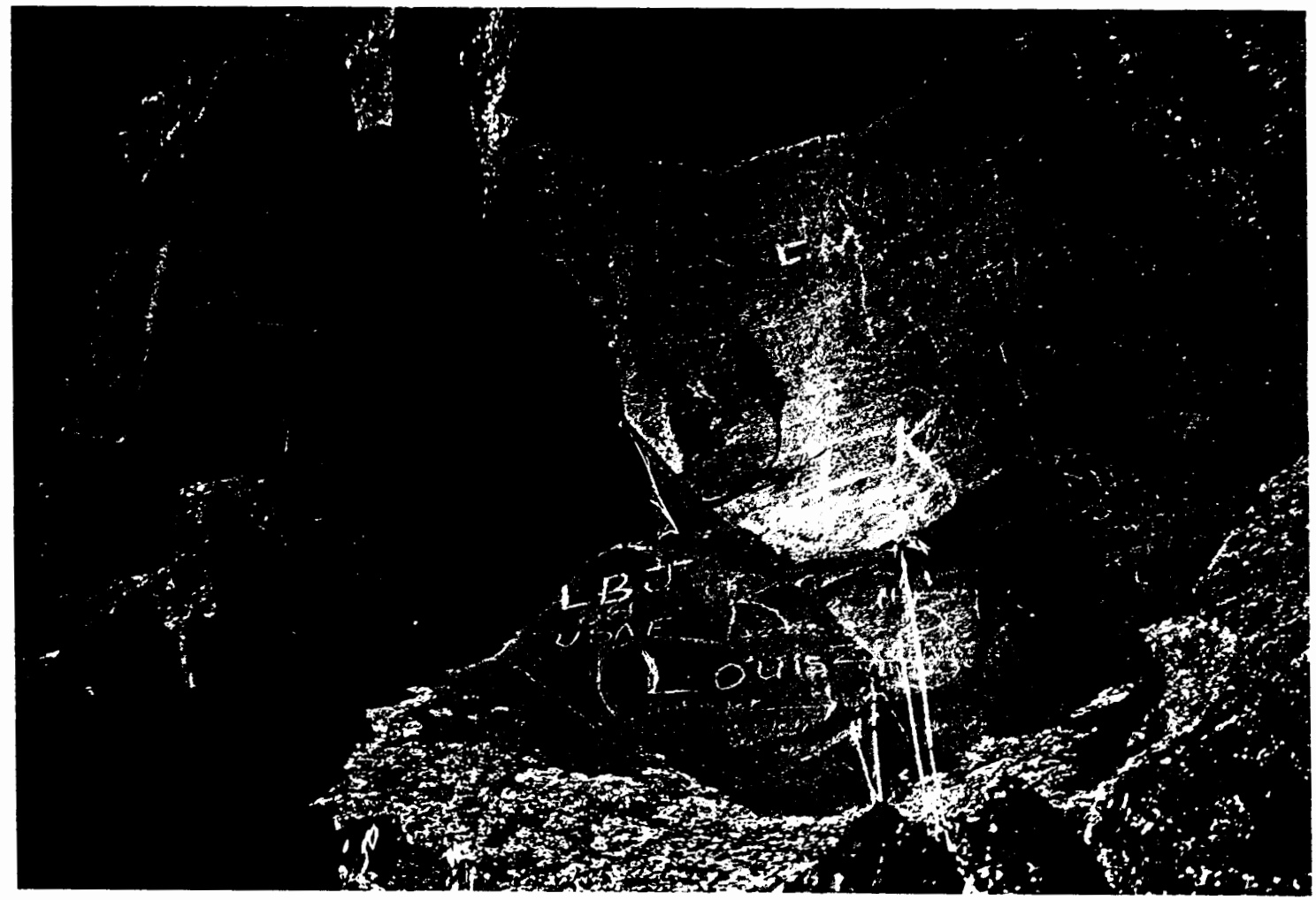

Figure 15. Graffiti at Horsethief Lake State Park, Washington. 
be the result of the presence of this type of graffiti.

Finally, four of the six vandalized sites occur near Wishram, and Horsethief Lake State Park, in official and unofficial recreation areas. The two sites in Horsethief Lake State Park are easily reached by a short walk on well-defined footpaths. One of these sites is impacted by rock climbers who have repeatedly touched and chalked the rock art as they ascend the cliffs where the pictographs are situated (Fig. 16). The second site in the park has been damaged by scratching, graffiti, touching, chalk, and paint. This site is the largest of the 15 in the present study, and the largest non-inundated rock art site in the Scenic Area. The Tsagiglalal image (Fig. 3 ) is found in this site, and attracts a number of visitors. Of the two sites near Wishram, one is located west of the town in an unofficial recreation area, where the use of off-the-road vehicles was observed (Fig. 11). On the east side of Wishram, the second site is visible a short distance from a paved road, and has been vandalized by paint and scratching (Fig. 17). Because these sites are located in places used for recreation, the rock art is exposed to higher numbers of people than the other sites in this study. This increases the chances for vandalism, particularly from the inadvertent damage caused by rock climbers.

The last two of the six vandalized sites are both small sites which were impacted by inadvertent vandalism, are not located near recreation areas or towns, and are relatively difficult to access. One of these sites is positioned on a bluff overlooking the Columbia River, and would be impossible to access without 


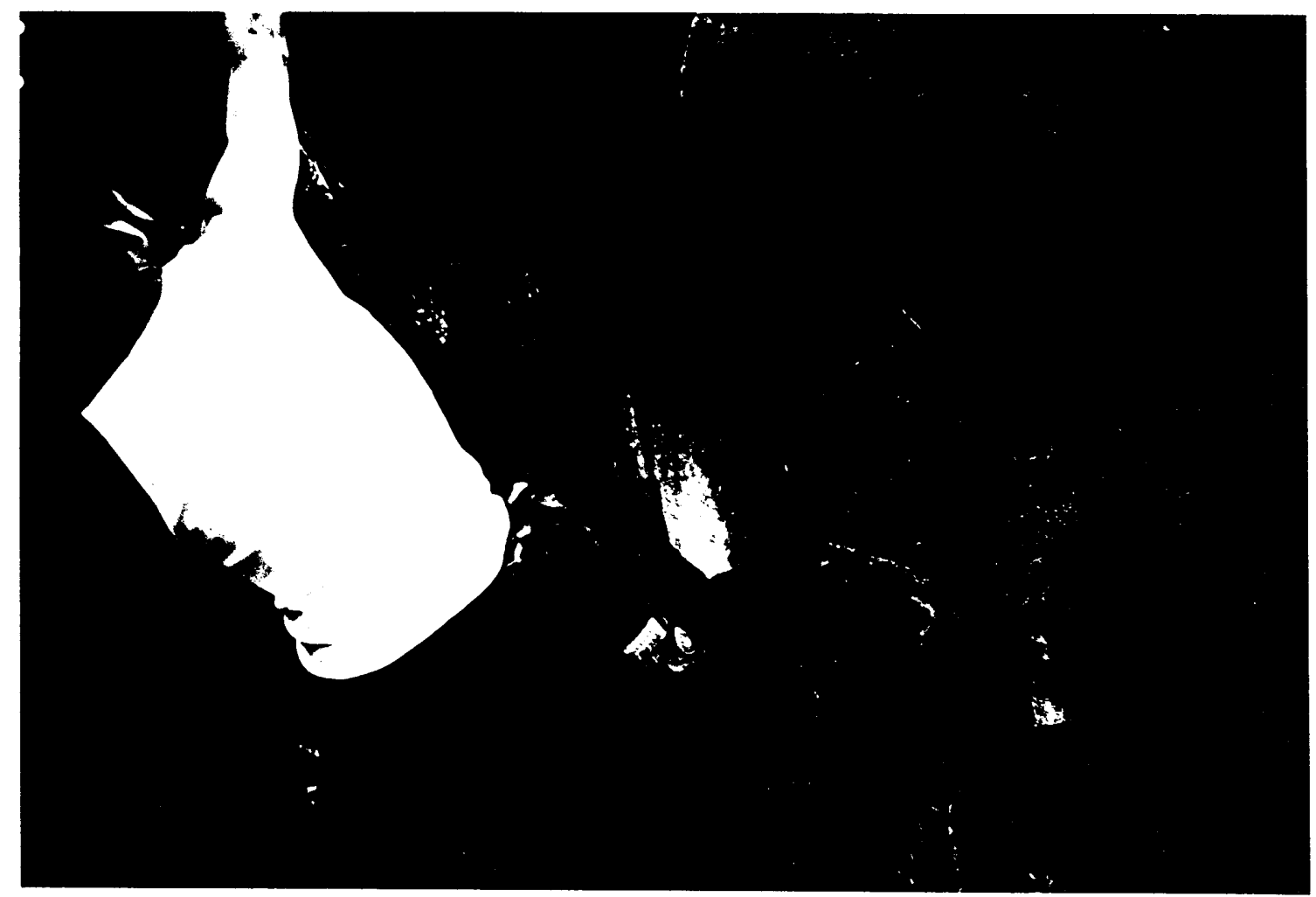

Figure 16. Rock-climber at a pictograph site in Horsethief Lake State Park, Washington. 


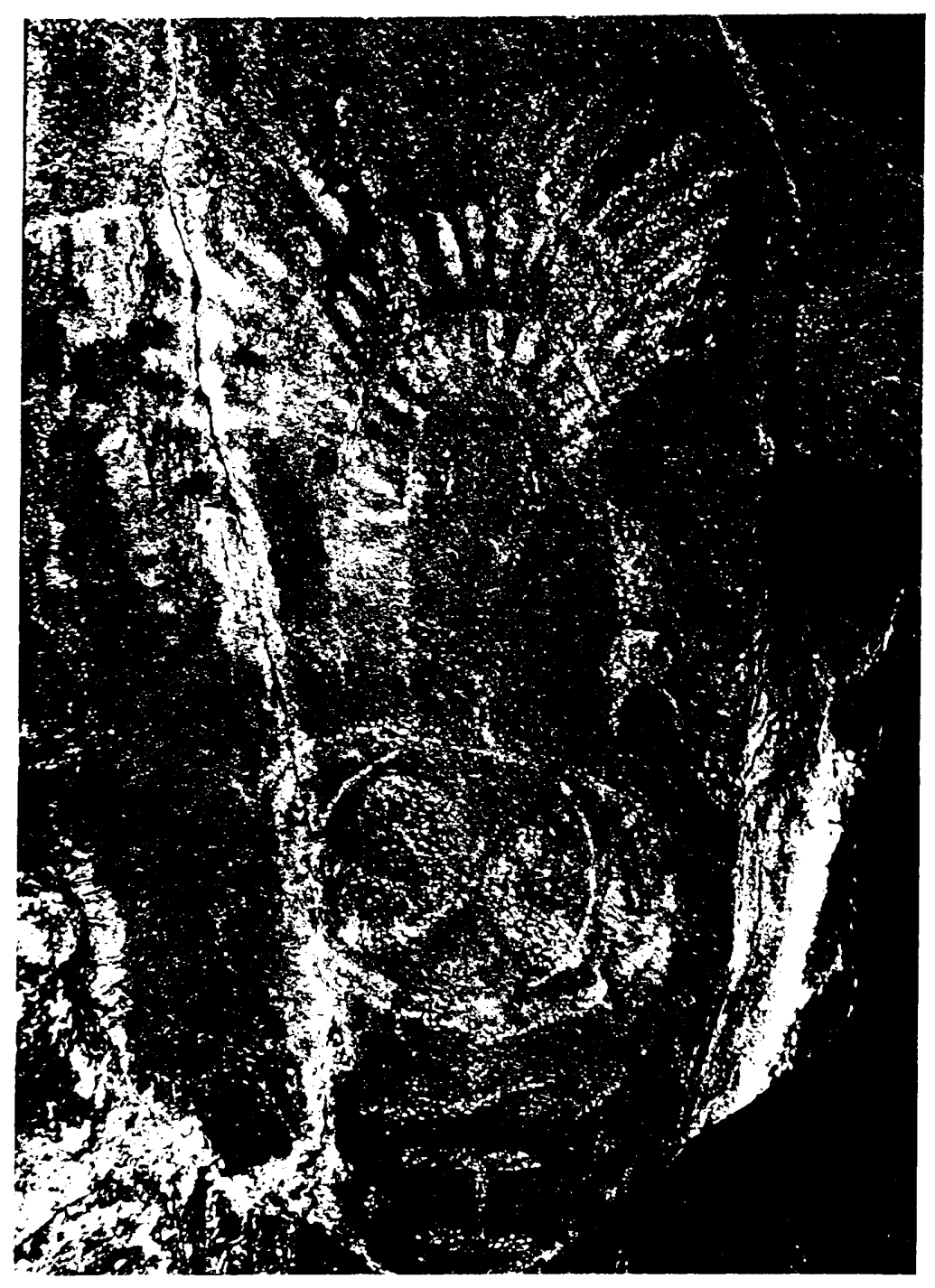

Figure 17. Vandalized pictographs east of Wishram, Washington. 
landowner permission. The vandalism at this site consists of a small amount of blue and red chalk applied over several petroglyphs. The last vandalized site is found in a remote area west of Horsethief Lake State Park, and is 45KL224. The nature of the damage at this site consists of thick brown paint coating a petroglyph of a vertically positioned fish. The lack of other forms of vandalism to the rock art at this site suggests that this is inadvertent vandalism, possibly the result of an attempt to render the image more distinct for photographs. It is not clear why this image, which is so difficult to access, and which is located on private land, should be vandalized. Perhaps, because images of fish are uncommon among the rock art of the Scenic Area, this site is known by word-of-mouth for its rarity, and is consequently sought out by those with an interest in the rock art (and perhaps the prehistory) of the area.

The relationship between access, site size, location, and public awareness corresponds to the results of Williams' research in 1978. His survey of state and federal resource managers indicated that access to and awareness of archaeological sites, particularly rock art, was considered to be related to site vandalism, as were increased tourism and visitation of recreation areas containing archaeological sites, and the knowledge and awareness of the sites by people living in the vicinity. Rock art was especially vulnerable when located in areas of frequent visitor use and when the sites were visible and had evidence of previous vandalism.

Awareness appears to be the factor most directly associated with site 
vandalism in the present study, according to the statistical analysis. However, less quantifiable types of awareness than those used in the analysis exist in the form of books, newspaper articles, and tourist information. These sources do not directly provide access information, but may contain drawings and photographs of the pictographs and petroglyphs of both the Scenic Area and the Pacific Northwest in general. Books and other public documents which describe or illustrate the rock art of the Scenic Area but which do not incorporate specific locational information include Loring and Loring (1982); Woodward (1982); Hill and Hill (1974); Strong (1959); McClure (1984 and 1978); the Management Plan for the Scenic Area (1992); a tourist's guide to California and the West Coast (Dunford 1989); and a book of photos and essays emphasizing the role of Native Americans in the Columbia River Gorge (Williams 1980). These sources include photos, drawings, and limited discussions of the nature and presence of the rock art of the Scenic Area. Illustrated publications such as these foster an awareness of the rock art of the Scenic Area, and may encourage readers to discover the locations of the sites in order to visit them.

Awareness of the rock art of the Columbia River Gorge National Scenic Area is also promoted with the increasing proliferation of t-shirts, jewelry, and gift items utilizing specific rock art images from the Gorge, from both inundated and non-inundated sites. Tsagiglalal is perhaps the most famous of the non-inundated rock art images from the Scenic Area. From the photographs by Edward Curtis 
at the turn of the century ${ }^{1}$ to the present it has been the focus of a considerable amount of attention. Most recently it has appeared on t-shirts, Bureau of Land Management (BLM) posters, and jewelry. Tsagiglalal has even been the center of a legal controversy after Skamania County, Washington, copywrited an artist's rendition of the Tsagiglalal image in 1989. This artist's image is used by the county to promote its Columbia Gorge Interpretive Center, and was copywrited and later made a trademark. In order to protect this trademark, Skamania County threatened to take legal action against the use of Tsagiglalal images by The Gorge Commission, the Bureau of Land Management, and designers of tshirts (Rubin 1989). At issue was the use of Tsagiglalal as a trademark: while photographs or other versions of the petroglyph are part of the public domain, use of any Tsagiglalal image with a company name or logo is prohibited by Skamania County's trademark. No further publicity ensued after 1989, and the county still uses the trademark image today. This incident illustrates the popularity of Tsagiglalal, and helps explain why this and the other rock art images of the Scenic Area are sought out by the public.

Rock art awareness in the Scenic Area is also promoted by the display of petroglyphs salvaged from Petroglyph Canyon during construction of The Dalles Dam. These are on display at the dam itself (Fig. 18), while additional salvaged rock art is on display at the Maryhill Museum in Klickitat County, Washington. Displays of this type also promote an interest in the rock art and

\footnotetext{
${ }^{1}$ According to Dreyfuss (1983), the early photos of Tsagiglalal show bullet holes which are still visible today.
} 


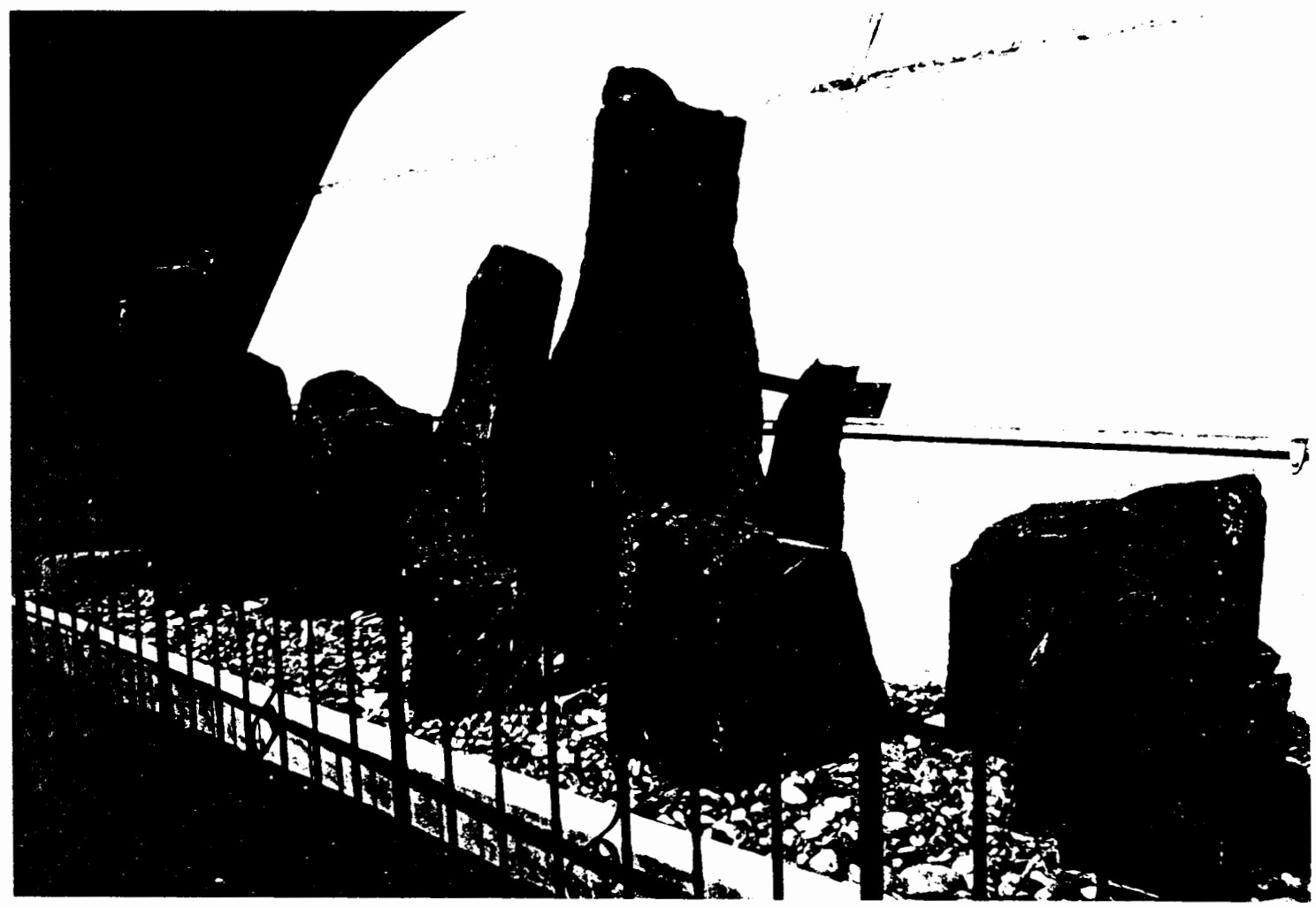

Figure 18. Petroglyph panels salvaged during the construction of The Dalles Dam. The petroglyphs are placed at the wall of the dam. 
prehistory of the area, particularly in the context of a tourist attraction.

\section{MANAGEMENT AND POLICY IMPLICATIONS}

Management of cultural resources often is centered almost exclusively around proposed developments and land uses which would have an adverse effect on archaeological and historical sites. Vandalism, on the other hand, is seen as a law-enforcement issue rather than a resource management issue. Prohibitions against disturbance, removal, or vandalism of archaeological sites are codified in both state and federal laws, yet provisions which address these forms of site destruction may not be included in resource management plans. However, in recent years, as vandalism increases and more studies are completed which examine the nature of vandalism, a growing number of land managers are addressing the vandalism problem. Literature on management techniques to prevent the vandalism of parks, recreation areas, and archaeological sites is widely available (for example, Gramann et al. 1992; Higgins 1992; Pilles 1989; and Sullivan n.d.).

In the Scenic Area, as elsewhere, one of the issues involved with preventing vandalism to archaeological sites is the public awareness of the existence and location of the sites. As stated earlier, Williams (1978) found that public knowledge of archaeological sites was one of the key factors which put these sites at higher risk of vandalism. This risk factor was enhanced when the sites showed signs of previous vandalism and had a high level of visitor use. At least one site in 
Horsethief Lake State Park has been well-known to the general public for many years, and has also been vandalized repeatedly over the years. Some of the authors who have written about this site caution the reader about the fragility of the rock art, or instruct visitors not to touch or otherwise disturb the site (Dreyfuss 1983; Keyser 1992; U.S. Army Corps of Engineers 1988). Other sources of information about the park and the rock art limit their discussion to pictures, photos, and descriptions (USDA Forest Service 1988; Robertson 1990).

While the literature described above can be found in bookstores, Forest Service offices, and at The Dalles Dam visitor center, no information about the rock art at Horsethief Lake State Park has been available at the park itself. Until the closing of the site to the public in October 1992, the site has been unmarked and unsigned except for general warnings about archaeological resources in the area (Fig. 19). No signs or informational literature has been provided about the rock art, and the path to the site has not been not identified as such. Although the park ranger would give tours of the rock art and provide information concerning the age, history, and irreplaceable nature of the site whenever possible, visitors often wandered unescorted through the area. Since the closure of the site, unrestricted public access has been prohibited. The rock art is now accessible only with prior permission and with an escort by the park ranger, in an attempt to curtail the ongoing vandalism. This arrangement will stay in effect until the completion of a management plan for the park by the archaeologist for the Warm Spring Indians. 


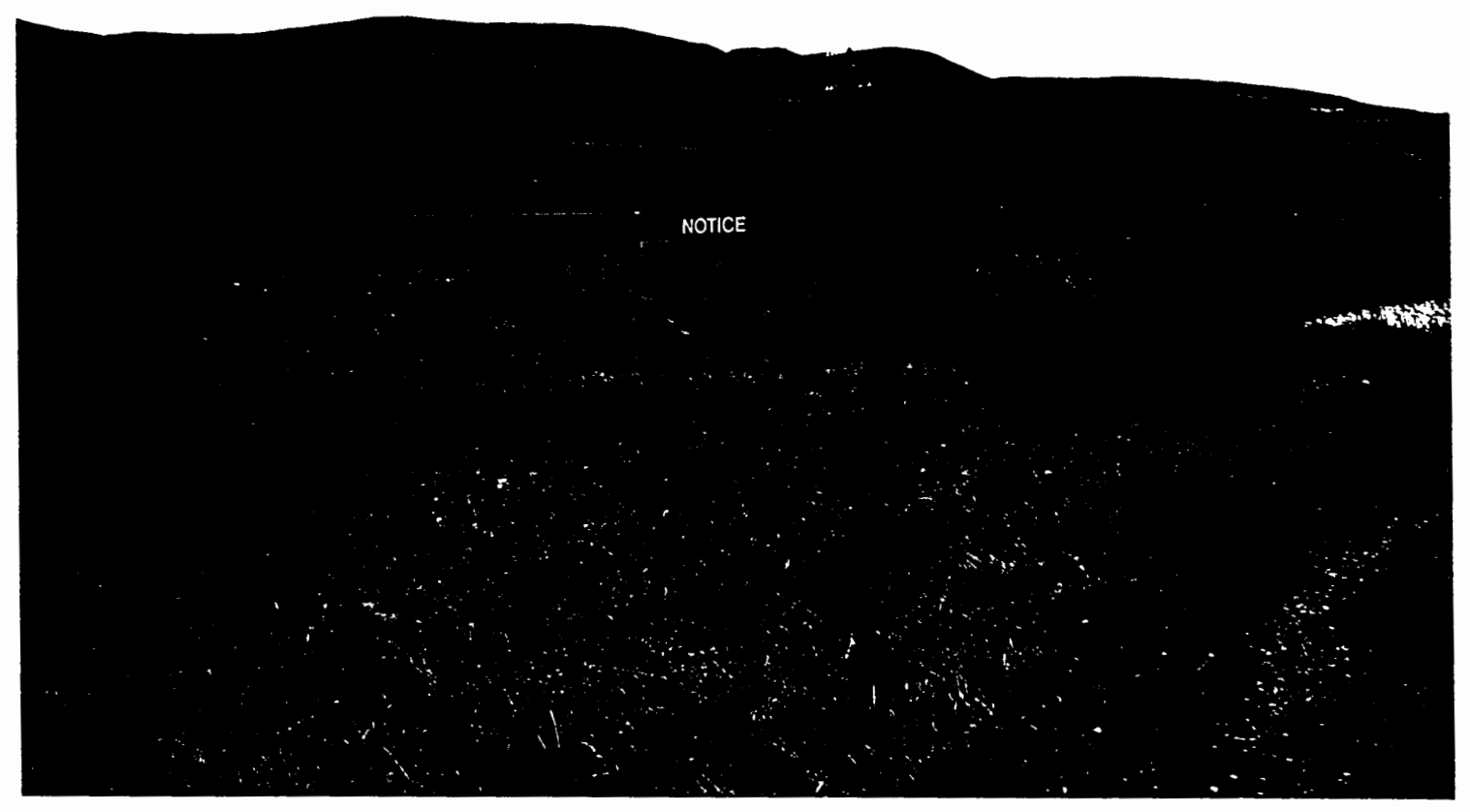

Figure 19. Sign at Horsethief Lake State Park, Washington, which cautions against the removal or disturbance of artifacts. 
Prevention of the kind of vandalism which occurred at Horsethief Lake State Park at other sites in the Scenic Area is complicated by site ownership. The site at Horsethief Lake is on public land owned by the Corps and administered by Washington State Parks, which leases the land from the Corps. Rock art sites on privately owned land are even more difficult to manage. These sites are protected by the same federal laws that protect sites on public lands, but have no park rangers or other land managers to oversee them. Discrepancies between state statutes leaves sites on private lands in Oregon outside of the Scenic Area with less protection from looting and vandalism than sites on private lands in Washington. Unlike publicly-owned sites, landowner permission must be obtained in order to access and assess the condition of a site on private property. This often occurs only if the landowner requests it, usually if trespassers were witnessed at the site, or if evidence of looting is present and the owner wants to attempt to prosecute.

Education of landowners and the public in general about cultural resources, their history, meaning, and importance to Native Americans, is one of the longterm solutions to looting and vandalism that is most frequently cited in the literature (Gramann et al. 1992; Higgins 1992; Pilles 1989). This is especially important in order to counteract the effects of looting and artifact hunting in areas such as the American Southwest and the Columbia River Gorge, where these activities have been popular, for fun and for profit, for decades. Some of the educational approaches successfully carried out by the Forest Service in the 
Southwest include lectures and tours of sites by archaeologists, active participation by the Forest Service in state Archaeology Week programs, television and radio announcements, cooperation with local amateur archaeology groups, and an archaeological summer camp for children (Pilles 1989). The emphasis in such efforts is to increase public awareness of the non-renewable nature of archaeological sites (including rock art), and to explain and interpret the cultural context and significance of the sites in order to promote an understanding and interest in the sites beyond their attractive (and often valuable) artifacts.

Gramann et al. (1992) support educational efforts aimed at reducing or eliminating destructive behaviors. The authors distinguish between direct and indirect management techniques to control visitor behavior in outdoor settings (including natural and cultural resources). Direct management approaches are those which involve law enforcement efforts, such as limiting access to a site or arresting vandals and pothunters. Indirect management is aimed at promoting what is termed "pro-social behavior" which is "not motivated by the expectation of a material reward for helping, or the threat of probable punishment for not helping" (255). This approach is especially effective when destructive behavior "is the result of ignorance of rules or lack of awareness of the negative effects of certain behaviors on resources" (258).

Pilles (1989) believes that strong law enforcement is of equal importance with educational efforts. Enforcement should target "the hard-core pothunter and vandal" (31) whose motives are malicious or profit-driven, rather than the casual 
weekend collector. Blackburn (1992) also advocates the role of law enforcement in conjunction with education and, like Pilles, sees a need for a focus on the apprehension of "high-level dealers and buyers" of artifacts (240). In short, education and involvement in the management and caretaking of archaeological and other outdoor recreational sites are considered to be the most effective means for protecting these resources from inadvertent vandalism and recreational artifact collecting, while increasing law enforcement efforts, including more arrests, convictions, and stiffer penalties, are considered to be the most effective means to protect the resources from professional artifact thieves and malicious vandals.

Of the sources cited above, only Pilles (1989) mentions the involvement of Native Americans in the cultural resource planning and management process. Australian journals typically stress the interaction and consultation with Aboriginal clans which takes place during all phases of management planning and implementation of rock art protection strategies in that country (Gillespie 1983; Sullivan 1984). The provisions of the National Historic Preservation Act (NHPA) require that Indian tribal governments be consulted in management planning which will affect cultural resources. However, the authors cited above do not mention that cultural resource managers must consult Native Americans, nor (with the exception of Pilles) do they cite any examples of Native American involvement in their articles. In the Scenic Area, both the Management Plan for the Scenic Area and NHPA require the involvement of tribal governments in the cultural resource management process. 
Law enforcement and education clearly would be useful approaches in the management of the rock art of the Scenic Area. Aside from Horsethief Park, the introduction of educational efforts would be most effective with the salvaged rock art at The Dalles Dam. The petroglyphs at The Dalles Dam were removed from Petroglyph Canyon (Fig. 4) in the late 1950s by the Corps prior to the flooding of the canyon by the creation of Lake Celilo. The petroglyphs are located in a strip of gravel abutting the wall of the dam (Fig. 18), and are approached via a train which connects the visitor's center on the Oregon shore with the dam itself. During a visit to the dam in 1991, the author found no mention of these petroglyphs at the visitor center or on the train ride, which includes a tour guide who provides information about the dam and the area seen from the train. No signs or literature are available at the dam or at the visitor's center which explain the presence of the rock art other than a brochure about the dam complex, which mentions that "Indian petroglyphs" can be found at the dam, and indicates their location on a map. Interestingly, it makes no further mention of the salvaged rock art, but does describe the Tsagiglalal site at Horsethief Lake State Park and urges visitors to the park not to vandalize the rock art there. The petroglyphs at The Dalles Dam are displayed in an area which offers limited protection from the elements, and are being impacted by the numerous pigeons which roost overhead (Fig. 20), as well as by touching from visitors. Since The Dalles Dam receives over one million visitors a year, the Corp could be informing a significant number of people about the cultural context of the petroglyphs, their history, the salvage 


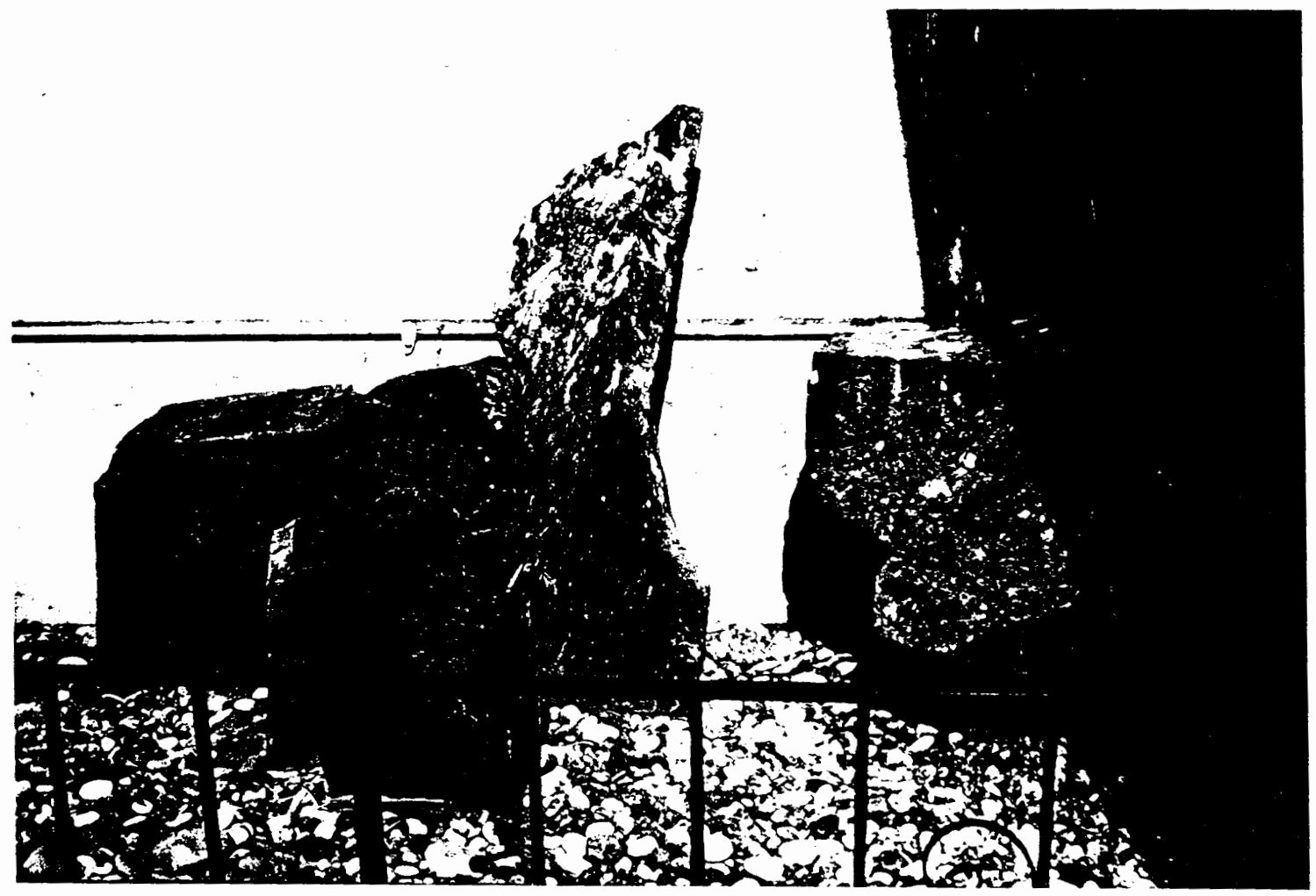

Figure 20. The effects of pigeons on the petroglyph panels at The Dalles Dam in the Columbia River Gorge National Scenic Area. 
efforts involved to save them from inundation, as well as providing information about the Indians who created them, the value of the rock art to the peoples of the Scenic Area today, and the about the importance of preserving the remaining cultural resources of the region.

Similar opportunities for public education exist at other popular tourist destinations in the Scenic Area. Multnomah Falls, the Bonneville Dam, and state parks could all incorporate displays and written information, such as brochures, which could inform visitors not only about the natural history of the area, but also of the cultural history. (A summary of management suggestions applicable to each land management agency in the Scenic Area appears in Table VII).

In the realm of law enforcement, increased patrols, arrests, and convictions of vandals and looters would certainly be desirable. However, this goal is complicated not only by lack of funding, but by the private ownership of the sites themselves. In order for law-enforcement patrols to be effective, they would need to cover a large amount of ground on a regular basis, and with the permission of the individual landowners. Arrests and convictions also depend on landowner willingness to file charges against perpetrators. Educational efforts concerning cultural resource protection and the law, aimed specifically at landowners, could help augment law enforcement efforts.

One of the management functions of the Forest Service in the Scenic Area is to monitor the natural and cultural resources of the region. The rock art sites of the Scenic Area, which are especially vulnerable to vandalism, should be 
monitored on a regular basis. Volunteer groups such as the Sierra Club, amateur archaeology associations, and interested Native Americans could be involved in the monitoring processes with training by the Forest Service. In the Cococino National Forest in Arizona, the Sierra Club helped to map and record various rock art sites, and have assisted in the removal of graffiti at other sites (Pilles 1989).

Finally, recording of the rock art sites is highly recommended, and could be accomplished by volunteers. Recording efforts would include mapping and other locational information, as well as drawings and photographs of the art itself. The susceptibility of rock art to natural and human-induced damage and destruction is such that every effort should be made to preserve a record of these sites. 
archaeology associations, and interested Native Americans could be involved in the monitoring processes with training by the Forest Service. In the Cococino National Forest in Arizona, the Sierra Club helped to map and record various rock art sites, and have assisted in the removal of graffiti at other sites (Pilles 1989).

Finally, recording of the rock art sites is highly recommended, and could be accomplished by volunteers. Recording efforts would include mapping and other locational information, as well as drawings and photographs of the art itself. The susceptibility of rock art to natural and human-induced damage and destruction is such that every effort should be made to preserve a record of these sites. 


\section{CHAPTER VII}

\section{CONCLUSIONS}

The results of the analysis of variables thought to affect site vandalism in the Columbia River Gorge National Scenic Area suggest that the vandalism to rock art sites appears to be affiliated less with locational factors than with other variables such as site size and public awareness of the sites. This may be due at least in part to the fact that almost all 15 sites are relatively easy to access, in that most are located less than two kilometers from the nearest parking, and less than 150 meters from their means of access. The proximity of the sites to urban and recreation areas was also less of a factor in site vandalism than anticipated. Instead, the variables which appear to be most directly associated with vandalism are the size of the site, the presence of graffiti in the vicinity of the site, and public awareness of the site. Further study with a larger sample, including most or all of the 44 rock art sites in the Scenic Area, might clarify these findings. Although the applicability of this study to the Scenic Area as a whole is indeterminate, large sites, and sites which are the focus of public attention, are likely to be at increased risk of vandalism.

The strong association between public awareness of rock art sites and vandalism suggests that prevention of future vandalism hinges on law enforcement and education. Cultural resource management literature supports the use of law 
enforcement as the appropriate method for reducing acts of deliberate vandalism such as graffiti applied over an image, or the attempt to destroy rock art images by etching and abrading. Educational efforts would address acts of inadvertent vandalism based on lack of knowledge of the effects of potentially destructive behaviors, including chalking an image to highlight it for photographs, creating graffiti in the vicinity of a site, or simply touching the rock art.

Efforts to curb vandalism to the rock art sites of the Scenic Area are especially important as the tourism industry expands and becomes more of an economic force in the region. The study of tourism trends conducted by Morse and Anderson in 1988 indicates that tourism in the Gorge was increasing steadily even before its designation as a National Scenic Area, and the study anticipates further growth in the future. The increase in visitors to the parks and recreation areas of the region will lead to increased pressure on the rock art sites such as those in Horsethief Lake State Park, and increased chances for vandalism. Sites which are the focus of public awareness and which are frequently visited are especially vulnerable, according to Williams (1979). Sites with graffiti are also at risk since graffiti at a site tends to encourage the creation of additional graffiti. Other forms of destructive behavior will also proliferate if not curbed, as one cultural resource manager in the Southwest has noted: "We have learned that vandalism, unchecked, leads to more vandalism" (Pilles 1989, 34).

The rock art of the Columbia River Gorge National Scenic Area represents a portion of the history and culture which existed in the region for many 
thousands of years. This history is still "more air than fabric" (Knudson 1989, 72) due to the loss and disturbance of archaeological sites from natural causes, such as erosion, and from human activities, such as the flooding which followed the construction of The Dalles Dam, and ongoing processes such as vandalism. The rock art of the Scenic Area is a reflection of the interactions between people from coastal areas who migrated up the Columbia to The Dalles area, and people from the Columbia Plateau. Without the preservation and interpretation of these sites, the images that remain are often regarded by visitors as no more than "... a curious reminder that Indians lived by the river long before Lewis and Clark paddled through in 1805" (Dreyfuss 1983, 69). The rock art also has a meaning and a value for Native Americans beyond tourism promotion as one of the last and most visible elements of their ancestors' cultural expression. The preservation of this rock art, and other cultural resources, is essential if we are to understand the past and its relationship to the present. 


\section{REFERENCES}

Aikens, Melvin C. 1986. Archaeology of Oregon. Oregon state office: U.S. Department of the Interior, Bureau of Land Management.

Allen, John E., Burns, M., and Sargent, S. C. 1986. Cataclysms on the Columbia. Portland, Oregon: Timber Press.

Allen, John E. 1984. The Magnificent Gateway. Forest Grove, Oregon: Timber Press.

Arden, H. 1989. Who owns the past? National Geographic 175(3): 376-392.

Bailey, Vernon. 1936. The mammals and lifezones of Oregon. U.S. Department of Agriculture, North American Fauna 55.

Baldwin, Edward M. 1981. Geology of Oregon. Dubuque, Iowa: Kenndall/Hunt Publishing Company.

Beals, Ralph L. 1971. Traffic in antiquities. American Antiquity 36(3): 374-375.

Beckham, Stephen Dow. 1988. Post-contact developments; exploration and settlement; and economic development in the Gorge. In Prehistory and History of the Columbia River Gorge National Scenic Area, Oregon and Washington, S. D. Beckham, R. Minor, K. A. Toepal, and J. Reese, pp. 126179. Eugene, Oregon: Heritage Research Associates Report No. 75.

Bell, Maurice M., Bell, M. M., and Kay, G. 1992. The impact of graffiti on neighborhoods and one community's response. In Vandalism: Research, prevention, and social policy, ed. H.H. Christensen, D.R. Johnson, and M.H. Brookes, pp. 143-151. Portland, Oregon: USDA Forest Service, Pacific Northwest Research Station, General Technical Report PNW-GTR-293.

Binford, L. 1980. Willow smoke and dogs' tails: Hunter-gatherer settlement systems and archaeological site formation. American Antiquity 45: 4-20. 
Blackburn, Fred M. 1992. Current programs in Southwest archaeology: Needs for community involvement. In Vandalism: Research, prevention, and social policy, ed. H.H. Christensen, D.R. Johnson, and M.H. Brookes, pp. 233-241. Portland, Oregon: USDA Forest Service, Pacific Northwest Research Station, General Technical Report PNW-GTR-293.

Blumenstyk, Goldie. 1992. State laws against vandalism of animal-research facilities provoke debate. The Chronicle of Higher Education 38(31): 26.

Brewer, Devon D., Christensen, H. H., and Miller, M. L. 1992. Hip hop graffiti writers: ethnographic observations on an urban youth subculture. In Vandalism: Research, prevention, and social policy, ed. H.H. Christensen, D.R. Johnson, and M.H. Brookes, pp. 13-39. Portland, Oregon: USDA Forest Service, Pacific Northwest Research Station, General Technical Report PNW-GTR-293.

Butzer, Karl. 1990. The Indian legacy in the American landscape. In The making of the American landscape, ed. Conzen, M.P., pp. 27-50. Boston: Unwin Hyman.

Carnett, Carol. 1991. Legal background of archaeological resources protection. Washington, D.C.: U. S. Department of the Interior, National Park Service, Technical Brief No. 11.

Cartwright, Chas. 1989. Graffiti removal strategies at two sites on the San Juan River: a cautionary tale. In Preserving our rock art heritage, ed. Crotty, Helen K, pp. 61-63. San Miguel, California: American Rock Art Site Research Association.

Chalmer, Bruce J. 1987. Understanding statistics. New York and Basel: Marcel Dekker, Inc.

Clewlow, C. W., Hallinan, P. S., and Ambro, R. D. 1971. A crisis in archaeology. American Antiquity 36(4): 472-473.

Columbia River Gorge Commission. 1988. Annual report. White Salmon, Washington: Columbia River Gorge Commission.

Davis, C., Russell, T., Osborn, J., and Shrader, D. 1992. Life beyond inventory: Cultural resource site protection on national forest lands in Oregon. In Vandalism: Research, prevention, and social policy, ed. H.H. Christensen, D.R. Johnson, and M. H. Brookes, pp. 195-207. Portland, Oregon: USDA Forest Service, Pacific Northwest Research Station, General Technical Report PNW-GRT-293. 
Denevan, William M. 1992. The pristine myth: The landscape of the Americas in 1492. Annals of the American Association of Geographers 82(3): 369-385.

Detling, LeRoy E. 1966. The flora of the Columbia River Gorge. Northwest Science, 40(4): 133-137.

Downer, A. 1992. Vandalizing and looting of archaeological sites on Indian lands: The Navajo reservation, a case study from the southwestern United States. In Vandalism: Research, prevention, and social policy, ed. H.H. Christensen, D.R. Johnson, and M.H. Brookes, pp. 209-219. Portland, Oregon: USDA Forest Service, Pacific Northwest Research Station, General Technical Report PNW-GTR-293.

Dreyfuss, Simeon. 1983. A prism of carved rock. The Pacific Northwest Quarterly 74(2): $69-76$.

Duncan, Mary Ann. 1979. Archaeological assessment of the proposed Horsethief Lake interpretive facility. Seattle: Office of Public Archaeology, Institute for Environmental Studies, University of Washington.

Dunford, Martin ed. 1989. The real guide: California and the West Coast. New York: Prentice Hall.

Freed, Robert. 1989. Personal communication.

Gale, Fay, and Jacobs, J. 1987. Tourists and the national estate. Canberra: Australian Government Publishing Service.

Gale, Fay. 1985. Monitoring visitor behaviour at rock art sites. Rock Art Research 2(2): 122-117.

General Accounting Office. 1987. Report to congressional requesters: Cultural resources: Problems protecting and preserving federal archaeological resources. Washington, D.C.: U.S. General Accounting Office RCED-88-3.

Gillespie, D.A. 1983. The practice of rock art conservation and site management in Kakadu National Park. In The rock art of Kakadu National Park. Canberra: Special publication 10, Australian National Parks and Wildlife Service.

Gorospe, Kathy. 1985. American Indian cultural resources: A preservation handbook. Salem, Oregon: Commission on Indian Services. 
Gottfredson, Gary D., and Gottfredson, D. C. 1985. Victimization in schools. New York: Plenum Press.

Gramann, James H., Christensen, H. H., and Vander Stoep, G. A. 1992. Indirect management to protect cultural and national resources: Research, ethics, and social policy. In Vandalism: Research, prevention, and social policy, ed. H.H. Christensen, D.R. Johnson, and M.H. Brookes, pp. 251-264. Portland, Oregon: USDA Forest Service, Pacific Northwest Research Station, General Technical Report PNW-GTR-293.

Harris, Glen. 1991. "Destructive recreation" on our public forests. American Forests 97(9-10): 37-44.

Higgins, Howard C. 1992. Rock art vandalism: causes and prevention. In Vandalism: Research, prevention, and social policy, ed. H.H. Christensen, D.R. Johnson, and M.H. Brookes, pp. 221-232. Portland, Oregon: USDA Forest Service, Pacific Northwest Research Station, General Technical Report PNW-GTR-293.

Hill, Beth, and Hill, R. 1974. Indian Petroglyphs of the Pacific Northwest. Saanichton, British Columbia, Canada: Hancock House Publishers.

Hitchman, Robert. 1985. Place Names of Washington. Tacoma, Washington: Washington State Historical Society.

Jennings, J. D. 1989. Prehistory of North America. Mountain View, California: Mayfield Publishing Company.

Keyser, James D. 1992. Indian rock art of the Columbia Plateau. Seattle and London: University of Washington Press.

Knudson, Ruth Ann. 1989. North America's threatened heritage. Archaeology 42(1): 71-76.

Landers, R. B. 1991. Is America allowing its past to be stolen? Editorial Research Reports no. 3, 34-46.

Loring, Malcolm J., and Loring, L. 1982. Pictographs and petroglyphs of the Oregon country, vol. 1. University of California at Los Angeles, Institute of Archaeology.

Lovell, W. G. 1992. "Heavy shadows and black night": Disease and depopulation in colonial South America. Annals of the American Association of Geographers 82(3): 426-443. 
Lyneis, Margaret M., Weide, D. L., Warren, E., and Ritter, E. W. Impacts: Damage to cultural resources in the California desert. Riverside, California: Bureau of Land Management.

Lynott, Robert E. 1966. Weather and climate of the Columbia Gorge. Northwest Science 40(4): 129-132.

Management plan for the Columbia River Gorge National Scenic Area. 1992. White Salmon, Washington, and Hood River, Oregon.

McAllister, Martin E. 1988. Areas and issues in future research on archaeological resource protection. In Tools to manage the past: Research priorities for cultural resource management in the Southwest: Symposium proceedings, Grand Canyon, Arizona, ed. Tainter, J. A, and Hamre, R. H., pp. 52-61. Fort Collins, Colorado: USDA Forest Service, Rocky Mountain Forest and Range Experiment Station, General Technical Report RM-164.

McClure, Richard H. 1978. An archaeological survey of petroglyph and pictograph sites in the state of Washington. Olympia, Washington: Evergreen State College.

- 1984. Rock art of The Dalles-Deschutes region: A chronological perspective. Unpublished master's thesis, Washington State University, Pullman, Washington.

McGinsey, Charles R. III. 1971. Archaeology and the law. American Antiquity 36(2): $125-126$.

Meyer, Karl E. 1973. The plundered past. New York: Antheneum.

Minor, R. 1988. History of archaeological investigations in the Columbia River Gorge; culture history; and the Columbia River Gorge in regional perspective. In Prehistory and History of the Columbia River Gorge National Scenic Area, Oregon and Washington, S. D. Beckham, R. Minor, K. A. Toepel, and J. Reese, pp. 31-80. Eugene, Oregon: Heritage Research Associates Report No. 75.

Moore, Elizabeth. 1992. A rock-solid devotion to pictographs. The Oregonian, mid-county section, Thursday May 21: 1 .

Morse, Kathleen S., and Anderson, R.S. 1988. Tourism in the Columbia River Gorge: A profile of visitors, accommodations, and economic impacts. Seattle, Washington: Washington Sea Grant Marine Advisory Services. 
Moulton, Gary E., ed. 1988. The Journals of the Lewis and Clark Expedition, July 28-November 1, 1805. Lincoln and London: University of Nebraska Press.

National Conference on Mass Transit Crime and Vandalism. 1981. National Conference on Mass Transit Crime and Vandalism. Albany, New York: New York Senate.

Nickens, Paul R., Larralde, S.L., and Tucker, G.C. 1981. A survey of vandalism to archaeological resources in southwestern Colorado. Denver, Colorado: U.S. Department of the Interior, Bureau of Land Management, Cultural Resource Series no. 11.

Pilles, Peter Jr. 1989. Public education and the management of rock art sites on the Coconino National Forest. In Preserving our rock art heritage, ed. by Crotty, H. K, pp. 23-34. San Miguel, California: American Rock Art Research Association.

Reese, Jo. 1988. Environmental setting. In Prehistory and History of the Columbia River Gorge National Scenic Area, Oregon and Washington, S. D. Beckham, R. Minor, K. A. Toepel, and J. Reese, pp. 5-29. Eugene, Oregon: Heritage Research Associates Report No.75.

Robertson, Carrie. 1990. Horsethief: secrets in stone. Columbia Country/ Hood River News, October 10: 1-3.

Roos, Hans-Edward. 1992. Vandalism as a symbolic act in "free zones". In Vandalism: Research, prevention, and social policy, ed. H.H. Christensen, D.R. Johnson, and M.H. Brookes, pp. 71-87. Portland, Oregon: USDA Forest Service, Pacific Northwest Research Station, General Technical Report PNW-GTR-293.

Rosenfeld, Andree. 1988. Rock art conservation in Australia. Canberra: Australian Government Publishing Service.

Rubin, Rick. 1989. Whom does she belong to? The Oregonian, Monday October 9: B7.

Silver, Constance. 1989. Rock art conservation: wish or reality? In Preserving our rock art heritage, ed. by Crotty, H. K. San Miguel, California: American Rock Art Research Association.

Society for American Archaeologists. 1990. Action for the '90s. Washington, D.C: Society for American Archaeologists. 
Strong, Emory. 1959. Stone Age on the Columbia River. Portland, Oregon: Binfords and Mort.

Sullivan, Sharon. n.d. Rock art site protection and management (lecture notes).

Sun, Marjorie. 1990. Hearing on lab vandalism. Science 247(4944): 801.

U.S. Department of the Interior. 1991. Pacific salmon management. Western Region, Portland, Oregon: U.S. Fish and Wildlife Service.

U.S. Army Corps of Engineers. 1988. The Dalles Lock and Dam (brochure). Portland District, Portland, Oregon.

USDA Forest Service. n.d. The Columbia River Gorge National Scenic Area (map). Pacific Northwest Region, Portland, Oregon.

Van D'Elden, Karl H. 1992. Gangs and graffiti: a Minneapolis perspective. In Vandalism: Research, prevention, and social policy, ed. H.H. Christensen, D.R. Johnson, and M.H. Brookes, pp. 163-172. Portland, Oregon: USDA Forest Service, Pacific Northwest Research Station, General Technical Report PNW-GTR-293.

Van Vliet, Willem. 1992. The cherry question or the role of social science research in designing against vandalism. In Vandalism: Research, prevention, and social policy, ed. H.H. Christensen, D.R. Johnson, and M.H. Brookes, pp. 31-47. Portland, Oregon: USDA Forest Service, Pacific Northwest Research Station, General Technical Report PNW-GTR-293.

West Publishing Co. 1989. West's revised code of Washington annotated. St. Paul, Minnesota: West Publishing Company.

Webster's Ninth New Collegiate Dictionary. 1989. Springfield, Massachusetts: Merriam-Webster Inc.

Wilke, Steve, Dalan, R., Wilde, J., James, K., Weaver, R., and Harvey, D. 1983. Cultural Resource Overview and Survey of Select Parcels in The Dalles Reservoir, Oregon and Washington. Report of Geo-Recon International to the U.S. Army Corps of Engineers, Portland District.

Wilkinson, Todd. 1991. Raiders of the parks. National Parks 65(9-10): 30-35.

Williams, Lance R. 1978. Vandalism to cultural resources of the Rocky Mountain West. USDA Forest Service, Southwest Region, Cultural Resources Report no. 21. 
Williams, Chuck. 1980. Bridge of the gods, mountain of fire: a return to the Columbia Gorge. New York: Friends of the Earth, and White Salmon, Washington: Elephant Mountain Arts.

Winter, Rosemary A. 1992. Metro awareness program: education, enforcement, and elimination. In Vandalism: Research, prevention, and social policy, ed. H.H. Christensen, D.R. Johnson, and M.H. Brookes, pp. 135-141. Portland, Oregon: USDA Forest Service, Pacific Northwest Research Station, General Technical Report PNW-GTR-293.

Woodward, John A. 1982. The ancient painted images of the Columbia Gorge. Ramona, California: Acoma Books. 


\section{APPENDIX A}

THE 15 ROCK ART SITES SELECTED FOR THE STUDY OF VANDALISM IN THE COLUMBIA RIVER GORGE NATIONAL SCENIC AREA AND THEIR RELATIONSHIP TO THE VARIABLES

AFFECTING VANDALISM 


\begin{tabular}{|c|c|c|c|c|c|c|c|c|c|c|c|}
\hline $\begin{array}{l}\text { variable } \\
\text { site }\end{array}$ & owner & size & vandalized & site type & $\begin{array}{l}\text { looting } \\
\text { near } \\
\text { the site }\end{array}$ & $\begin{array}{l}\text { public } \\
\text { awareness }\end{array}$ & $\begin{array}{l}\text { primary } \\
\text { access }\end{array}$ & $\begin{array}{l}\text { secondary } \\
\text { access }\end{array}$ & $\begin{array}{l}\text { distance } \\
\text { from } \\
\text { access }\end{array}$ & $\begin{array}{l}\text { dist. } \\
\text { from } \\
\text { boat }\end{array}$ & $\begin{array}{l}\text { dist. from } \\
\text { parking }\end{array}$ \\
\hline 45KL224 & private & small & yes & both & yes & no & RR tracks & river & $150 \mathrm{~m}$ & $1.4 \mathrm{~km}$ & $1.6 \mathrm{~km}$ \\
\hline 45KL 83 & private & small & no & petro. & no & no & RR & river & $100 \mathrm{~m}$ & $1.0 \mathrm{~km}$ & $1.4 \mathrm{~km}$ \\
\hline 45KLS8 & federal & large & yes & both & yes & yes & path & river & $1 \mathrm{~m}$ & $0.3 \mathrm{~km}$ & $0.5 \mathrm{~km}$ \\
\hline 45KL77 & private & large & yes & both & yes & no & combin. & river & $50 \mathrm{~m}$ & $4.2 \mathrm{~km}$ & $0.5 \mathrm{~km}$ \\
\hline $45 \mathrm{KL} 60$ & private & large & yes & pict. & yes & yes & $\begin{array}{l}\text { paved } \\
\text { road }\end{array}$ & none & $10 \mathrm{~m}$ & 0 & $.01 \mathrm{~km}$ \\
\hline 45KL69 & private & small & no & both & no & no & $\mathbf{R R}$ & river & $5 \mathrm{~m}$ & $6.9 \mathrm{~km}$ & $0.9 \mathrm{~km}$ \\
\hline $45 \mathrm{KL} / 223$ & private & small & no & pict. & yes & no & none & none & 0 & $1.3 \mathrm{~km}$ & $1.1 \mathrm{~km}$ \\
\hline $45 \mathrm{KL} 78$ & federal & med. & yes & pict. & no & yes & path & river & $1 \mathrm{~m}$ & $0.8 \mathrm{~km}$ & $0.3 \mathrm{~km}$ \\
\hline $45 \mathrm{KL} 96$ & private & med. & yes & petro. & no & no & $\begin{array}{l}\text { unpaved } \\
\text { road }\end{array}$ & none & $10 \mathrm{~m}$ & $3.8 \mathrm{~km}$ & $.01 \mathrm{~km}$ \\
\hline 45KL237 & federal & small & no & pict. & no & no & $\begin{array}{l}\text { gravel } \\
\text { road }\end{array}$ & RR & $5 \mathrm{~m}$ & 0 & $0.3 \mathrm{~km}$ \\
\hline 45KL65 & federal & small & no & petro. & no & no & paved road & none & $5 \mathrm{~m}$ & 0 & $0.1 \mathrm{~km}$ \\
\hline 45KL90 & private & med. & no & pict. & yes & no & RR & river & $150 \mathrm{~m}$ & $1.7 \mathrm{~km}$ & $2.2 \mathrm{~km}$ \\
\hline 45KLA69 & private & med. & no & pict. & no & no & $\mathbf{R R}$ & river & $50 \mathrm{~m}$ & $3.6 \mathrm{~km}$ & $.05 \mathrm{~km}$ \\
\hline $45 K L A 70$ & private & small & no & petro. & yes & no & $\mathbf{R R}$ & river & $125 \mathrm{~m}$ & $3.3 \mathrm{~km}$ & $0.1 \mathrm{~km}$ \\
\hline 45KL 80 & private & small & no & both & no & no & gravel road & none & $20 \mathrm{~m}$ & 0 & $.02 \mathrm{~km}$ \\
\hline
\end{tabular}




\begin{tabular}{|c|c|c|c|c|c|c|c|c|}
\hline $\begin{array}{l}\text { variable } \\
\text { sile }\end{array}$ & $\begin{array}{l}\text { degree of } \\
\text { vandalism }\end{array}$ & $\begin{array}{l}\text { nature of } \\
\text { vandalism }\end{array}$ & $\begin{array}{l}\text { kind of } \\
\text { vandalism }\end{array}$ & $\begin{array}{l}\text { distance to } \\
\text { The Dalles }\end{array}$ & $\begin{array}{l}\text { distance to The } \\
\text { Dalles Dam }\end{array}$ & $\begin{array}{l}\text { distance to } \\
\text { Wishram }\end{array}$ & $\begin{array}{l}\text { distance to } \\
\text { Horsethief Park }\end{array}$ & $\begin{array}{l}\text { graffiti near } \\
\text { the site }\end{array}$ \\
\hline $45 \mathrm{KL} 224$ & moderate & inadvertant & paint & $12.4 \mathrm{~km}$ & $10 \mathrm{~km}$ & $17.7 \mathrm{~km}$ & $1.8 \mathrm{~km}$ & no \\
\hline $45 \mathrm{KL} 83$ & none & none & none & $12 \mathrm{~km}$ & $9.8 \mathrm{~km}$ & $17.2 \mathrm{~km}$ & $1.4 \mathrm{~km}$ & yes \\
\hline $45 \mathrm{KL} 58$ & all & both & combination & $10.6 \mathrm{~km}$ & $8.8 \mathrm{~km}$ & $15.9 \mathrm{~km}$ & $\mathbf{0}$ & yes \\
\hline $45 \mathrm{KL77}$ & all & both & combination & $22 \mathrm{~km}$ & $19.6 \mathrm{~km}$ & $1.3 \mathrm{~km}$ & $16.4 \mathrm{~km}$ & yes \\
\hline 45KL60 & all & deliberate & paint & $28 \mathrm{~km}$ & $25.7 \mathrm{~km}$ & $0.8 \mathrm{~km}$ & $18.3 \mathrm{~km}$ & yes \\
\hline $45 \mathrm{KL} 69$ & none & none & none & $44.5 \mathrm{~km}$ & $42.2 \mathrm{~km}$ & $4.4 \mathrm{~km}$ & $37 \mathrm{~km}$ & no \\
\hline $45 \mathrm{KL} 223$ & none & none & none & $11.9 \mathrm{~km}$ & $2.5 \mathrm{~km}$ & $16.2 \mathrm{~km}$ & $1.1 \mathrm{~km}$ & no \\
\hline $45 \mathrm{KL} 78$ & moderate & inadvertant & touching & $11.1 \mathrm{~km}$ & $8.7 \mathrm{~km}$ & $12.6 \mathrm{~km}$ & $\mathbf{0}$ & no \\
\hline $45 \mathrm{KL} 96$ & minor & inadvertant & chalk & $14.1 \mathrm{~km}$ & $11.8 \mathrm{~km}$ & $8.7 \mathrm{~km}$ & $6.5 \mathrm{~km}$ & no \\
\hline 45LK237 & none & none & none & $3.7 \mathrm{~km}$ & $0.3 \mathrm{~km}$ & $21 \mathrm{~km}$ & $9 \mathrm{~km}$ & no \\
\hline 45KL65 & none & none & none & $2.8 \mathrm{~km}$ & $\mathbf{0}$ & $21 \mathrm{~km}$ & $9 \mathrm{~km}$ & no \\
\hline $45 \mathrm{KL} 90$ & none & none & none & $12.8 \mathrm{~km}$ & $10.7 \mathrm{~km}$ & $18.1 \mathrm{~km}$ & $2.2 \mathrm{~km}$ & no \\
\hline $45 \mathrm{KL} 469$ & none & none & none & $8.9 \mathrm{~km}$ & $6.6 \mathrm{~km}$ & $19.3 \mathrm{~km}$ & $4.3 \mathrm{~km}$ & no \\
\hline $45 \mathrm{KL} 470$ & none & none & none & $23.0 \mathrm{~km}$ & $20.8 \mathrm{~km}$ & $1.8 \mathrm{~km}$ & $15.7 \mathrm{~km}$ & yes \\
\hline 45KL80 & none & none & none & $23.5 \mathrm{~km}$ & $21.2 \mathrm{~km}$ & $2.2 \mathrm{~km}$ & $16.1 \mathrm{~km}$ & no \\
\hline
\end{tabular}


APPENDIX B

THE RESULTS OF THE STATISTICAL ANALYSIS 
T-TEST RESULTS FOR DISTANCE VARIABLES BETWEEN VANDALIZED

AND UNVANDALIZED SITES

\begin{tabular}{lccc} 
variable & T value & $\begin{array}{c}\text { degrees of } \\
\text { freedom }\end{array}$ & $p$ \\
\hline $\begin{array}{l}\text { distance from } \\
\text { access }\end{array}$ & -0.4572 & 13.0 & 0.6551 \\
$\begin{array}{l}\text { distance from } \\
\text { parking }\end{array}$ & -0.7299 & 13.0 & 0.4784 \\
$\begin{array}{l}\text { distance from } \\
\text { boat }\end{array}$ & -0.2042 & 13.0 & 0.8414 \\
$\begin{array}{l}\text { distance from The } \\
\text { Dalles }\end{array}$ & -0.2947 & 13.0 & 0.7729 \\
$\begin{array}{l}\text { distance from The } \\
\text { Dalles Dam }\end{array}$ & -0.2345 & 13.0 & 0.8182 \\
$\begin{array}{l}\text { distance from } \\
\text { Wishram }\end{array}$ & -0.9612 & 13.0 & 0.3540 \\
$\begin{array}{l}\text { distance from } \\
\text { Horsethief }\end{array}$ & -0.6394 & 13.0 & 0.5337 \\
& & &
\end{tabular}

T-TEST RESULTS FOR DISTANCE VARIABLES BETWEEN SITES WITH LOOTING IN THE VICINITY, AND SITES WITHOUT LOOTING IN THE VICINITY

\begin{tabular}{lccc} 
variable & T value & $\begin{array}{c}\text { degrees of } \\
\text { freedom }\end{array}$ & $p$ \\
\hline $\begin{array}{l}\text { distance from } \\
\text { access }\end{array}$ & 0.8346 & 13.0 & 0.4190 \\
$\begin{array}{l}\text { distance from } \\
\text { parking }\end{array}$ & 1.1011 & 13.0 & 0.2908 \\
$\begin{array}{l}\text { distance from } \\
\text { boat }\end{array}$ & -0.1727 & 13.0 & 0.8655 \\
$\begin{array}{l}\text { distance from The } \\
\text { Dalles }\end{array}$ & 0.1057 & 13.0 & 0.9174 \\
$\begin{array}{l}\text { distance from The } \\
\text { Dalles Dam }\end{array}$ & 0.2417 & 13.0 & 0.8128
\end{tabular}




\begin{tabular}{lccc} 
variable & T value & $\begin{array}{c}\text { degrees of } \\
\text { freedom }\end{array}$ & $p$ \\
\hline $\begin{array}{l}\text { distance from } \\
\text { Wishram }\end{array}$ & -0.7407 & 13.0 & 0.4721 \\
$\begin{array}{l}\text { distance from } \\
\text { Horsethief }\end{array}$ & -0.4616 & 13.0 & 0.6520
\end{tabular}

\section{T-TEST MEASUREMENT RESULTS FOR DISTANCE VARIABLES BETWEEN SITES WITH GRAFFITI IN THE VICINITY, AND SITES \\ WITHOUT GRAFFITI IN THE VICINITY}

\begin{tabular}{llcc} 
variable & T value & $\begin{array}{c}\text { degrees of } \\
\text { freedom }\end{array}$ & $p$ \\
\hline $\begin{array}{l}\text { distance from } \\
\text { access }\end{array}$ & 0.5507 & 13.0 & 0.5912 \\
$\begin{array}{l}\text { distance from } \\
\text { parking }\end{array}$ & -0.6276 & 13.0 & 0.5411 \\
$\begin{array}{l}\text { distance from } \\
\text { boat }\end{array}$ & -0.1638 & 13.0 & 0.8724 \\
$\begin{array}{l}\text { distance from The } \\
\text { Dalles }\end{array}$ & 1.0080 & 13.0 & 0.3319 \\
$\begin{array}{l}\text { distance from The } \\
\text { Dalles Dam }\end{array}$ & 0.9253 & 13.0 & 0.3717 \\
$\begin{array}{l}\text { distance from } \\
\text { Wishram }\end{array}$ & -1.6323 & 13.0 & 0.1266 \\
$\begin{array}{l}\text { distance from } \\
\text { Horsethief }\end{array}$ & 0.3112 & 13.0 & 0.7606
\end{tabular}




\section{$P$ VALUES OF FISHER'S EXACT TEST}

The seven statistically significant results

variables

vandalism and site size

vandalism and primary means of access

vandalism and public awareness

presence of graffiti and site size

degree of vandalism and site size

degree of vandalism and presence of graffiti

nature of vandalism and presence of graffiti $p$ .027

.0925

.044

.019

.05

.01

.01

Non-significant results

variables

vandalism and site ownership

looting at a site and site ownership

presence of graffiti and site ownership

degree of vandalism and site ownership

nature of vandalism and site ownership

kind of vandalism and site ownership

nature of vandalism and site size

looting at a site and site size

kind of vandalism and site size

degree of vandalism and primary means of access

nature of vandalism and primary means of access

kind of vandalism and primary means of access

\section{$p$}

1.0

0.569

1.0

1.0

1.0

0.733

1.0

0.125

0.467

1.0

1.0

1.0 
variables

looting at a site and primary means of access

presence of graffiti at a site and primary means of access

degree of vandalism and secondary means of access

nature of vandalism and secondary means of access

kind of vandalism and secondary means of access

vandalism and secondary means of access

looting at a site and secondary means of access

graffiti at a site and secondary means of access

degree of vandalism and public awareness

nature of vandalism and public awareness

kind of vandalism and public awareness

looting at a site and public awareness

presence of graffiti and public awareness

vandalism and site type

looting at a site and site type

presence of graffiti at a site and site type

degree of vandalism and site type

nature of vandalism and site type

kind of vandalism and site type

degree of vandalism and looting at a site

nature of vandalism and looting at a site

kind of vandalism and looting at a site

vandalism and looting at a site

kind of vandalism and the presence of graffiti at a site $p$

0.851

0.880

0.6

0.6

0.733

1.0

1.0

0.720

1.0

1.0

1.0

0.569

0.242

0.660

0.119

0.517

0.8

0.8

0.467

0.2

0.6

0.2

0.315

0.6 